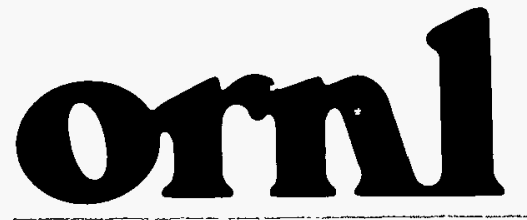

OAK RIDGE NATIONAL LABORATORY

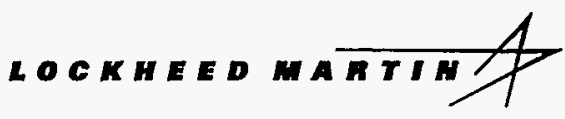

MANAGED AND OPERATED BY LOCKHEED MARTIN ENERGY RESEARCH CORPORATION FOR THE UNTED STATES DEPARTUENT OF ENERGY

\title{
A COASTAL HAZARDS DATA BASE FOR THE U.S. WEST COAST
}

\author{
Vivien M. Gornitz* \\ Tammy W. Beaty \\ Richard C. Daniels ${ }^{\dagger}$
}

\footnotetext{
*Center for Climate Systems Research, Columbia University

'Energy, Environment and Resources Center, The University of Tennesee
} 
This report has been reproduced directly from the best available copy.

Available to DOE and DOE contractors from the Office of Scientific and Technical Information, P.O. Box 62, Oak Ridge. TN 37831; prices available from (423) 576-8401, FTS 626-8401.

Available to the public from the National Technical Information Service, U.S. Department of Commerce, 5285 Port Royal Rd., Springfield, VA 22161.

This report was prepared as an account of work sponsored by an agency of the United States Government. Neither the United States Government nor any agency thereof, nor any of their employees, makes any warrenty, express or implied, or assumes any legal liability or responsibility for the accuracy, completeness, or usefulness of any information, apparatus, product, or process disclosed, or represents that its use would not intringe privately owned rights. Reference herein to any specific commercial product, process, or service by trade name, trademark, manufacturer, or otherwise, does not necessarily constitute or imply its endorsement, recommendation, or favoring by the United States Government or any agency thereof. The views and opinions of authors expressed herein do not necessarily state or reflect those of the United States Government or any agency thereof. 


\section{DISCLAIMER}

Portions of this document may be illegible electronic image products. Images are produced from the best available original document. 
ORNL/CDIAC- 81

NDP-043C

\title{
A COASTAL HAZARDS DATA BASE FOR THE U.S. WEST COAST
}

\author{
Contributed by \\ - Vivien M. Gornitz \\ Center for Climate Systems Research, Columbia University \\ Goddard Institute for Space Studies \\ National Aeronautics and Space Administration \\ New York, New York \\ Tammy W. Beaty \\ Carbon Dioxide Information Analysis Center \\ Environmental Sciences Division \\ Oak Ridge National Laboratory \\ Oak Ridge, Tennessee. \\ Richard C. Daniels ${ }^{1}$ \\ Energy, Environment and Resources Center \\ The University of Tennessee \\ Knoxville, Tennessee \\ Environmental Sciences Division \\ Publication No. 4590 \\ Date Published: December 1997 \\ Prepared for the \\ Environmental Sciences Division \\ Office of Biological and Environmental Research \\ U.S. Department of Energy \\ Budget Activity Number KP 1204010 \\ Prepared by the \\ Carbon Dioxide Information Analysis Center \\ OAK RIDGE NATIONAL LABORATORY \\ Oak Ridge, Tennessee 37831-6335 \\ managed by \\ LOCKHEED MARTIN ENERGY RESEARCH CORP. \\ for the \\ U.S. DEPARTMENT OF ENERGY \\ under contract DE-AC05-96OR22464
}




\section{TABLE OF CONTENTS}

\section{Page}

LIST OF FIGURES $\ldots \ldots \ldots \ldots \ldots \ldots \ldots \ldots \ldots \ldots \ldots$

LIST OF TABLES $\ldots \ldots \ldots \ldots \ldots \ldots \ldots \ldots \ldots \ldots \ldots \ldots \ldots$ vii

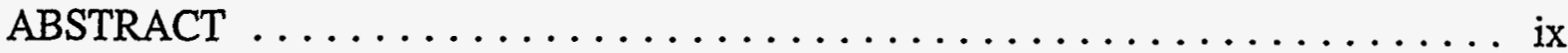

PART 1: INFORMATION ABOUT THE DATA PACKAGE $\ldots \ldots \ldots \ldots \ldots \ldots 1$

1. Name of the Numeric Data Package $\ldots \ldots \ldots \ldots \ldots \ldots \ldots \ldots$

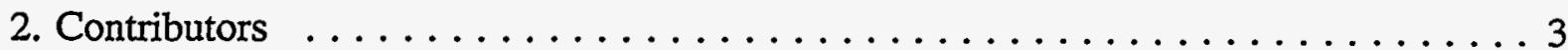

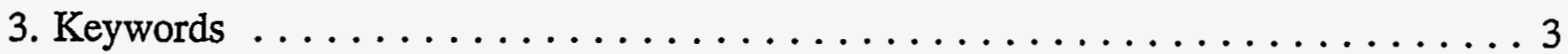

4. Background Information $\ldots \ldots \ldots \ldots \ldots \ldots \ldots \ldots \ldots \ldots \ldots$

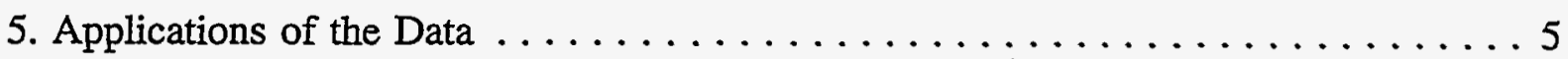

6. Definition of Standard Terms and Concepts $\ldots \ldots \ldots \ldots \ldots \ldots$

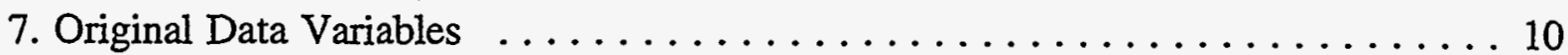

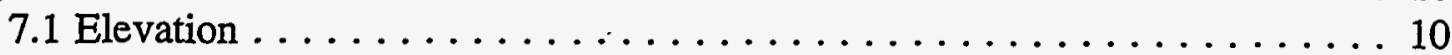

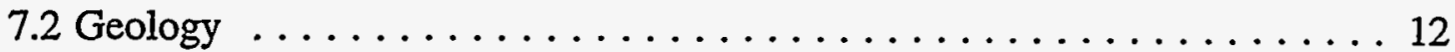

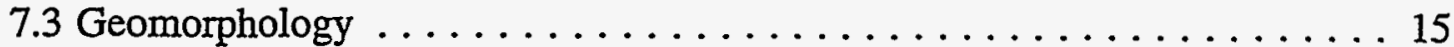

7.4 Sea-Level Trends . . . . . . . . . . . . . . . . . . . . 18

7.5 Horizontal Shoreline Displacement (Erosion/Accretion) $\ldots \ldots \ldots \ldots .21$

7.6 Tidal Ranges . . . . . . . . . . . . . . . . . . . 23

7.7 Wave Heights . . . . . . . . . . . . . . . . . . 24

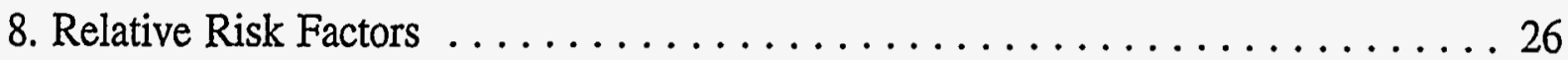

9. The Coastal Vulnerability Index $\ldots \ldots \ldots \ldots \ldots \ldots \ldots \ldots \ldots \ldots \ldots \ldots$

10. Limitations and Restrictions of the Data $\ldots \ldots \ldots \ldots \ldots \ldots \ldots \ldots \ldots \ldots$

11. Data Checks Performed by CDIAC $\ldots \ldots \ldots \ldots \ldots \ldots \ldots \ldots \ldots \ldots \ldots \ldots$

12. How to Obtain the Data Package $\ldots \ldots \ldots \ldots \ldots \ldots \ldots \ldots \ldots \ldots \ldots \ldots \ldots \ldots \ldots$ 
13. References and Data Sources ... . . . . . . . . . . . . . . . 34

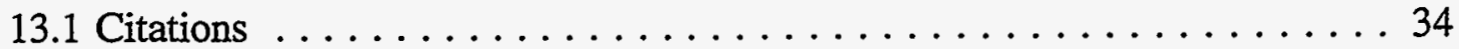

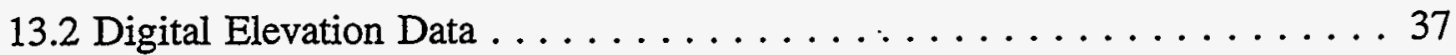

13.3 Geology Maps ........................... 37

13.4 Topographic Maps ........................... 38

PART 2: INFORMATION ABOUT THE COMPUTERIZED DATA FILES . . . . 41

14. Contents of the Computerized Data Files $\ldots \ldots \ldots \ldots \ldots \ldots \ldots$

15. Contents of the Descriptive File $\ldots \ldots \ldots \ldots \ldots \ldots \ldots \ldots \ldots \ldots$

16. Listing of the FORTRAN Data Retrieval Programs $\ldots \ldots \ldots \ldots \ldots$

17. Listing of the $\mathrm{SAS}^{\mathrm{TM}}$ Data Retrieval Programs $\ldots \ldots \ldots \ldots \ldots \ldots \ldots$

18. Partial Listings of the Flat ASCI Data Files $\ldots \ldots \ldots \ldots \ldots \ldots \ldots \ldots$

19. Verification of Data Transport: Flat ASCII Data Files $\ldots \ldots \ldots \ldots \ldots$

20. Verification of Data Transport: Arc/Info ${ }^{\mathrm{TM}}$ Export Files $\ldots \ldots \ldots \ldots \ldots 78$

APPENDICES . . . . . . . . . . . . . . . . . . . . . 79

APPENDIX A: THE DATA GROUPS, A QUICK REFERENCE . . . . . A - 1

APPENDIX B: GLOSSARY OF TERMS . . . . . . . . . . . B - 1

Glossary of Terms Used in the Geologic Classification B - 3

Glossary of Terms Used in the Geomorphic Classification B - 5

References $\quad$ B -7

APPENDIX C: DATA LISTING OF GEOLOGIC AND GEOMORPHIC

DATA ............................ -1

Geologic Data · C -4

Geomorphologic Data $\quad$ C -14

APPENDIX D: Geologic Trends Supplement .............. D - 1

Correction of relative sea-level trends for vertical land

motions, U.S. West Coast, by V. Gornitz, 1996. . . . . . . . D D 3

APPENDIX E: REPRINT OF PERTINENT LITERATURE ......... E - 1

The Development of a Coastal Risk Assessment Data Base

for the U.S. Southeast, by Gornitz, V., R. C. Daniels,

T. W. White, and K. R. Birdwell. 1994. . . . . . . . . . E - 3 


\section{LIST OF FIGURES}

Figure

Page

Fig. 1.

The U.S. West Coast. . . . . . . . . . . . . . . . 5

Fig. 2a. Grid cells $\left(0.25^{\circ}\right.$ by $\left.0.25^{\circ}\right)$ and line segments $(1: 2,000,000)$ used in the raster (ASCI) and vector (Arc/Info ${ }^{\mathrm{TM}}$ ) files for Washington and northern Oregon. The value shown within each cell is the grid cell identification number. . . . . . . . . . . . . . . . . . 7

Fig. 2b. Grid cells $\left(0.25^{\circ}\right.$ by $\left.0.25^{\circ}\right)$ and line segments $(1: 2,000,000)$ used in the raster (ASCII) and vector (Arc/Info ${ }^{\mathrm{TM}}$ ) files for southern Oregon and northern California. The value shown within each cell is the grid cell identification number. . . . . . . . . . . . . . . . 8

Fig. 2c. Grid cells $\left(0.25^{\circ}\right.$ by $\left.0.25^{\circ}\right)$ and line segments $(1: 2,000,000)$ used in the raster (ASCII) and vector (Arc//nfo ${ }^{\mathrm{TM}}$ ) files for southern California. The value shown within each cell is the grid cell identification number. . . . . 9

Fig. 3. The original NGDC elevation data set and the corrected coastal grid cells with calculated mean elevation values (i.e., values of $0 \mathrm{~m}$ ) used in this NDP. ................................ 11

Fig. 4. Example of how the geologic data were transferred from the $1: 2,000,000$ digitized coastline map to the $0.25^{\circ}$ by $0.25^{\circ}$ grid cells used in this data base. ............................. 14

Fig. 5. Locations of the 16 sea-level gauge stations used in this NDP. . . . . . 19

Fig. 6. Example of how the shoreline displacement data were transferred to the $0.25^{\circ}$ grid cells used in this NDP. . . . . . . . . . . . 22

Fig. 7 Example of how the wave height data were transferred to the $0.25^{\circ}$ by $0.25^{\circ}$ grid cells used in this NDP. . . . . . . . . 25

Fig. 8 Example of how the Coastal Vulnerability Index $\left(\mathrm{CVI}_{5}\right)$ may be used to identify high-risk coastlines. . . . . . . . . . . . . 30 
- 


\section{LIST OF TABLES}

Table

Page

Table 1. Geologic classification codes assigned to the coastal geology variable. . 12

Table 2. Geomorphology classification codes assigned to the coastal geomorphology variable. . . . . . . . . . . . . . . . . 16

Table 3. Relative sea-level trends, U.S. West Coast, mm/year. . . . . . . . . 18

Table 4. Assignment of relative risk factors for elevation, shoreline displacement, local subsidence trend, tidal range, and wave height. . . . . . . . . 26

Table 5. Assignment of relative risk factors for geology. . . . . . . . . . 27

Table 6. Assignment of relative risk factors for geomorphology. . . . . . . . . 27

Table 7. Sensitivity of different Coastal Vulnerability Indices to changes in risk class from high to low assignments for one to three variables. . . . 29

Table 8. List and description of the NDP-043C data files. . . . . . . . . . 43

Table 9. Variable formats for WCGRID.ASC (File 5). . . . . . . . . . . . 49

Table $10 \quad$ Variable formats for WCRISK.ASC (File 9). . . . . . . . . . . . 54

Table 11. Variable formats for WCLINE.ASC (File 13). . . . . . . . . . 56

Table 12. ' Variable formats for WCPOINT.ASC (File 17). . . . . . . . . . . 61

Table 13. Sample of the vector format used for WCOAST.ASC (File 21). . . . . 65

Table 14. Statistical characteristics of the numeric variables in WCGRID.ASC (File 5). ........................... 75

Table 15. Statistical characteristics of the numeric variables in WCRISK.ASC (File 9) .......................... 76

Table 16. Statistical characteristics of the numeric variables in WCLINE.ASC (File 13). .......................... 76

Table 17. Statistical characteristics of the numeric variables in WCPOINT.ASC

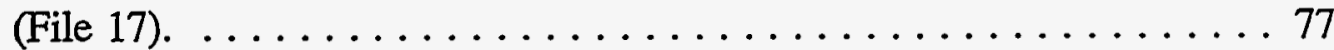

Table 18. Characteristics and size, in bytes and 512-byte blocks, of WCOAST.ASC

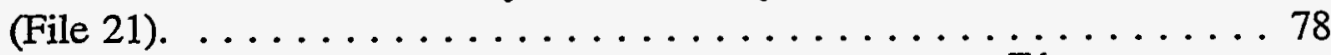

Table 19. File size and number of attribute records in each Arc/Info ${ }^{\mathrm{TM}}$ export file.

Table C1. Geologic data by grid cell. .................. C 4

Table C2. Geomorphic data by grid cell. ................ -14 



\begin{abstract}
GORNITZ, V. M., T. W. BEATY, and R. C. DANIELS. 1997. A Coastal Hazards Data Base for the U.S. West Coast. ORNL/CDIAC-81, NDP-043C, Oak Ridge National Laboratory, Oak Ridge, Tennessee. $162 \mathrm{pp}$.
\end{abstract}

This document describes the contents of a digital data base that may be used to identify coastlines along the U.S. West Coast that are at risk to sea-level rise. This data base integrates point, line, and polygon data for the U.S. West Coast into $0.25^{\circ}$ latitude by $0.25^{\circ}$ longitude grid cells and into 1:2,000,000 digitized line segments that can be used by raster or vector geographic information systems (GIS) as well as by non-GIS data bases. Each coastal grid cell and line segment contains data variables from the following seven data sets: elevation, geology, geomorphology, sea-level trends, shoreline displacement (erosion/accretion), tidal ranges, and wave heights. One variable from each data set was classified according to its susceptibility to sea-level rise and/or erosion to form 7 relative risk variables. These risk variables range in value from 1 to 5 and may be used to calculate a Coastal Vulnerability Index (CVI). Algorithms used to calculate several CVIs are listed within this text. The data for these 29 variables (i.e., the 22 original variables and 7 risk variables) are available as:

(1) Gridded polygon data for the 22 original data variables. Data include elevation, geology, geomorphology, sea-level trends, shoreline displacement (erosion/accretion), tidal ranges, and wave heights.

(2) Gridded polygon data for the seven classified risk variables. The risk variables are classified versions of: mean coastal elevation, geology, geomorphology, local subsidence trend, mean shoreline displacement, maximum tidal range, and maximum significant wave height.

(3) 1:2,000,000 line segment data containing the 29 data variables (i.e., the 22 original data variables and the 7 classified risk variables).

(4) Supplemental point data for the stations used in calculating the sea-level trend and tidal range data sets.

(5) Supplemental line segment data containing a 1:2,000,000 digitized coastline of the U.S. West Coast.

These data are available as a Numeric Data Package (NDP) from the Carbon Dioxide Information Analysis Center (CDIAC). The NDP consists of this document and machine-readable files available on 8-mm tapes, quarter inch tape cartridges, IBM-formatted high-density floppy diskettes, and CD-ROM. These files are also available through the Internet using the File Transfer Protocol (FTP) from CDIAC's anonymous FTP area which can be accessed directly (cdiac.esd.ornl.gov) or through the World Wide Web (WWW) at http://cdiac.esd.ornl.gov/. This document provides sample listings of the data and detailed descriptions of the file formats; offers FORTRAN and $S A S^{\mathrm{TM}}$ retrieval program listings; describes the methods used in calculating each variable; discusses the sources, restrictions, and limitations of the data; provides five $\mathrm{Arc} / \mathrm{Info}^{\mathrm{TM}}$ export coverages and flat ASCII data files containing these data; and reprints pertinent literature.

SAS ${ }^{\mathrm{TM}}$ is a registered trademark of the SAS Institute, Inc., Cary, NC 27511-8000.

Arc/Info ${ }^{\text {TM }}$ is a registered trademark of the Environmental Systems Research Institute (ESRI), Inc., Redlands, CA 92372. 
PART 1: INFORMATION ABOUT THE DATA PACKAGE 


\section{Name of the Numeric Data Package}

A COASTAL HAZARDS DATA BASE FOR THE U.S. WEST 'COAST

\section{Contributors}

\section{Vivien M. Gornitz}

Center for Climate Systems Research

Columbia University

Goddard Institute for Space Studies

National Aeronautics and Space Administration

2280 Broadway

New York, NY 10025

\section{Tammy W. Beaty}

Carbon Dioxide Information Analysis Center

Environmental Sciences Division

Oak Ridge National Laboratory

P.O. Box 2008

Oak Ridge, TN 37831-6407

\section{Richard C. Daniels}

Energy, Environment and Resources Center

The University of Tennessee

Knoxville, Tennessee

Current Address:

Shorelands and Water Resources Program

Water Division, Department of Ecology

P.O. Box 47690

Olympia, WA 98504

\section{Keywords}

Coastal hazards; risk assessment; sea-level trends; sea-level rise; elevation; geology;

geomorphology; coastal landform; subsidence; erosion; accretion; tidal range; wave height.

\section{Background Information}

Data records accumulated over the past 100 years indicate that sea levels have been rising at a rate of 1-2 mm/yr due to the thermal expansion of the ocean and the increased melting of continental and alpine glaciers (Houghton et al. 1996). During the next 100 years, increasing atmospheric concentrations of $\mathrm{CO}_{2}$ and other greenhouse gases may lead to an increase in the world's mean 
surface air temperature of $1-5^{\circ} \mathrm{C}$ unless emission levels are reduced (Houghton et al. 1996 and Warrick et al. 1993). Such warming could further enhance the thermal expansion of the ocean and the melting of continental and alpine glaciers.

Changes in climate will affect the coastal zone. Short-term climatic variations have been shown to affect the maximum intensity and frequency of storms (Emanuel 1988) and can cause an acceleration or deceleration in shoreline erosion rates (Dolan et al. 1988). Unanticipated changes in these factors can result in unnecessary loss of life and/or property (Case and Mayfield, 1990). This database may be used to identify areas that are, or could be, at risk to erosion or inundation from change in climate or sea-level rise based on information on the past and current state of the coast.

In 1987, the U.S. Department of Energy's Atmospheric and Climate Research Division funded Dr. Vivien M. Gornitz (Goddard Institute for Space Studies) and the Carbon Dioxide Information and Analysis Research Program (CDIARP), Resource Analysis Project, at Oak Ridge National Laboratory (ORNL) in Oak Ridge, Tennessee, to develop a Coastal Hazards Data Base to provide information on the past and current state of world coastlines. The data base contains information on relative sea-level trends, elevation, vertical land movements, horizontal displacement (erosion/accretion), coastal geomorphology, and geology (Gornitz and Kanciruk 1989). CDIAC has published the following three volume series of NDPs for the continental United States: $A$ Coastal Hazards Data Base for the U.S. East Coast, ORNL/CDIAC-45, NDP-043A; followed by $A$ Coastal Hazards Data Base for the U.S. Gulf Coast, ORNL/CDIAC-60, NDP-043B; and finally this NDP for the U.S. West Coast (ORNL/CDIAC-81, NDP-043C) (Gornitz and White 1992, Gornitz and White 1994, and this volume). A complementary coastal data base for Canada has been developed by the Geological Survey of Canada and is described in Shaw et al. (1994).

The data in this NDP may be used to calculate the relative vulnerabilities of different areas along the U.S. West Coast to projected increases in air and sea surface temperatures and sea-level change. This data base may also be combined with the two previous coastal hazard NDPs (NDP043A and NDP-043B) to obtain a data base that covers the entire conterminous United States. This information will be useful to researchers, government planning agencies, the private sector, and educational institutions interested in determining the present and future vulnerabilities of coastal zones to erosion and sea-level-rise.

The data base described here comprises data extracted from a variety of sources, including publications of the National Oceanic and Atmospheric Administration (NOAA), the U.S. Army Corp of Engineers, the U.S. Geological Survey (USGS), universities, and other federal and state agencies. These data varied in scale and format. To facilitate data analysis, these data have been referenced to a grid of $0.25^{\circ}$ latitude by $0.25^{\circ}$ longitude and to a $1: 2,000,000$ digitized coastline of the U.S. West. This NDP defines the U.S. West Coast as extending from the California-Mexican border to the Washington-Canadian border (Fig. 1). 
Fig. 1. The U.S. West Coast.

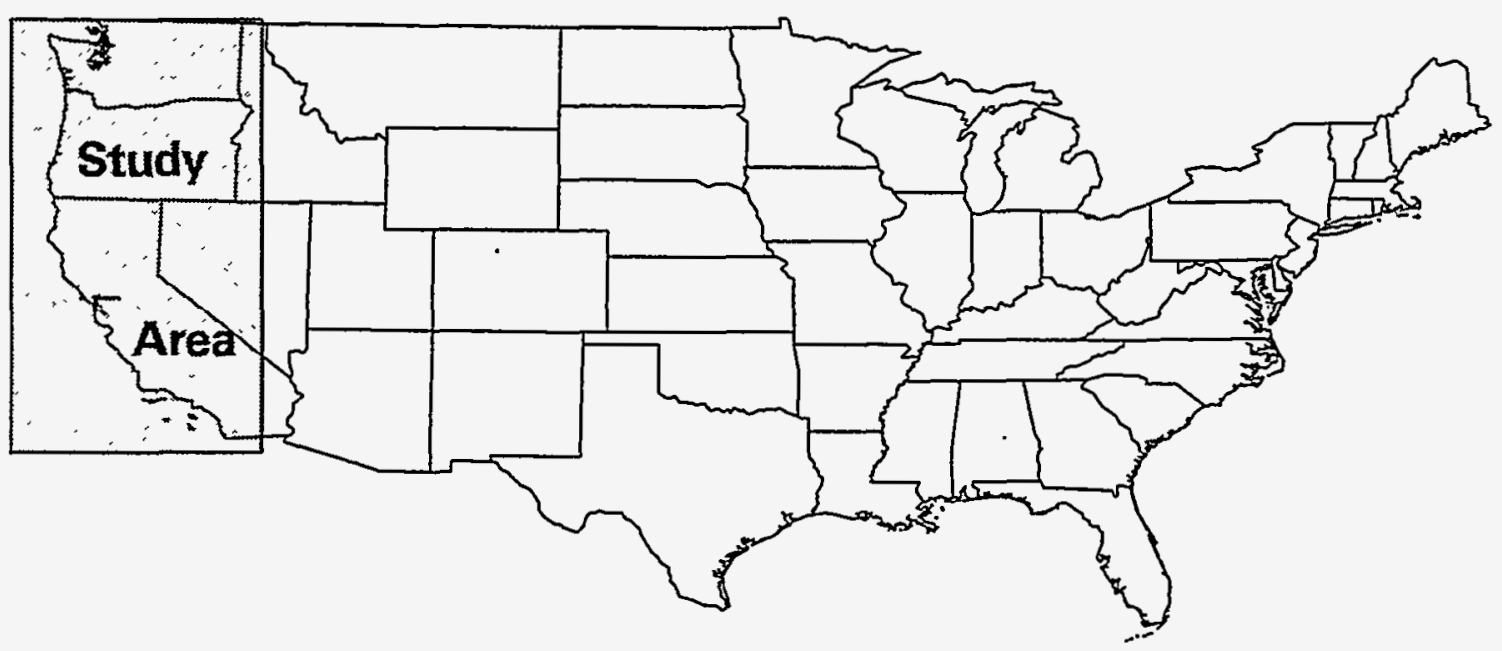

\section{Applications of the Data}

This coastal hazards data base contains information on elevation, bedrock geology, geomorphology (coastal landform), sea-level trends, horizontal shoreline displacement (erosion), tidal ranges, and wave heights. These data variables were selected for inclusion in this data base because of the roles they play in determining the vulnerability of coastal areas to variations in sea level and longterm erosion.

The 29 data variables in this data base effectively measure two basic risk factors, erosion and inundation. The erosion risk was determined on the basis of historical shoreline displacement, resistance to erosion (geology, geomorphology), and ocean-forcing factors (tidal ranges and wave heights). The inundation risk was estimated on the basis of sea-level trends and elevation data.

This data base and the coastal vulnerability indices (CVIs) that may be calculated with it may be used to identify coastal zones that are at risk from coastal erosion or possible changes in relative sea level. 


\section{Definition of Standard Terms and Concepts}

The data variables within this data base have been placed into five data groups (i.e., three primary groups and two supplemental data groups). A quick reference listing of these data groups and variables is contained in Appendix A. The following terminology is used throughout this documentation.

Data variable-A single, discrete data item within a data group or data set (e.g., data set=elevation, data variable $=$ mean elevation).

System variable-A numeric variable that geographically identifies data variables within a data group.

Data set-A collection of data variables that have been derived from a single data source, such as the mean and maximum elevation variables.

Data group-A collection of data variables that have been placed into a single Arc/Info ${ }^{\mathrm{TM}}$ export file and a comparable flat ASCII file.

Data base-All data groups within this NDP.

Original data variables-The 22 data variables from the seven data sets presented within this NDP [i.e., mean, maximum, and minimum elevation, and the number of $5^{\prime}$ National Geophysical Data Center (NGDC) grid cells used in deriving the data values; geology; geomorphology; relative sea level trend, long-term geologic trend, corrected sea-level trend, local subsidence trend, and years of record of the gauge stations used in calculating these values; mean, maximum, and minimum shoreline displacement, and the number of $3^{\prime}, 7.5^{\prime}$, or $15^{\prime}$ grid cells used in deriving the data values; mean and maximum tidal range, mean tide level, and the number of tide gauge stations used in calculating these variables; the 20-year mean wave height, maximum significant wave height and its standard deviation].

Relative risk variables-The 7 classified risk variables derived from each of the following: mean coastal elevation, geology, geomorphology, local subsidence trend, mean shoreline displacement, mean tidal range, and maximum significant wave height.

Each of the five data groups within this NDP is stored as an exported Arc/Info ${ }^{\mathrm{TM}}$ coverage and as a flat ASCII file.

The first two primary data groups are referenced to a $0.25^{\circ}$ latitude by $0.25^{\circ}$ longitude grid and stored as exported Arc/Info ${ }^{\mathrm{TM}}$ polygon coverages and as flat ASCII files. The first group contains the original 22 data variables, while the second contains the 7 relative risk data variables. The grid system used covers the West Coast of the U.S. and is outlined by the following coordinates: $126^{\circ} \mathrm{W}, 32^{\circ} \mathrm{N} ; 126^{\circ} \mathrm{W}, 49^{\circ} \mathrm{N} ; 116^{\circ} \mathrm{W}, 49^{\circ} \mathrm{N}$; and $116^{\circ} \mathrm{W}, 32^{\circ} \mathrm{N}$. The grid origin (i.e., grid cell number 1) is at $126^{\circ} \mathrm{W}, 32^{\circ} \mathrm{N}$, and cell identification numbers increase from left to right, bottom to top (Fig. 2a, 2b, and 2c). 
Fig. 2a. Grid cells $\left(0.25^{\circ}\right.$ by $\left.0.25^{\circ}\right)$ and line segments $(1: 2,000,000)$ used in the raster (ASCI) and vector (Arc/Info ${ }^{\mathrm{TM}}$ ) files for Washington and northern Oregon. The value shown within each cell is the grid cell identification number.

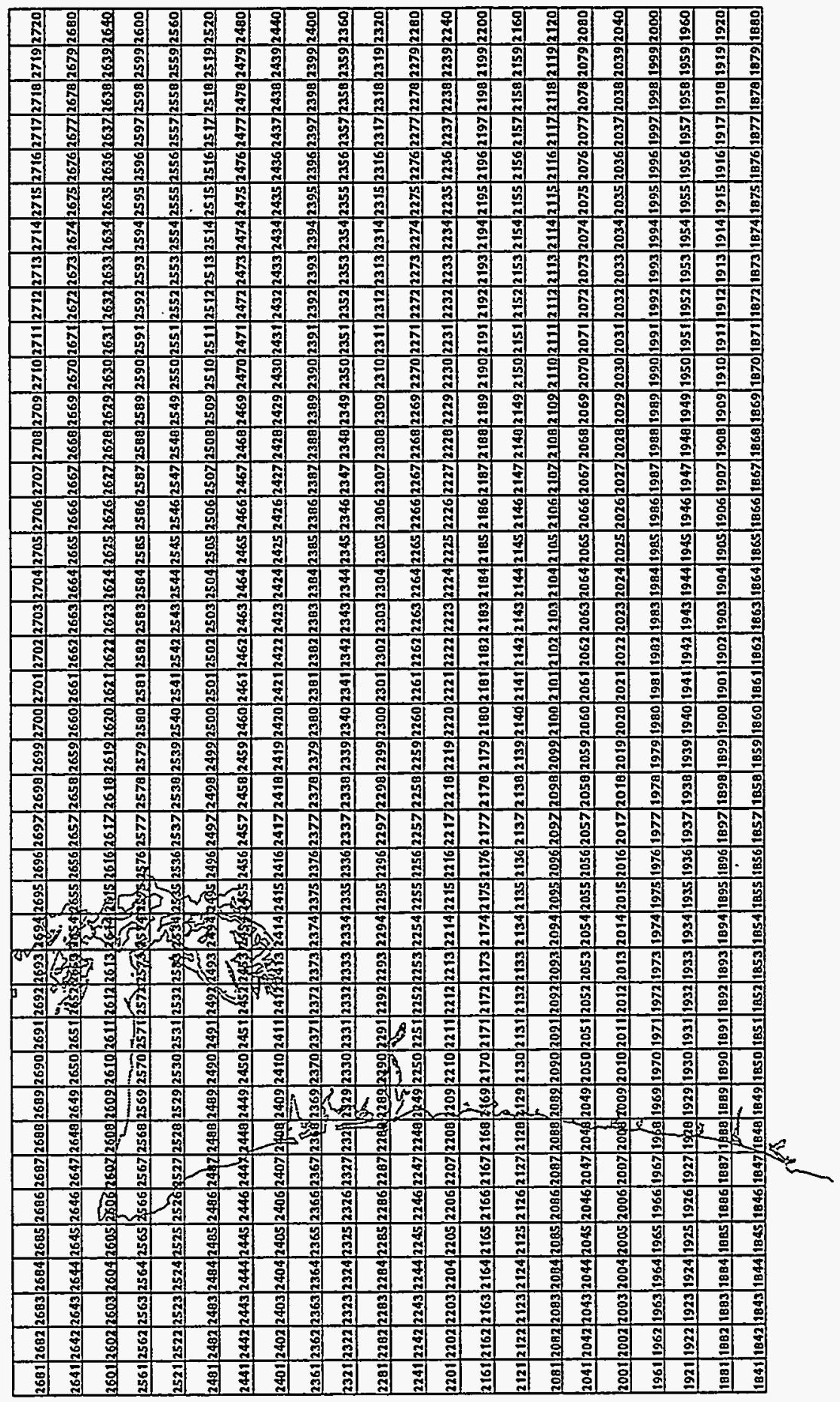


Fig. 2b. Grid cells $\left(0.25^{\circ}\right.$ by $\left.0.25^{\circ}\right)$ and line segments $(1: 2,000,000)$ used in the raster (ASCII) and vector (Arc/Info ${ }^{\mathrm{TM}}$ ) files for southern Oregon and northern California. The value shown within each cell is the grid cell identification number.

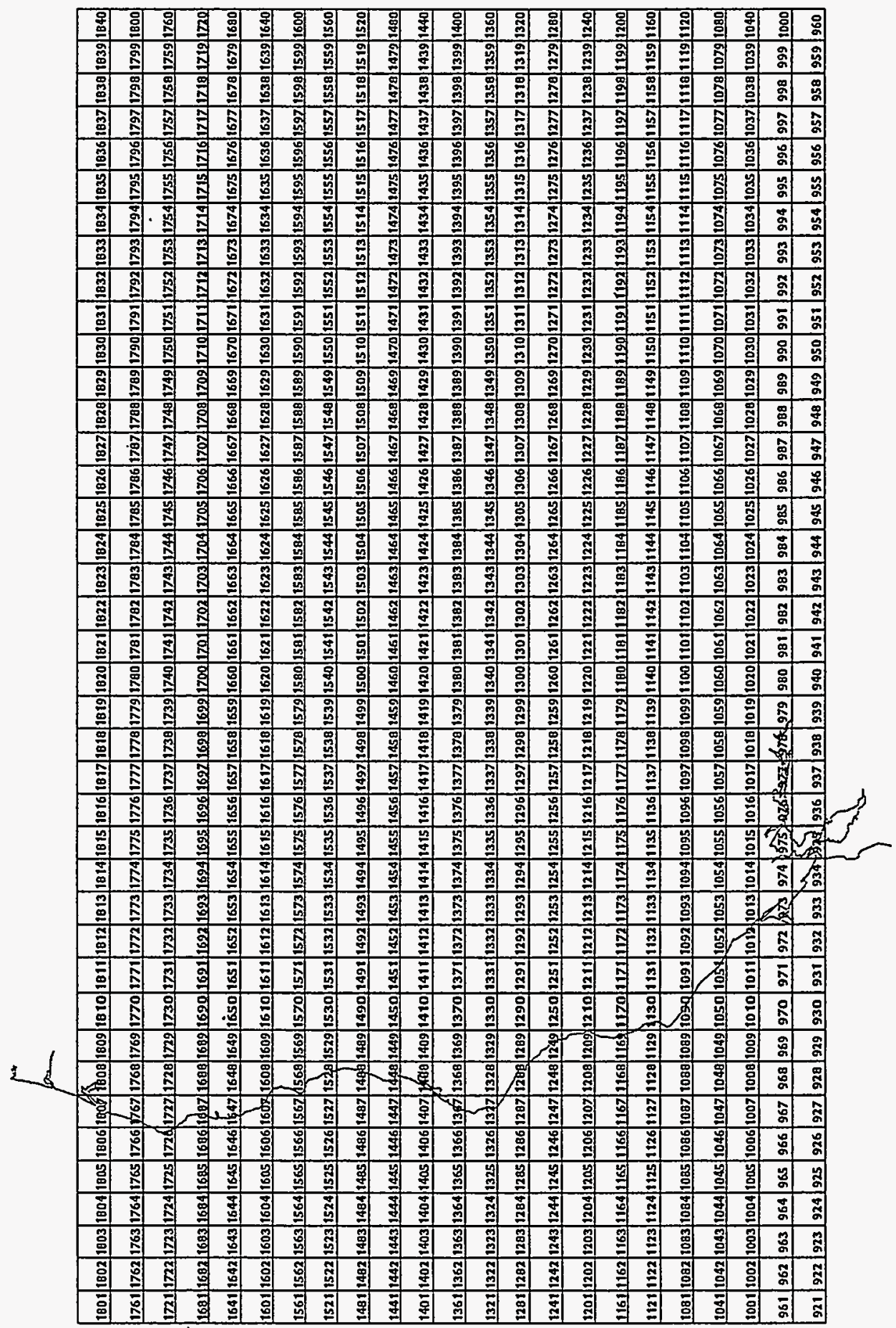




\section{A}

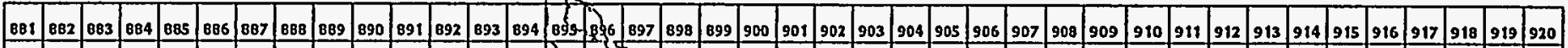

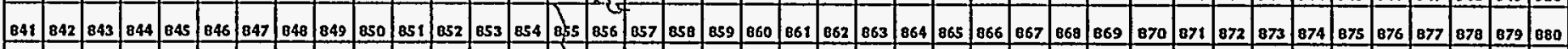

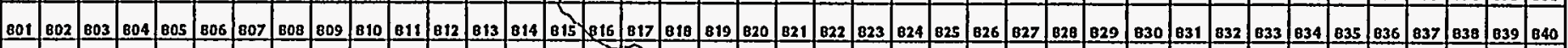

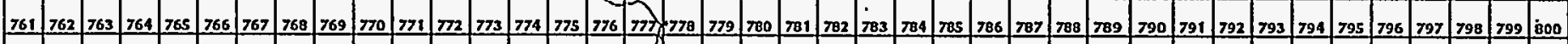

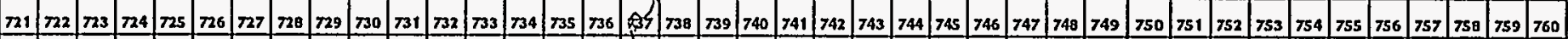

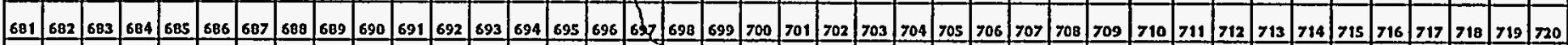

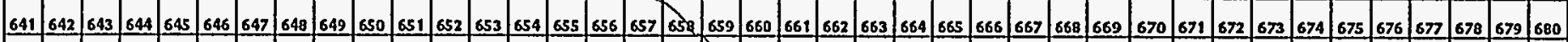

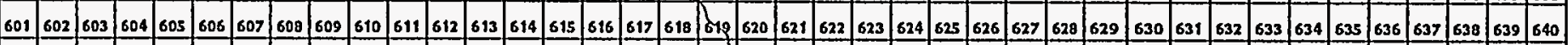

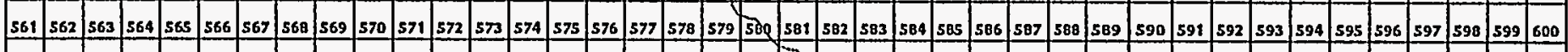

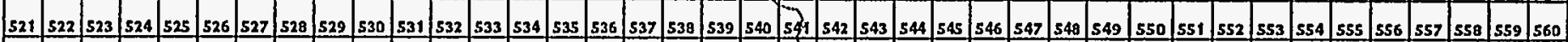

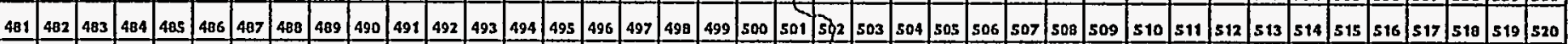

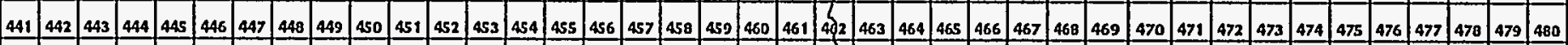

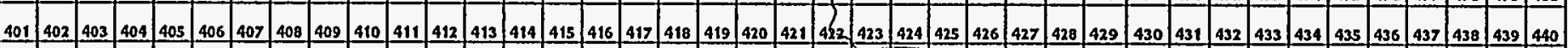

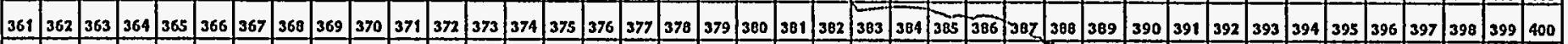

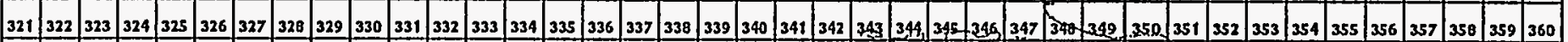

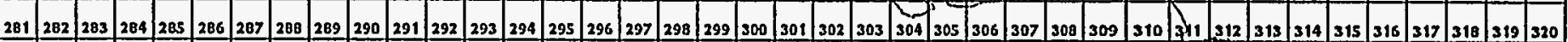

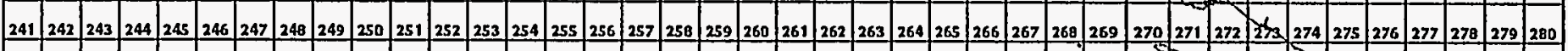

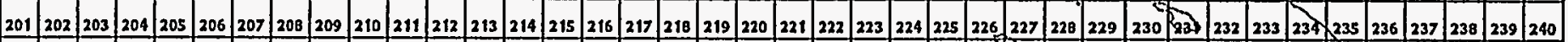

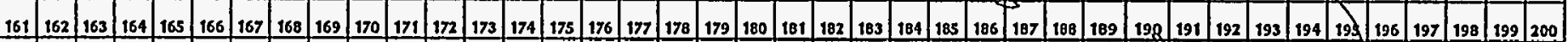

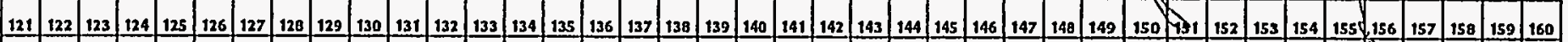

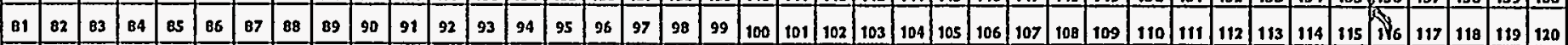

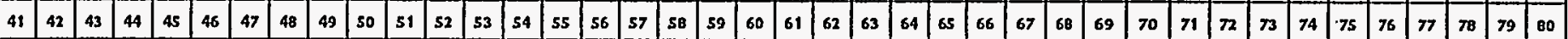

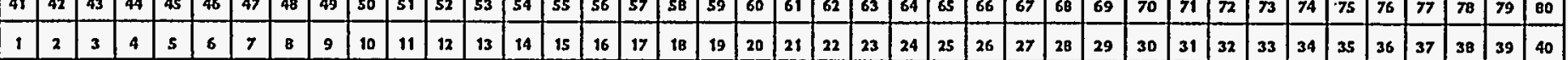


The third data group offers the 29 data variables in their original line-based format. The data values in this data group may vary slightly from those in the gridded data groups since more than one line segment often fell within a single grid cell.

Nine of the 29 data variables within this data base were originally obtained as point data, and constitute the first supplemental data group. These data variables are stored in an exported Arc/Info ${ }^{\mathrm{TM}}$ point coverage and as a flat ASCII file. Each data point is the physical location of the data measure (e.g., latitude-by-longitude location). Data variables within this group include: station name/number, latitude/longitude location, period of record, and the measurements used to derive the relative sea level trend, long-term geologic trend, corrected sea-level trend, local subsidence trend, mean tidal range, maximum tidal range, and mean-tide-level variables.

The second supplemental data group contains a 1:2,000,000 digitized coastline of the U.S. West Coast. The coastlines were extracted from a map originally digitized by the USGS. This base map is intended to be used with the gridded data to provide locational information. These data are stored as an exported Arc/Info ${ }^{\mathrm{TM}}$ line coverage and as a flat ASCII file. The line segments, and their identification numbers, are identical to those used in the first supplemental data group.

\section{Original Data Variables}

The data sets that comprise this data base include the following: elevation, geology, geomorphology, sea level trends, horizontal shoreline displacement (erosion/accretion), tidal ranges, and wave heights. The original data used in developing the data variables included in this NDP were obtained in a variety of scales and formats (e.g., as polygon, line, or point data). Therefore, the methods used to enter the data into the $0.25^{\circ}$ grid cells and $1: 2,000,000$ digitized line segments vary by data set. The variable descriptions used in this report were extracted from annual reports submitted in April 1988, November 1988, April 1991 [Gornitz 1988a, 1988b, 1991; Gornitz and White (Beaty) 1991]; and personal correspondence between Gornitz and Beaty in 1995 and 1996. The following subsections provide a brief description of the data sources and the classification methods used in compiling each data set.

\subsection{Elevation}

The elevation data for this data set were obtained from the NGDC in Boulder, Colorado, as digitized land elevations (to the nearest meter) for $5^{\prime}$ latitude by $5^{\prime}$ longitude grid cells (i.e., ETOPO 5 data) The NGDC grid contained: $<0$ (negative) values for grid cells containing no land within their boundaries; 0 (zero) values for grid cells with land at sea level; and $>0$ (positive) values for grid cells with land above sea level. The NGDC grid cells lying along the West Coast were grouped into the $0.25^{\circ} \times 0.25^{\circ}$ grid cells used in this data base. Minimum, mean, and maximum elevation data are provided for each $0.25^{\circ}$ cell. Each $0.25^{\circ}$ cell may contain as many as nine $5^{\prime}$ grid cells. If only one $5^{\prime}$ grid cell within a given $0.25^{\circ}$ cell contains a positive or zero data value, then the minimum, mean, and maximum elevation variables will be identical. To calculate and transfer these data from $5^{\prime}$ by $5^{\prime}$ to the $0.25^{\circ}$ grid used in this data base, the variables were calculated as follows: 
(1) The number of $5^{\prime}$ NGDC grid cells with positive elevation values within each $0.25^{\circ}$ grid cell was determined.

(2) The minimum elevation was assigned by finding the minimum elevation of all nonnegative $5^{\prime}$ grid cells within each $0.25^{\circ}$ grid cell.

(3) The mean elevation was assigned by averaging the elevations of all non-negative $5^{\prime}$ grid cells within each $0.25^{\circ}$ cell.

(4) The maximum elevation was assigned by finding the maximum elevation of all $5^{\prime}$ grid cells within each $0.25^{\circ}$ grid cell.

To check these data for reasonableness, the $0.25^{\circ}$ grid cells were overlaid onto the $1: 2,000,000$ digitized coastline map of the U.S. West Coast. Through examination of this overlay, it was discovered that peninsulas and small islands often were not represented due to the low resolution of the NGDC grid cells (i.e., mean elevation values were rounded to the nearest whole number). To overcome this limitation, $0.25^{\circ}$ grid cells containing islands and other low-lying landform with negative values in the NGDC data were assumed to lie near mean sea level and were assigned a mean elevation of $0 \mathrm{~m}$. Cells where this correction was necessary are shown in Fig. 3.

Fig. 3. The original NGDC elevation data set and the corrected coastal grid cells with calculated mean elevation values (i.e., values of $0 \mathrm{~m}$ ) used in this NDP.

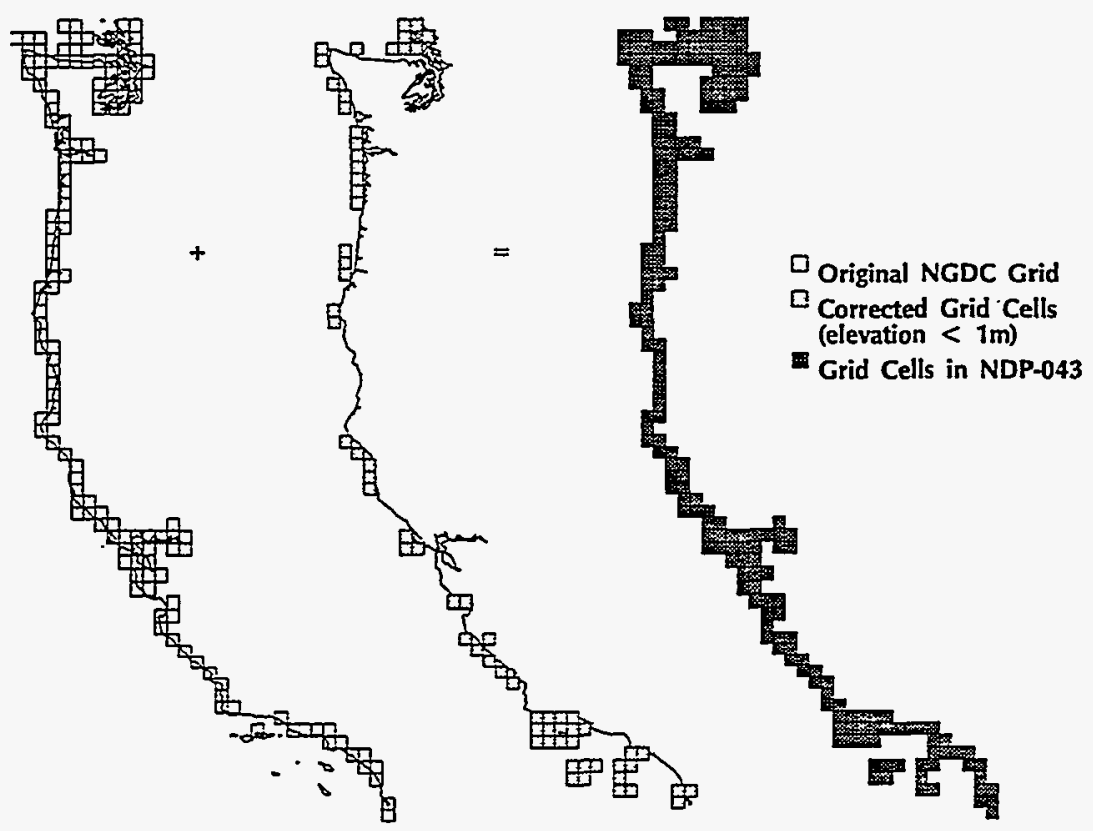


A mean elevation value of $0 \mathrm{~m}$ indicates that the land within the grid cell has a mean elevation of less than $1 \mathrm{~m}$ above sea level. Since 0 is a real data measurement, grid cells with assigned mean elevations are denoted within this data base as having a 0 value for the number of NGDC grid cells variable. A limitation of this method is that even if only a small portion of land is located within the $0.25^{\circ}$ grid cell, the entire grid cell contains a mean elevation value of $0 \mathrm{~m}$.

Mean elevation values range from $0 \mathrm{~m}$ to $885 \mathrm{~m}$ along the West Coast, while the average mean elevation is near $150 \mathrm{~m}$.

\subsection{Geology}

The geology (lithology) variable identifies generalized rock type and is present for all coastal grid cells and line segments within this data base. The geology data were derived from state geologic maps ranging in scale from 1:250,000 to 1:1,000,000 with publication dates from 1968 to 1992 (maps used are listed in section 13.2). The geologic data were classified in terms of an ordinal scale based on the relative hardness of minerals comprising the rock. This geologic classification system was adapted in part from one used by Dolan et al. (1975). It contains 5 major groups further subdivided into 21 subgroups (Table 1).

Table 1. Geologic classification codes assigned to the coastal geology variable.

I. Old Erosion Resistant Rocks (crystalline) 100

A. Igneous, volcanic (basalt, rhyolite, andesite, etc.) 110

B. Igneous, plutonic (granite, granodiorite, etc.) 130

C. Metamorphic (schists, gneisses, quartzite, serpentinite, etc.) 150

$\begin{array}{ll}\text { II. Sedimentary Rocks } & 200\end{array}$

A. Shale 210

B. Siltstone 220

C. Sandstone 230

D. Conglomerate 240

E. Limestone 250

F. Eolianite (calcite-sand) 260

G. Mixed or varied lithology 270 
Table 1. (continued)

Material description

Code

III. Unconsolidated Sediments

A. Mud, Clay $\quad 310$

B. Silt $\quad 320$

C. Sand 330

D. Gravel, conglomerates 340

E. Glacial till $\quad 345$

F. Glacial drift (fluvial-glacial) $\quad 350$

G. Calcareous sediment $\quad 360$

$\begin{array}{ll}\text { H. Mixed or varied lithology } & 370\end{array}$

IV. Recent Volcanic Materials $\quad 400$

A. Lava $\quad 410$

B. Ash, Tempera $\quad 420$

C. Composite $\quad 430$

V. Coral reef $\quad 500$

Appendix B contains a glossary of the terms used in Table 1. This ranking scheme is generalized; consequently, a wide range of erodibilities exist for each rock type listed. The erodibility of each rock depends upon the mineral content, cementation (especially for sedimentary rocks), grain size (for unconsolidated sediments), and presence of planar elements (i.e., bedding, schistosity, cleavage, and fractures) within the rock. The key discriminant between the individual classes identified in Table 1 is the relative resistance of each rock type to physical and chemical weathering.

The geology data were assembled as follows:

(1) Enlarged maps of the 1:2,000,000 digitized U.S. West Coastline included in this NDP were plotted in small sections (i.e., approximately $5^{\circ}$ latitude by $5^{\circ}$ longitude on $3 \mathrm{ft}^{2}$ paper).

(2) Polygons (boxes) were drawn around each coastal segment as identified by state geologic maps (listed in Section 13.3).

(3) The hand-drawn polygons were digitized into $\mathrm{Arc} / \mathrm{Info}^{\mathrm{TM}}$ using the 1:2,000,000 digitized U.S. West Coastline coverage included in this NDP as a backdrop.

(4) These polygons were then overlaid onto the backdrop coverage with the Arc/Info ${ }^{\text {TM }}$ IDENTTTY command whereby the coastal segments took on the values of the polygons. 
(5) For the gridded data groups, a $0.25^{\circ}$ latitude by $0.25^{\circ}$ longitude grid was overlaid onto the 1:2,000,000 digitized line coverage using an additional Arc/Info ${ }^{\text {TM }}$ IDENTTTY command.

Fig. 4. Example of how the geology data were transferred from the 1:2,000,000 digitized coastline map to the $0.25^{\circ}$ by $0.25^{\circ}$ grid cells used in this data base.

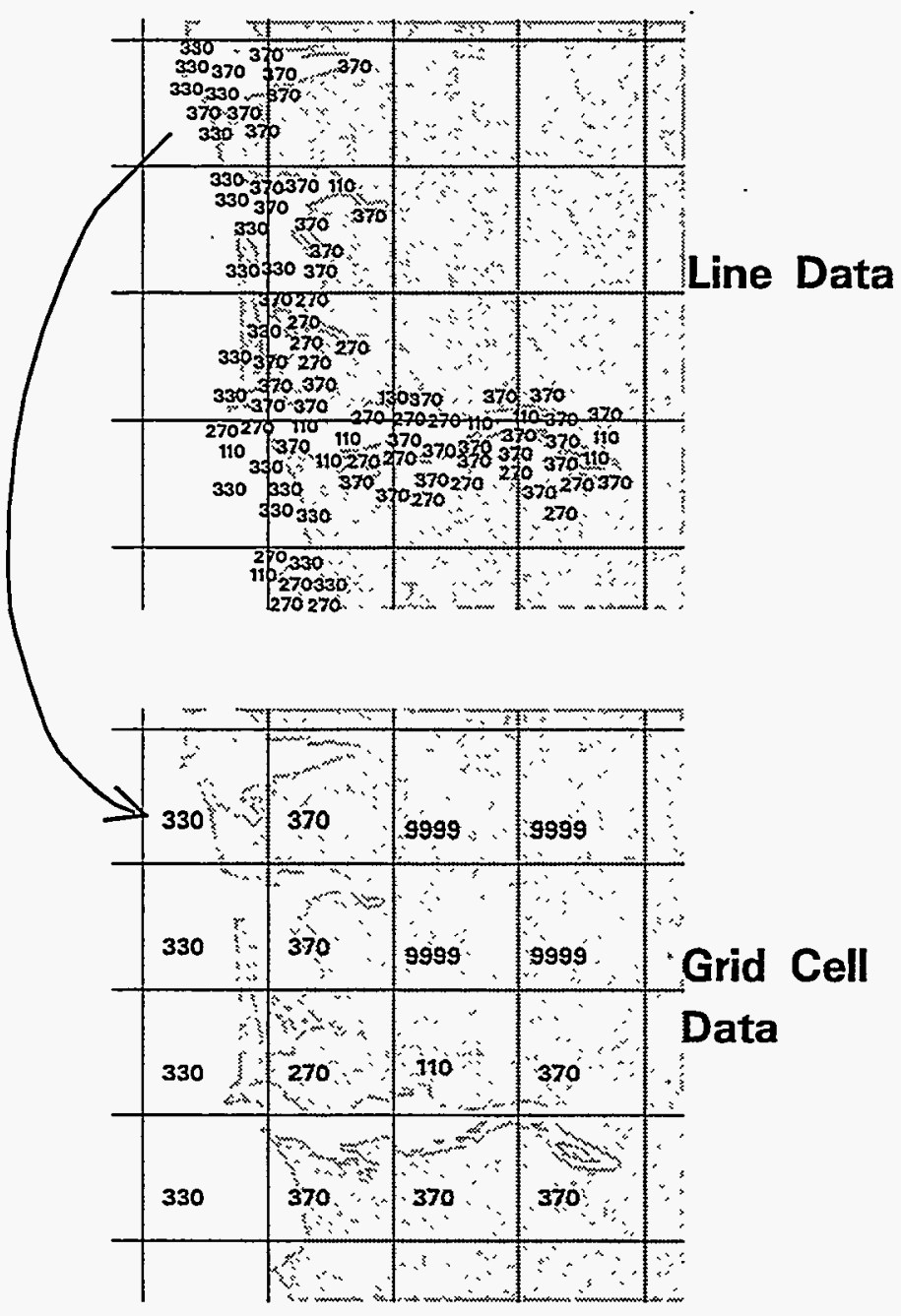


Each grid cell took on the geology code from the line segment with the greatest total length -as illustrated in Fig. 4 (e.g., four line segments in a cell with lengths and geology codes of $100 \mathrm{~km}$, $350 ; 80 \mathrm{~km}, 300 ; 120 \mathrm{~km}, 310$; and $50 \mathrm{~km}, 300$, would yield a cell value of 300 ).

Appendix $\mathrm{C}$ gives a breakdown of the geology codes that occurred within each $0.25^{\circ}$ by $0.25^{\circ}$ coastal grid cell. The geology codes listed in Appendix $\mathrm{C}$ are identical to those found in the line segment-based data groups within this NDP.

In general the bed rock geology of the West Coast consists of five distinct zones. The coastal areas of Washington and Oregon consist of exposed basalts and sedimentary rocks that have been folded and metamorphosed. These rocks were thrust beneath less disturbed Tertiary and sedimentary and volcanic rocks during the Cenozoic uplift. In southern Oregon and northern California four overlapping thrust sheets of volcanic and sedimentary rocks have been intruded by granitic and ultramafic rocks. These sheets are upwarping and in some areas are volcanically active due to the collision of the Pacific and Farallon Plates with North America. This collision is one of the driving forces that has produced the uplift and deformation of the Coast Ranges in northern California. The San Andreas fault, and several others, traverse the Coast Ranges in the north, through the Transverse Ranges in central California, and into the Peninsular Ranges in the south. The Peninsular Ranges are composed of Paleozoic and Mesozoic granitic and metamorphic rocks while the Transverse Ranges are composed of Tertiary sedimentary rocks. The Los Angeles basin is filled with Quaternary sediments (Muhs et al. 1987)

\subsection{Geomorphology}

Geomorphology data are provided for all coastal grid cells in the data base. The data values were interpreted and classified from USGS 1:250,000 topographic maps (maps used are listed in section 13.4). The landforms identified from the 1:250,000 maps may omit landforms with small spatial extent. The classification system used divides the West Coast into two major groups, those formed by erosion and those formed by deposition (Table 2). These two groups are further subdivided into several categories (e.g., marine, nonmarine, glacial, nonglacial, volcanic). Appendix B contains a glossary of the terms used to describe each landform type. Appendix $\mathrm{C}$ gives a breakdown of the geomorphic codes found within each cell (i.e., several line segments may be found within a single cell). Several geomorphic features can occur in more than one environment. Therefore, a fourth digit was added to the three-digit feature identification code. This last digit identifies areas such as marshes, beaches, or areas that have been significantly modified by human activities, which may occur in a number of different geomorphic settings. Thus each geomorphological class is uniquely identified by a four-digit code. 
Table 2. Geomorphology classification codes assigned to the coastal geomorphology variable.

Landform description

Code Beach Man modified

I. Erosional coasts (scoured, beaches poorly developed)

1000

A. Marine with wave erosion and cliffs $\quad 1100$

1. Low $(5-30 \mathrm{~m})$

2. Medium (30-100 m) 1120

3. High $(>100 \mathrm{~m})$

1111

1121

1119

1131

1129

1139

B. Nonmarine (land erosion) 1200

1. Glaciated coast 1210

a. Fjord (drowned valley) 1220

1211

1219

b. Indented fiard (low-lying

1221

1229

inlet)

1231

1239

mud flats

1230

1234

salt marsh

1235

1240

1245 salt marsh

1300

1310

1311

1319

a. Strongly embayed, nonrocky

1320

1321

1329

c. Estuaries

1330

1331

1339

mud flats

1334

salt marsh

1335

mixed types

1338

3. Ice coasts

1400

1500

II. Depositional coasts (sediment

accumulations and well-developed beaches)

2000

A. Marine deposit

2100

2110

2111

2119 salt marsh

2115

2. Beach rock (beach sediment cemented by carbonates) 
Table 2. (concluded)

Landform description

Code

Beach

Man modified

3. Barrier coast

a. barrier island

2121

2129

b. bay barrier

2120

2122

c. mud flats

2123

d. salt marsh

2124

e. cuspate foreland

2125

f. spit

2126

g. mixed

2127

2128

B. River deposits

2200

2210

2220

2224

2. Delta environment

2225

a. mud flats

2228

c. mixed

2211

2219

2229

C. Marine/fluvial deposits (Lagoonal coast)

2250

2221

2229

1. Mud flats

2254

2. Marsh/mangrove

2255

3. Mixed

2258

D. Glacial deposits

1. Outwash plain

2310

2320

2330

3. Drumlin

2315

salt marsh

.2340

2345

salt marsh

2350

2251

2259

5. Composite

2400

1. Reefs (coral, oysters, algal)

a. fringing

2410

2411

2419

b. barrier

2420

2421

2429

2. Barrier reef with an associated mangrove swamp

2425

3. Swamp/mangrove

2450

2451

2459

F. Volcanic coasts

2500

1. Lava flows

2510

2511

2300

2311

2319

2329

2339

2. Tephra, ash

2520

2521

2519

2530

2531

2529

2539 
Based on Table 2, all grid cells on the West Coast have been assigned a data value, which is the code with the maximum shore length within each cell. The geomorphology data were compiled using the same procedures described for the geology data. Appendix $\mathrm{C}$ gives a breakdown of the geomorphology codes that occurred within each grid cell.

\subsection{Sea-Level Trends}

The sea level trend data set for the U.S. West Coast was derived from calculated relative sea-level trend measurements in mm/year for 16 tide-gauge stations (Woodworth 1995; Spencer and Woodworth 1993). This relative sea-level trend was calculated by a linear least-squares regression fitted to the time series of mean annual sea-level elevations for each of the 16 tide-gauge stations. Table 3 illustrates this information and Fig. 5. shows the locations of the stations listed in Table 3.

Table 3. Relative sea-level trends, U.S. West Coast, $\mathrm{mm} / \mathrm{yr}$.

\begin{tabular}{lllcr}
\hline Station & Latitude & Longitude & $\begin{array}{c}\text { Length of } \\
\text { Record (yr) }\end{array}$ & $\begin{array}{c}\text { Sea-Level } \\
\text { Trend (mm/yr) }\end{array}$ \\
\hline & & & & \\
Friday Harbor & $48^{\circ} 33^{\prime} \mathrm{N}$ & $123^{\circ} 00^{\prime} \mathrm{W}$ & 58 & 1.12 \\
Neah Bay & $48^{\circ} 22 \mathrm{~N}$ & $124^{\circ} 37^{\prime} \mathrm{W}$ & 56 & -1.61 \\
Port Townsend & $48^{\circ} 07^{\prime} \mathrm{N}$ & $122^{\circ} 45^{\prime} \mathrm{W}$ & 21 & 1.98 \\
Seattle & $47^{\circ} 36^{\prime} \mathrm{N}$ & $122^{\circ} 20^{\prime} \mathrm{W}$ & 96 & 2.01 \\
Astoria & $46^{\circ} 13^{\prime} \mathrm{N}$ & $123^{\circ} 46^{\prime} \mathrm{W}$ & 68 & -0.60 \\
South Beach & $44^{\circ} 38^{\prime} \mathrm{N}$ & $124^{\circ} 03^{\prime} \mathrm{W}$ & 22 & 4.39 \\
Crescent City & $41^{\circ} 45^{\top} \mathrm{N}$ & $124^{\circ} 12^{\prime} \mathrm{W}$ & 60 & -0.72 \\
San Francisco & $37^{\circ} 48^{\prime} \mathrm{N}$ & $122^{\circ} 28^{\prime} \mathrm{W}$ & 140 & 1.37 \\
Alameda & $37^{\circ} 46^{\prime} \mathrm{N}$ & $122^{\circ} 18^{\prime} \mathrm{W}$ & 54 & 0.77 \\
Monterey & $36^{\circ} 36^{\top} \mathrm{N}$ & $121^{\circ} 53^{\prime} \mathrm{W}$ & 21 & 3.11 \\
Port San Luis & $35^{\circ} 10^{\top} \mathrm{N}$ & $120^{\circ} 45^{\prime} \mathrm{W}$ & 45 & 1.24 \\
Santa Monica & $34^{\circ} 01^{\prime} \mathrm{N}$ & $118^{\circ} 30^{\prime} \mathrm{W}$ & 53 & 1.98 \\
Los Angeles & $33^{\circ} 43^{\prime} \mathrm{N}$ & $118^{\circ} 16^{\prime} \mathrm{W}$ & 70 & 0.85 \\
Newport Beach & $33^{\circ} 36^{\prime} \mathrm{N}$ & $117^{\circ} 53^{\prime} \mathrm{W}$ & 35 & 1.65 \\
La Jolla & $32^{\circ} 52^{\prime} \mathrm{N}$ & $117^{\circ} 15^{\prime} \mathrm{W}$ & 65 & 2.42 \\
San Diego & $32^{\circ} 43^{\prime} \mathrm{N}$ & $117^{\circ} 10^{\prime} \mathrm{W}$ & 87 & 2.24
\end{tabular}

Data from Permanent Service for Mean Sea Level, Sept. 1996. 
Fig. 5. Locations of the 16 sea-level gauge stations used in this NDP.

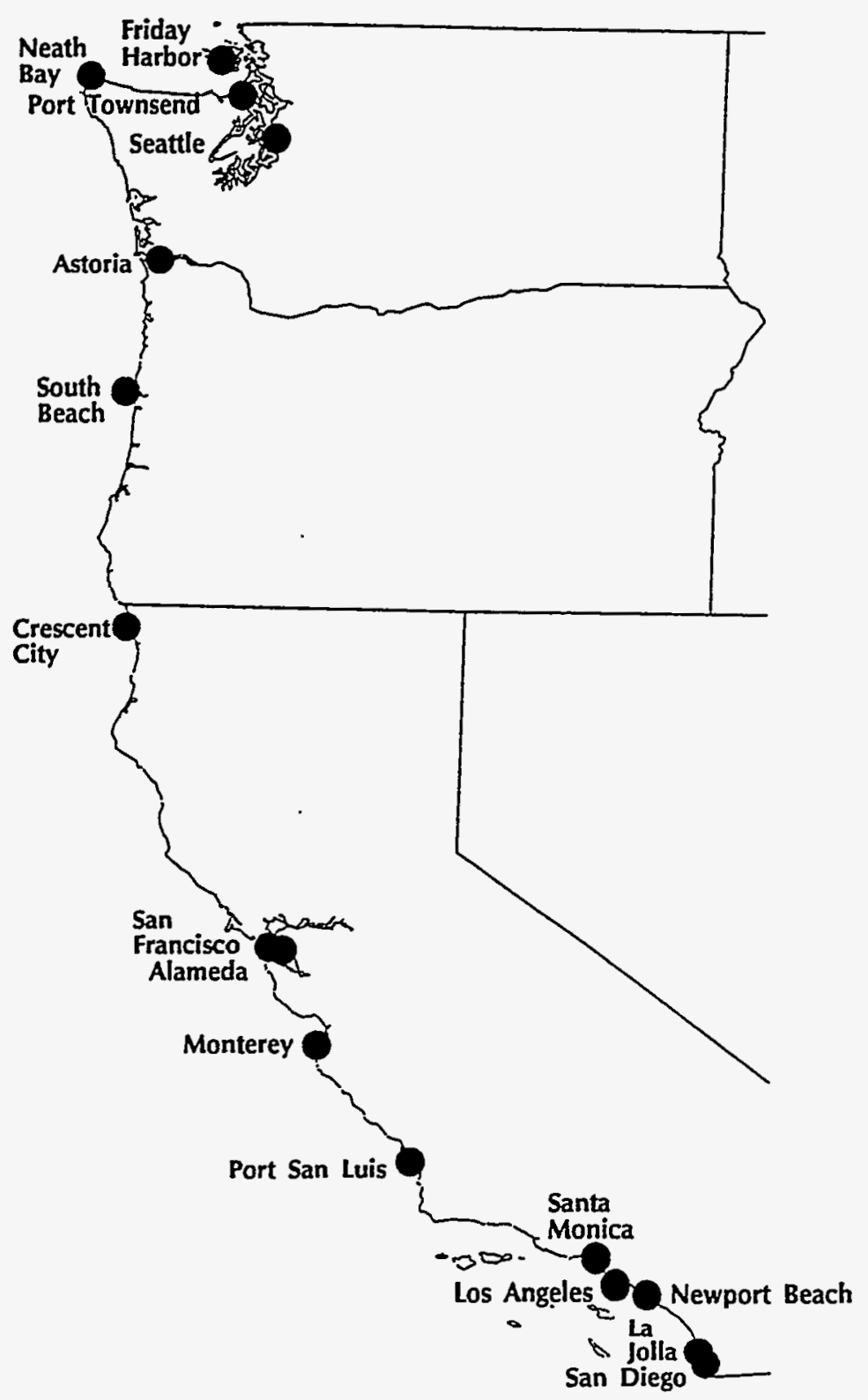

To obtain a relative sea-level trend variable for the $0.25^{\circ}$ grid cells along the West Coast lying between tide-gauge stations, the following interpolation procedure was adopted:

(1) The tide-gauge stations and the sea-level trends were plotted along a 1:2,000,000 digitized U.S. West coastline (Fig. 5).

(2) The $0.25^{\circ}$ by $0.25^{\circ}$ grid used in this NDP was then overlaid onto the tide-gauge stations with an Arc/Info ${ }^{\mathrm{TM}}$ IDENTITY command, whereby the grid cells took on the values of the tide-gauge stations. 
(3) For each coastal grid cell without data, the difference in relative sea levels was calculated between the two nearest gauge stations (i.e., occurring east and west or north and south of the given grid cell).

(4) The difference between the relative sea levels was then divided by the number of grid rows, plus one, occurring between the grid cells containing gauge stations. This value was called the slope factor.

(5) The slope factor was then multiplied by the number of grid rows from the grid cell being calculated to the nearest station (i.e., western-most or southern-most station) and added to the station's relative sea-level trend.

(6) The resultant of these five steps is the relative sea-level trend variable within the gridded data groups in this data set.

It should be noted that tide gauges measure sea-level variations in relation to a fixed benchmark on land and are therefore relative, due to vertical land movements and real changes in ocean levels. Information on long-term vertical movements along the U.S. West Coast is summarized in Appendix D. Because of active tectonism along the West Coast, which varies from place to place and can affect the relative sea-level curves, the above interpolation procedure should be used with caution. See comments in Sect. 10 and Appendix D.

The procedure for calculating the uplift or local subsidence trend variable along the U.S. West Coast differs from that used for the U.S. East and Gulf Coasts (Gornitz and Lebedeff 1987). Along the U.S. East Coast, Holocene paleosealevel indicators were used to calculate a long-term geologic trend variable (Gornitz and Seeber 1990). This geologic trend variable was then subtracted from the present relative sea-level trend (as measured by tide gauges) to provide a corrected sea-level trend variable for each $0.25^{\circ}$ coastal grid cell. The average value of these corrected trends was used to obtain the regional eustatic trend (i.e., $1.25 \mathrm{~mm} / \mathrm{yr}$ ). This eustatic trend was then subtracted from the relative sea-level trend variable to yield a local subsidence trend variable for each $0.25^{\circ}$ East Coast grid cell.

Along the U.S. Gulf Coast, Holocene paleosealevel indicators were not available, so the geologic trend variable for each $0.25^{\circ}$ Gulf coastal grid cell was set to 0.0 for compatibility purposes between the two NDPs (i.e., NDP-043A and NDP-043B). The local subsidence factor for the Gulf Coast was calculated by assuming the global eustatic rate of sea-level rise to be $1.5 \mathrm{~mm}$ per year, as reported by the Intergovernmental Panel on Climate Change (IPCC) (Houghton et al. 1990), and subtracting this rate (i.e., $1.5 \mathrm{~mm} / \mathrm{yr}$ ) from the relative sea-level trend variable. The resultant difference along the U.S. Gulf Coast was the uplift or subsidence trend variable for each $0.25^{\circ}$ coastal grid cell.

Along the U.S. West Coast, Holocene paleosealevel indicators are found only in a small number of coastal marshes and bays, where they record at least a half dozen discrete seismic events (Atwater 1987; Atwater et al. 1991; and Darienzo et al. 1994) and do not yield a continuous sea-level curve. Late Quaternary (i.e., $\leq 125,000$ years) raised marine terraces, which occur along much of the West Coast, integrate the permanent deformation produced over multiple earthquake cycles. Thus, raised terrace data can be used to derive long-term geologic trends for selected data points (Appendix D, Table 1).

Because of insufficient data, there are no real data values assigned to the long-term geologic trend variable in this data set. A value of 0.0 was assigned to West coastal grid cells with a data value for the calculated relative sea-level trend variable; while a value of -9999.99 was assigned to grid cells 
with no data value for the calculated relative sea-level trend variable. While both values, 0.0 and -9999.99 , indicate no data for the long-term geologic trend variable, a value of 0.0 serves two purposes. First, it indicates those grid cells in which the data provided in Table 1 of Appendix D may be used to calculate a long-term geologic trend variable. Secondly, it allows for compatibility among the data sets in this series of NDPs (NDP-043A, NDP-043B, and this document, NDP-043C). Consequently, the corrected sea-level trend variable within this data set contains a value that appears to be identical to the calculated relative sea-level trend variable; however, nothing has truly been corrected here [i.e., corrected sea-level trend $=$ calculated relative sea-level trend - long-term geologic trend $(0.0)]$.

The uplift or subsidence trend variable for the U.S. West Coast was calculated by assuming a global eustatic rate of sea-level rise of $1.5 \mathrm{~mm} / \mathrm{yr}$, as reported by the IPCC (Houghton et al. 1996), and subtracting this rate (i.e., $1.5 \mathrm{~mm} / \mathrm{yr}$ ) from the calculated relative sea-level trend variable. The resultant difference is the local subsidence or uplift trend variable for each $0.25^{\circ}$ coastal grid cell along the West Coast.

The local uplift or subsidence variable gives an indication of the relative vulnerability of each coastal grid cell and line segment to sea-level rise. This variable may be used to identify areas that are uplifting or subsiding faster or slower than the regional averages. It is also added to any future projected global sea-level curves, to adjust the global curve to local conditions.

The ARC/INFO ${ }^{\mathrm{TM}}$ IDENTITY command was used to overlay the coastal $0.25^{\circ}$ by $0.25^{\circ}$ grid cells onto the 1:2,000,000 digitized West coastline. The resulting relative sea-level trend, geologic trend, corrected relative sea-level trend, and local uplift or subsidence trend variables are found in the linebased data groups herein.

\subsection{Horizontal Shoreline Displacement (Erosion/Accretion)}

The erosion/accretion data used in the development of the horizontal shoreline displacement data set were extracted and modified from the Coastal Erosion Information System (CEIS) developed by May et al. $(1982,1983)$ and Dolan et al. $(1975,1983,1989)$. The CEIS data are limited in extent to coastlines that open into the ocean or large bays. The displacement data within the CEIS data base were originally obtained from over 500 individuals or organizations with records ranging in length from 20 to 165 years. The majority of the shoreline displacement measurements, however, were made from historic maps and aerial photographs that cover the U.S. West Coast for a minimum of 40 to 50 years. Most of the information was originally obtained from published reports or from regionally available high-resolution data sets (e.g., Dolan et al. 1980). Of the data within CEIS, 25\% were obtained in raw form and converted into point measurements of erosion or accretion. In conducting the measurement and data compilation steps of the raw data, May et al. (1982) used the landward limit of wetted sand as the criteria for identifying the shoreline. This definition was selected because it produced the most consistent results in the photo-interpretation process.

By comparing present and past shorelines from maps, aerial photographs, and data from regional studies, May et al. (1982) were able to obtain rates of change, expressed in $\mathrm{m} /$ year, for coastal points on the West Coast. May et al. (1982) then averaged and extrapolated the point data into $3^{\prime}$ latitude by $3^{\prime}$ longitude grid cells (in locations with sparse data $7.5^{\prime}$ and $15^{\prime}$ grid cells were used) to minimize the problems associated with mapping errors, imprecise shoreline definitions, and poor temporal resolution within the original erosion/accretion data sources. These $3^{\prime}, 7.5^{\prime}$, or $15^{\prime}$ grid cells were then overlaid onto the $0.25^{\circ}$ grid cells used in this data base to derive the following data variables (values in 
$\mathrm{m}$ /year): minimum erosion trend, mean erosion trend, maximum erosion trend, and the number of $3^{\prime}$, $7.5^{\prime}$, or $15^{\prime}$ cells used in deriving the data for each $0.25^{\circ}$ grid cell.

To transfer this information to the $0.25^{\circ}$ grid cells used in this data set, the erosion variables were recalculated as follows:

(1) The number of $3^{\prime}, 7.5^{\prime}$, or $15^{\prime}$ grid cells that occur in a given $0.25^{\circ}$ grid cell was determined. These $3^{\prime}, 7.5^{\prime}$, or $15^{\prime}$ cells were used to calculate the minimum, mean, or maximum erosion rate variables.

(2) The minimum erosion rate for a $0.25^{\circ}$ grid cell is the minimum erosion rate found in the $3^{\prime}, 7.5^{\prime}$, or $15^{\prime}$ grid cells within a $0.25^{\circ}$ grid cell.

(3) The mean erosion rate for a $0.25^{\circ}$ grid cell is the weighted average of the erosion rates of all $3^{\prime}$, $7.5^{\prime}$, or $15^{\prime}$ grid cells within a $0.25^{\circ}$ grid cell.

(4) The maximum erosion rate for a $0.25^{\circ}$ grid cell is the maximum erosion rate found in the $3^{\prime}, 7.5^{\prime}$, or $15^{\prime}$ grid cells within a $0.25^{\circ}$ grid cell.

Fig. 6 gives an example of how the overlay process was used to determine the number of data values from $3^{\prime}, 7.5^{\prime}$, or $15^{\prime}$ grid cells used in calculating the values contained in the $0.25^{\circ}$ grid cells distributed with this NDP.

Fig. 6. Example of how the shoreline displacement data were transferred to the $0.25^{\circ}$ grid cells used in this NDP. The variable ERNUM is the number of $3^{\prime}, 7.5^{\prime}$, or $15^{\prime}$ grid cells used in calculating the erosion variables in a $0.25^{\circ}$ grid cell.

Data Source Grid

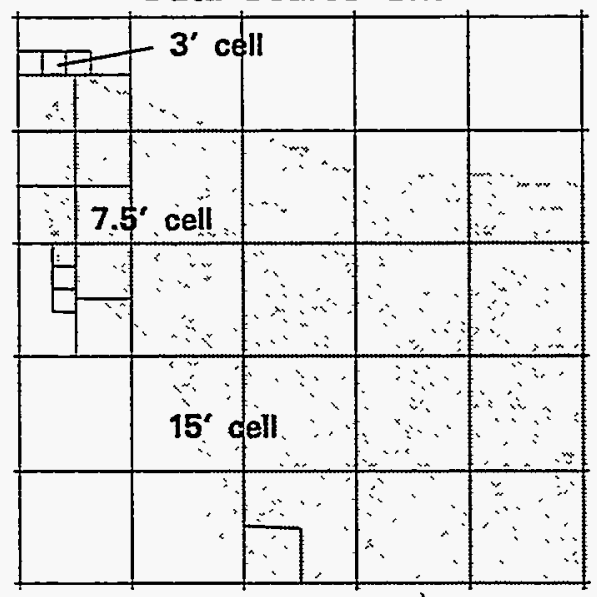

Data Grid in this NDP

\begin{tabular}{|c|c|c|c|c|}
\hline ENNUM =5 & ERNUM=1 & ERNUM $=1$ & no data & no dato \\
\hline 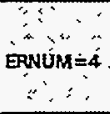 & : Ódats & 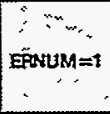 & ERNUM $=\hat{1}$ & ERNUM=1 \\
\hline ERNUMM $=6$ & 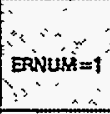 & na dăta & no dato & 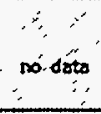 \\
\hline no data & $\begin{array}{c}Y^{\prime} \\
\text { ERNUM }=1 \\
\vdots \\
\end{array}$ & : no data & noidate. & ino dater \\
\hline no dato & ERNUM=7 & $\begin{array}{c}\therefore \\
\because \\
\therefore\end{array}$ & $\therefore$ & 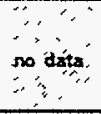 \\
\hline
\end{tabular}


The gridded data were then overlaid onto a 1:2,000;000 digitized U.S. West Coastline to form the line segment version of these data. Based on the length of record (from 20 to 165 years, depending on location), and the errors inherent in the data, the reported shoreline displacement trends are average values that are highly variable over time; as such, rates of change less than $\pm 0.6 \mathrm{~m} / \mathrm{year}$ are not considered significant.

\subsection{Tidal Ranges}

The tidal range data set was obtained from tide tables published by NOAA's National Ocean Service (NOS) for 410 stations located on the West Coast (NOS 1992). These station data were entered into the Arc/Info ${ }^{\mathrm{TM}}$ GIS as point data and are available in the supplemental data group. The supplemental data group contains the name, identification number, longitude/latitude, mean tidal range, maximum tidal range, and mean tide level for each tide-range station. The data for each station were overlaid onto the $0.25^{\circ}$ grid cells used in this data set, and the variables calculated based on the stations that fell within each grid cell (values expressed in meters) as follows:

(1) The number of tide stations that fell within each $0.25^{\circ}$ grid cell was calculated. The stations within each cell were then used to derive the mean tide level and the mean and maximum tidal ranges for each $0.25^{\circ}$ grid cell.

(2) The mean tidal range for each grid cell is the average of the diurnal tidal ranges of all stations within a given cell.

(3) The maximum tide range for each grid cell is the largest value found within the diurnal tide ranges of all stations within a given cell.

(4) The mean tide level for each grid cell is the average of the mean tide levels of all stations within a given cell.

The gridded data obtained from this process were then overlaid onto the U.S. West Coastline coverage using the Arc/Info ${ }^{\mathrm{TM}}$ IDENTITY command to transfer the calculated data into the line segment version of these data.

The mean tidal range at a given tide station in this data set is defined as the difference in height between mean high water and mean low water in 1992 . Tide heights vary annually, but their differences are relatively constant in relation to one another. The maximum tide range variable contains the "diurnal tide range." The diurnal tide range is defined as the difference in height between mean higher high water and mean lower low water (NOS 1992). The mean tide level variable is defined as a plane midway between mean low water and mean high water in 1992. This value is reckoned from chart datums. The chart datums used in the tide tables for the mean tide level variable are from the West Coast Low Water Datum.

The magnitude of the tidal range variables defined above has been linked to both inundation and erosion hazards. Although a large tidal range dissipates wave energy, it also delineates a broad zone of low-lying intertidal wetlands susceptible to inundation. Furthermore, the velocity of tidal currents in estuaries depends on the tide range, as well as the asymmetry of the tidal cycle and channel morphology. Therefore, when holding these other factors constant, high-tide ranges are associated with stronger tidal currents capable of eroding and transporting sediment offshore. 


\subsection{Wave Heights}

This wave-height data set contains three data variables (all variables expressed in meters): the maximum significant wave height, the 20-year mean wave height, and the standard deviation of the mean). This data set was originally obtained from published documents of the Coastal Engineering Research Center (CERC), U.S. Army Corps of Engineers, Wave Information Study (WIS). In the study CERC calculated wind speeds from station histories, National Weather Service surface charts, surface pressure data, ships-at-sea observations, and monthly air-sea temperature gradients, in a 3-phase process. Phase 1 hindcasted wind speeds/directions for each 120 nautical-mile-long segment while Phase 2 hindcasted wind speeds and deep ocean waves for a 30 nautical-mile spacing (Hubertz et al. 1992). In Phase 3, wind data were input into a transformation model that hindcasted near-shore wave heights for 10 nautical-mile-segments of the West Coast (Jensen 1989; Corson et al. 1987).

The 10 nautical-mile-segment data were originally received as point data which included longitude and latitude coordinates, maximum significant wave height, 20-year mean wave height, and the standard deviation of the mean wave height. To transfer this point data into the $0.25^{\circ}$ longitude by $0.25^{\circ}$ grid cells used in this NDP the following methodology was used:

(1) The longitude/latitude coordinates were read into $A R C / \mathbb{N F O}{ }^{T M}$ to produce a point coverage. This point coverage was then plotted over the 1:2,000,000 digitized U.S. West coastline and checked for reasonableness.

(2) $1.0^{\circ}$ was added to and subtracted from the original longitude coordinates to produce a line segment coverage which defined each 10 nautical-mile line segment along the West Coast.

3) The Arc/Info ${ }^{\text {TM }}$ BUFFER command was used on the 1:2,000,000 digitized line segment coverage, to form a polygon of the study area.

(4) The polygon coverage produçed in step 3 was read into ARCEDIT, where it was joined with the line segment coverage produced in step 2. All errors and discrepancies were corrected, and a final polygon coverage defining each 10 nautical-mile segment along the U.S. West Coast was produced.

(5) The Arc/Info ${ }^{\mathrm{TM}}$ IDENTITY command was then used to transfer the polygon data produced in number 4 above onto the 1:2,000,000 digitized line segments used in this NDP.

(6) Finally, the Arc/Info ${ }^{\mathrm{TM}}$ IDENTITY command was used once more to transfer the 10 nautical-mile line segment data into the $0.25^{\circ}$ longitude by $0.25^{\circ}$ grid cells used in this NDP.

The WIS data variables (i.e., maximum significant wave height, 20-year mean wave height, and the standard deviation of the mean) were transferred during this overlay process and are included within this NDP. Figure 7 illustrates this transformation process. 


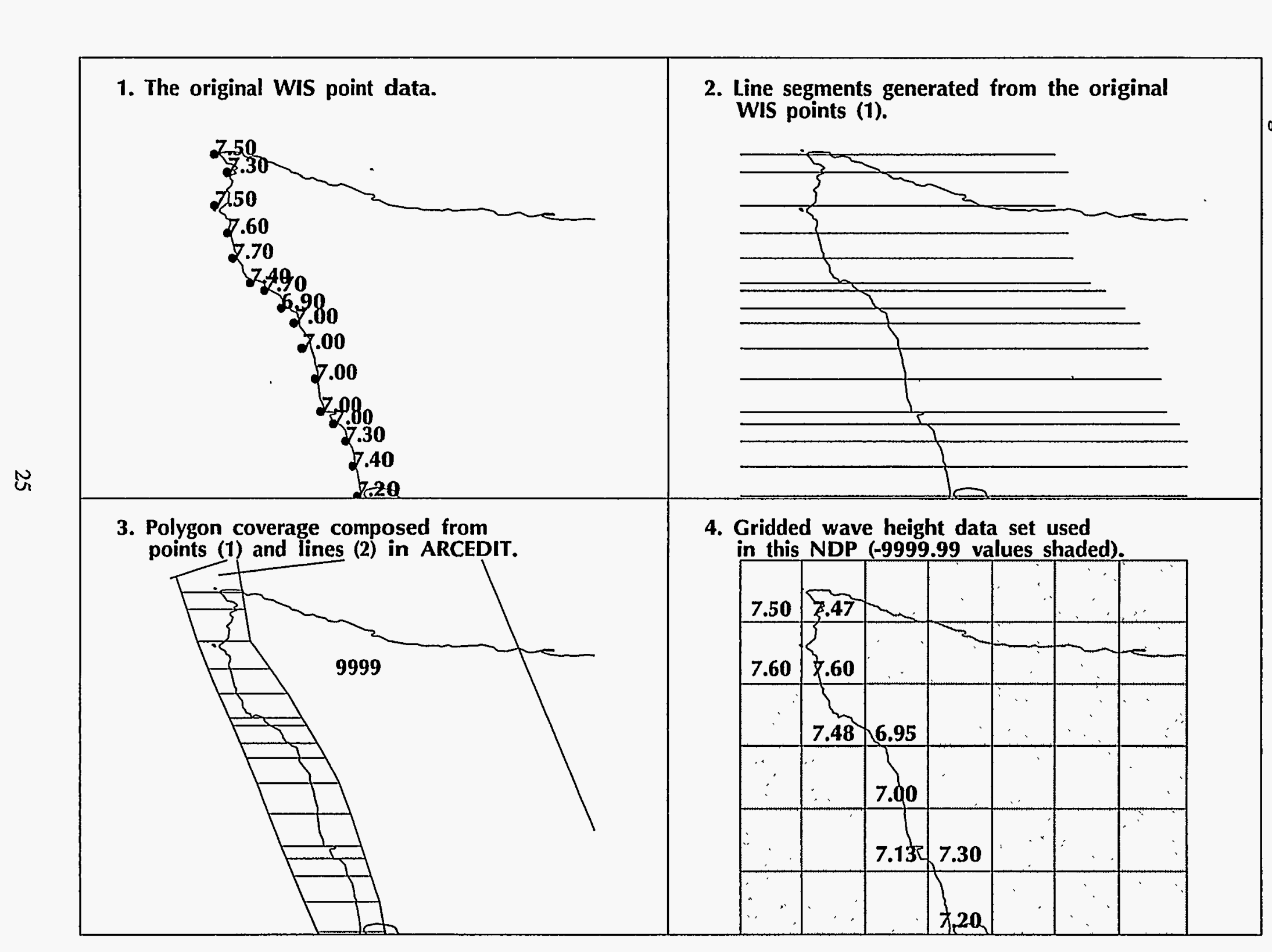

高

哭 


\section{Relative Risk Factors}

The previous section discussed how the original 22 data variables within this data base were obtained and entered into the GIS. These data were directly digitized from maps or copied from computer tapes and imported into the Arc/Info ${ }^{\mathrm{TM}}$ GIS, where the information was analyzed and the data values were incorporated into the $0.25^{\circ}$ grid cells and 1:2,000,000 digitized line segments. The entry of these data into common formats (i.e., $0.25^{\circ}$ grid cells and 1:2,000,000 digitized line segments) has made it possible to relate and manipulate the data to identify relationships among the different variables.

A vulnerable coastline is characterized by low coastal relief, subsidence, extensive shore line retreat, and high wave/tide energies (Gornitz et al. 1991). To simplify the manipulation process, seven of the original data variables were classified into seven new "risk" variables. Each risk variable ranges in value from 1 to 5 and indicates the cell's relative risk to erosion or inundation. The risk assignments for mean elevation, mean shoreline displacement, local subsidence trend, mean tidal range, and maximum significant wave height (i.e., the numeric data variables) are given in Table 3 . The risk assignments for geology and geomorphology (i.e., the nominal data) are given in Tables 4 and 5, respectively. These risk assignments are discussed in greater detail in Gornitz et al. (1991), Gornitz and White (1991) and Gornitz et al. (1994) -reprinted in Appendix D.

Table 4. Assignment of relative risk factors for elevation, shoreline displacement, local subsidence trend, tidal range, and wave height.

\begin{tabular}{|c|c|c|c|c|c|}
\hline Variable: & $\begin{array}{c}\text { Very low } \\
1\end{array}$ & $\begin{array}{c}\text { Low } \\
2\end{array}$ & $\begin{array}{c}\text { Moderate } \\
3\end{array}$ & $\begin{array}{l}\text { High } \\
4\end{array}$ & $\begin{array}{l}\text { Very high } \\
5\end{array}$ \\
\hline Mean elevation (m) & $>30$ & $\begin{array}{r}>20 \\
\text { and } \\
\leq 30\end{array}$ & $\begin{array}{r}>10 \\
\text { and } \\
\leq 20\end{array}$ & $\begin{array}{r}>5 \\
\text { and } \\
\leq 10\end{array}$ & $\begin{array}{l}\geq 0 \\
\text { and } \\
\leq 5\end{array}$ \\
\hline $\begin{array}{l}\text { Mean shoreline } \\
\text { displacement } \\
\text { (m/year) }\end{array}$ & $\begin{array}{r}>2.0 \\
\text { Accretion }\end{array}$ & $\begin{array}{l}>1 \\
\text { and } \\
\leq 2\end{array}$ & $\begin{array}{l}>-1 \\
\text { and } \\
\leq+1\end{array}$ & $\begin{array}{l}>-2 \\
\text { and } \\
\leq-1\end{array}$ & $\begin{array}{r}\leq-2 \\
\text { Erosion }\end{array}$ \\
\hline $\begin{array}{l}\text { Local subsidence } \\
\text { trend (mm/year) }\end{array}$ & $\begin{array}{r}<-1 \\
\text { Land } \\
\text { rising }\end{array}$ & $\begin{array}{l}\geq-1 \\
\text { and } \\
\leq 1\end{array}$ & $\begin{array}{l}>1 \\
\text { and } \\
\leq 2\end{array}$ & $\begin{array}{l}>2 \\
\text { and } \\
\leq 4\end{array}$ & $\begin{array}{r}>4.0 \\
\text { Land } \\
\text { sinking }\end{array}$ \\
\hline Mean tidal range $(\mathrm{m})$ & $\begin{array}{r}<1.0 \\
\text { Microtidal }\end{array}$ & $\begin{array}{l}\geq 1 \\
\text { and } \\
<2\end{array}$ & $\begin{array}{l}\geq 2 \\
\text { and } \\
\leq 4\end{array}$ & $\begin{array}{l}>4 \\
\text { and } \\
\leq 6\end{array}$ & $\begin{array}{r}>6.0 \\
\text { Macrotidal }\end{array}$ \\
\hline $\begin{array}{l}\text { Maximum significant } \\
\text { wave height (m) }\end{array}$ & $\begin{array}{l}\geq 0 \\
\text { and } \\
<3\end{array}$ & $\begin{array}{l}\geq 3 \\
\text { and } \\
<5\end{array}$ & $\begin{array}{l}\geq 5 \\
\text { and } \\
<6\end{array}$ & $\begin{array}{r}\geq 6 \\
\text { and } \\
<6.9\end{array}$ & $\geq 6.9$ \\
\hline
\end{tabular}


Table 5. Assignment of relative risk factors for geology.

\begin{tabular}{ll}
\hline Rank & \multicolumn{1}{c}{ Geology values $^{2}$} \\
\hline 1 & $100,110,130,410$ \\
2 & 150 \\
3 & $\begin{array}{l}200,210,220,230,240,250,260,270,400, \\
430,500\end{array}$ \\
4 & $300,340,345,370$ \\
5 & $310,320,330,350,360,420$ \\
\hline
\end{tabular}

${ }^{2}$ See Table 1 for description of geology values.

Table 6. Assignment of relative risk factors for geomorphology.

\begin{tabular}{|c|c|}
\hline Rank & Geomorphology values ${ }^{b}$ \\
\hline 1 & $\begin{array}{l}1130,1139,1210,1219,1220,1229,1230,1239,1240 \text {, } \\
1249,1320,1329,2510,2519\end{array}$ \\
\hline 2 & $\begin{array}{l}1120,1129,1131,1211,1221,1231,1234,1235 \\
1241,1245,1310,1319,2511\end{array}$ \\
\hline 3 & $\begin{array}{l}1110,1119,1121,1311,1321,1335,1338,2112, \\
2115,2125,2225,2255,2300,2315,2320,2329, \\
2330,2339,2340,2345,2349,2350,2359,2400,2410, \\
2419,2420,2425,2429,2450,2459,2500,2530,2539\end{array}$ \\
\hline 4 & $\begin{array}{l}1111,1330,1339,2200,2210,2219,2228,2250 \\
2258,2259,2310,2319,2321,2331,2341,2351 \\
2411,2421,2451,2520,2529\end{array}$ \\
\hline 5 & $\begin{array}{l}1331,1334,2110,2111,2119,2120,2121,2122 \\
2123,2124,2126,2127,2128,2129,2211,2220 \\
2221,2224,2229,2251,2254,2311,2521,2531\end{array}$ \\
\hline
\end{tabular}

${ }^{b}$ See Table 2 for a description of geomorphology values. 


\section{The Coastal Vulnerability Index}

The seven relative risk variables contained within this data base may be used to formulate a coastal vulnerability index. This index may be used to identify areas that are at risk to erosion and/or permanent or temporary inundation. Grid cells and/or line segments with high index values will tend to have low reliefs, erodible substrates, histories of subsidence and shoreline retreat, and high wave and tide energies (Gornitz et al. 1991). However, when several risk factors for a given area are missing data, then any calculated index will underestimate the risk of the area in question.

The following methods for deriving such an index have been tested on a sample of 93 randomly selected coastal segments and seem to be adequate for the task when the number of risk factors that are missing data, for a given location, are less than three. The addition of new variables to this data base or the use of a different classification system for the risk variables may result in index values that differ significantly from those that would be produced using the formulas shown. These formulas were proposed and tested for the derivation of a Coastal Vulnerability Index (CVI) in Gornitz et al. (1991); CVI 5 was used in Gornitz and White (1991), Gornitz et al. (1991), and Gornitz (1990, 1991).

Product mean:

Modified product mean:

Average sum of squares:

Modified product mean (2):

Square root of product mean:

Sum of products:

Where: $\mathrm{n}=$ variables present $\mathrm{x}_{2}=$ local subsidence trend $\mathrm{x}_{4}=$ geomorphology $\mathrm{x}_{6}=$ maximum wave height

$$
\mathrm{CVI}_{1}=\frac{\left(\mathrm{x}_{1} * \mathrm{x}_{2} * \mathrm{x}_{3} * \mathrm{x}_{1} * \ldots \mathrm{x}_{\mathrm{n}}\right)}{\mathrm{n}}
$$

$$
\mathrm{CVI}_{2}=\left[\mathrm{x}_{1} * \mathrm{x}_{2} * 1 / 2\left(\mathrm{x}_{3}+\mathrm{x}_{4}\right) * \mathrm{x}_{5} * 1 / 2\left(\mathrm{x}_{6}+\mathrm{x}_{7}\right)\right]
$$$$
\mathrm{CVI}_{3}=\frac{\left(\mathrm{x}_{1}{ }^{2}+\mathrm{x}_{2}{ }^{2}+\mathrm{x}_{3}{ }^{2}+\mathrm{x}_{4}{ }^{2}+\ldots \mathrm{x}_{n}{ }^{2}\right)}{\mathrm{n}},
$$$$
\mathrm{CVI}_{4}=\frac{\left(\mathrm{x}_{1} * \mathrm{x}_{2} * \mathrm{x}_{3} * \mathrm{x}_{4} * \ldots \mathrm{x}_{\mathrm{n}}\right)}{5^{(\mathrm{n}-4)}}
$$

$$
\mathrm{CVI}_{5}=\left[\mathrm{CVI}_{1}\right]^{1 / 2}, \quad \text { and }
$$

$$
\mathrm{CVI}_{6}=4 \mathrm{x}_{1}+4 \mathrm{x}_{2}+2\left(\mathrm{x}_{3}+\mathrm{x}_{4}\right)+4 \mathrm{x}_{5}+2\left(\mathrm{x}_{6}+\mathrm{x}_{7}\right) \text {. }
$$

$\mathrm{x}_{1}=$ mean elevation

$\mathrm{x}_{3}=$ geology

$\mathrm{x}_{5}=$ mean shoreline displacement

$x_{7}=$ mean tidal range.

The relative risk variables were assigned to one of five risk classes on the basis of Tables 3,4 , and 5. Errors in the classification of any of the variables could result in a misclassification of up to one risk class for each risk variable. The sensitivity of each of the six CVI formulas to misclassification errors was tested by changing the relative risk factor of 1 to 3 risk variables from high to low (i.e., 5 to 1) while holding the others fixed at a value of 5 (Table 6). The calculated sensitivity is the percentage change from the original CVI, with all variables set to five, such that the greater the value the greater the percent change. It was found that for some CVIs, a change in two or more variables may result in more than one score. When this occurs only the maximum value is shown in Table 7 . 
Table 7. Sensitivity of different Coastal Vulnerability Indices to changes in risk class from high to low assignments for one to three variables.

\begin{tabular}{cccc}
\hline & \multicolumn{3}{l}{ Number of Variables Changed } \\
$\mathrm{CVI}$ & 1 & 2 & 3 \\
\hline $\mathrm{CVI}_{1}$ & 80 & 96 & 99 \\
$\mathrm{CVI}_{2}$ & 80 & 96 & 99 \\
$\mathrm{CVI}_{3}$ & 14 & 27 & 41 \\
$\mathrm{CVI}_{4}$ & 80 & 96 & 99 \\
$\mathrm{CVI}_{5}$ & 56 & 80 & 81 \\
$\mathrm{CVI}_{6}^{2}$ & 16 & 32 & 48 \\
\hline
\end{tabular}

This table indicates that $\mathrm{CVI}_{1}, \mathrm{CVI}_{2}$, and $\mathrm{CVI}_{4}$ are highly sensitive to variations in the classification of the risk variables, whereas $\mathrm{CVI}_{3}$ is insensitive to classification variations. $\mathrm{CVI}_{5}$ seems to be relatively insensitive to variations in one risk factor, while still being able to produce usable results when differences occur within several factors. $\mathrm{CVI}_{6}$ showed lower sensitivity overall to misclassification errors and missing data. Thus, $\mathrm{CVI}_{6}$ may be preferable to $\mathrm{CVI}_{5}$. An expanded version of $\mathrm{CVI}_{6}$ was used in Gornitz et al. (1994).

By way of illustration, $\mathrm{CVI}_{5}$ was calculated for the gridded data groups within this NDP, and a histogram of the data values was constructed. Based on the histogram, three risk classes were developed (i.e., low-, moderate-, and high-risk based on 33 percentile ranges). Low risk class values are those values less than 11 , moderate risk values range from 11 to 22 , and high risk values are greater than 22 .

The aforementioned risk class assignments for the U.S. West coastline are illustrated in Figure 8. 
Fig. 8. Example of how the Coastal Vulnerability Index $\left(\mathrm{CVI}_{5}\right)$ may be used to identify high-risk coastlines along the U.S. West Coast.

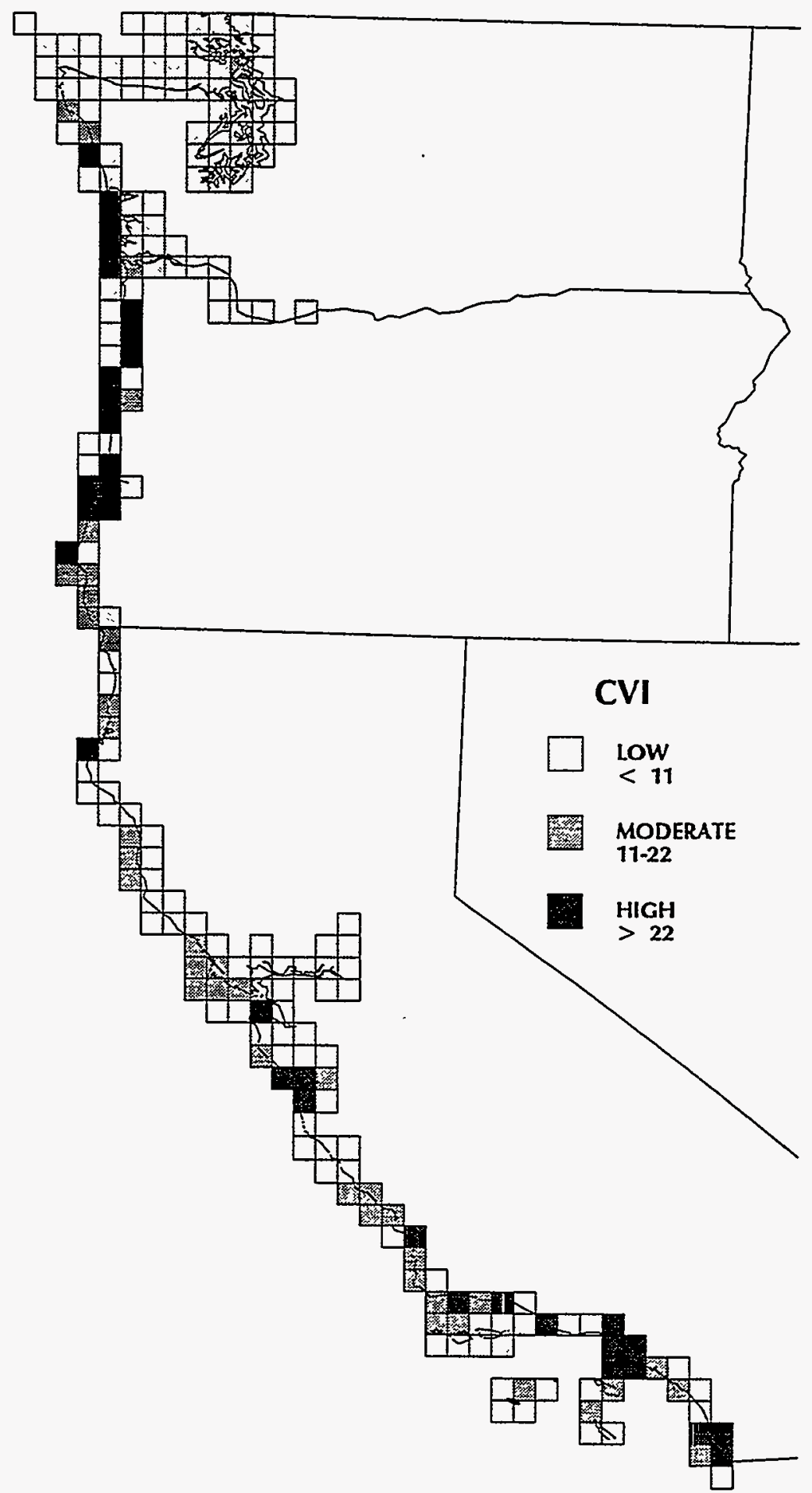


$\mathrm{CVI}_{5}$ values range from 0.87 to 58.55 along the U.S. West Coast, with a mean value of 10.51 . Although rugged relief and erosion resistant substrate reduce the overall vulnerability rating of the West coast, the highly variable topography and geologic/geomorphic setting produce a number of exceptions. Some examples are the barrier beaches of Oregon and Washington, the Monterey Bay area including Santa Cruz, Pismo Beach, and the following cities: San Francisco, Santa Barbara,

- Santa Monica, and San Diego. A majority of the high risk areas face west and, as a result, are directly impacted by large ocean waves. This implies that climatic variables such as wind direction and fetch length may be one of the primary forcing factors for erosion on the West coast.

\section{Limitations and Restrictions of the Data}

Because of the spatial extent of this data base, the period of record, sampling frequency, and scale of the source documents varied. The use of long-term averages and the use of the $0.25^{\circ}$ grid cell as the spatial scale for these data has minimized the error that may have been introduced when these data sources were integrated into a single data base with uniform formats and scales.

The geologic data were classified in terms of an ordinal scale based on the relative hardness of minerals comprising the rock, and derived from state geologic maps. Since these characteristics cannot be deduced from the geologic maps alone, field checking would be required to obtain a more detailed classification than that used in this data set.

The sea-level trend variables (derived from long-term tide-gauge records) may have significant error due to the interpolation methods used. The tide-gauge records used for calculating the sea level trends on the West Coast were obtained from the records of the Permanent Service for Mean Sea Level (Pugh et al. 1987). These records have been examined and contain no identifiable errors, are of very high quality, and have been used in several sea-level-rise studies (Douglas 1991). However, the sparse station network has made it necessary to calculate the sea-level-trend variables for intervening grid cells by calculating a slope line between the two closest adjacent stations. Confidence in the accuracy of the local subsidence variable and the relative and corrected sealevel-trend variables estimated with this method decreases as the distance between grid cells that are missing data and adjacent tide-gauge stations increases. For the U.S. East and West coasts, it was found that if the distance from a grid cell with no data to the nearest two long-term gauge stations (i.e., that are east and west or north and south of the no-data grid cell) exceeds $-350 \mathrm{~km}$ (i.e., at that distance the $\mathrm{r}^{2}$ of adjacent stations is 0.717), then the sea-level-trend variable derived for the no-data grid cell may be erroneous. However, the highly variable topography, geology, and geomorphology of the West Coast, together with the active tectonism suggest that interpolations of the sort proposed here should be used with caution. Whenever feasible, local subsidence (or uplift) data should be used. Some longer-term geologic trends are listed in Appendix D.

Should the user choose to apply the methods and data illustrated in Appendix $D$ to calculate a revised local subsidence trend variable, it will be necessary to reassign a risk value as well, before calculating a coastal vulnerability index.

The statistical summations given within this NDP reflect $0.25^{\circ}$ latitude by $0.25^{\circ}$ longitude gridded data values and may vary slightly from those given in publications by the contributors. Another discrepancy is that the tide tables used in this document are for 1992 (NOS 1992) as were those used in NDP-043B, while the East Coast, NDP-043A tide tables were for 1988 (NOS 1988).

The coastal hazards data base presented here for the U.S. West Coast omits several factors that 
may be important when determining the risk of a given area to inundation or erosion. Other variables that may be useful in the risk assessment process are: storm surge, storm frequencies, storm intensities, presence of exposed infrastructure, coastal population density, the role of sediment transport, and the risk of saltwater intrusion (Titus et al. 1991, Snedaker and Sylva 1987). Several studies have been done that consider several of these factors. Gornitz et al. (1994) conducted a pilot study with an expanded CVI based on the seven relative risk variables in this NDP and six climatic factors derived from Birdwell and Daniels (1991). A copy of the results of this study is reprinted in Appendix D.

\section{Data Checks Performed by CDIAC}

An important part of the data packaging process at the CDIAC is the quality assurance (QA) of the data before its distribution. Data received at CDIAC are rarely in perfect condition for immediate distribution, regardless of source. CDIAC staff members examine the data for completeness, reasonableness, and accuracy. The QA process is an important component in the value-added concept of assuring accurate, usable information for researchers. The following summarizes the QA checks performed on the various data groups presented in this document:

(1) Data variables obtained from primary data sources were double-entered into flat ASCII computer files and proofed for discrepancies. The generated machine-readable data files were then uploaded to a Sun workstation and read into SAS ${ }^{\mathrm{TM}}$. The SAS ${ }^{\mathrm{TM}}$ PROC COMPARE procedure was used to overlay the two versions and identify differences. All differences were then checked against the original data source, and any necessary corrections made.

2) Data variables obtained from maps (e.g., geology) were classified and transferred to coastal segments on working maps of the coastline. The working maps were then digitized, plotted at a large scale, and compared with the original working maps and data sources. All identified discrepancies were then corrected.

(3) Maximum, minimum, and mean values were generated for all data variables and checked for reasonableness against predetermined thresholds.

(4) The data values for each data variable were mapped using the 1:2,000,000 digitized USGS line-segment coverage of the U.S. West Coast as a backdrop to check for outliers and identifiable discrepancies. The identified data items were then recalculated, and corrected if necessary. 


\section{How to Obtain the Data Package}

This document describes the contents of a coastal hazards data base intended for use by vector or raster GISs or non-GIS data base systems. The computerized data are available on Exabyte 8-mm tapes, QIC quarter-inch tape cartridges, or floppy diskettes. These data are also available via the File Transfer Protocol (FTP) and the World Wide Web at http://cdiac.esd.ornl.gov. Requests for this data package should be addressed to:

Carbon Dioxide Information Analysis Center

Oak Ridge National Laboratory

Post Office Box 2008

Oak Ridge, Tennessee 37831-6335, U.S.A.

The media and/or documentation can be ordered by telephone, fax or electronic mail using:

Telephone: (423) 574-0390 or (423) 574-3645; FAX: (423) 574-2232

INTERNET: CDIAC@ORNL.GOV

The computerized data files may be acquired over the internet from CDIAC's Anonymous FTP service as follows:

- $\quad$ FTP to CDIAC.ESD.ORNL.GOV (128.219.24.36)

- Enter "ftp" as the User-ID.

- Enter your electronic mail address as the password (e.g., BIRDK@ornl.gov)

- Change to the directory pub/ndp043c (or ndp043a for the East Coast, ndp043b for the Gulf Coast).

- Set FTP to ASCII mode by using the ASCII command (i.e., "ascii").

- Acquire the ASCII data files (i.e., "mget *.asc").

- $\quad$ Acquire the FORTRAN files (i.e., "mget *.for").

- $\quad$ Acquire the SAS ${ }^{\mathrm{TM}}$ files (i.e., "mget *.sas").

- Set FTP to binary mode by using the Binary command (i.e., "binary").

- $\quad$ Acquire the binary $\mathrm{Arc} / \mathrm{Info}^{\mathrm{TM}}$ export files (i.e., "mget *.e00").

- Exit the system by using the FTP quit command (i.e., "quit"). 


\section{References and Data Sources}

\subsection{Citations}

Atwater, B. F., 1987. Evidence for great Holocene earthquakes along the outer coast of Washington State. Science. 236: 942-944.

Atwater, B. F., Stuiver, M., and D. K. Yameguchi. 1991. Radiocarbon test of earthquake magnitude at the Cascadia subduction zone. Nature. 353: 156-158.

Birdwell, K. R., and R. C. Daniels. 1991. A Global Geographic Information System Data Base of Storm Occurrences and Other Climatic Phenomena Affecting Coastal Zones. ORNL/CDIAC40, NDP-35. Oak Ridge National Laboratory, Oak Ridge, Tennessee.

Case, R. A., and M. Mayfield, 1990. Atlantic hurricane season of 1989. Monthly Weather Review. 118: 1165-1177.

Corson, W. D., C. E. Abel, R. M. Brooks, P. D. Farrar, B. J. Groves, J. B. Payne, D. S. McAreny, and B.A. Tracy. 1987. Pacific Coast Hindcast Phase II Wave Information. WIS Report 16, U.S. Army Corp of Engineers, Vicksburg, Mississippi.

Darienzo, M. E., and C. D. Peterson, 1990. Episodic tectonic subsidence of late-Holocene salt marsh sequences in Netarts Bay, Oregon, Central Cascadia Margin. Tectonics. 9: 1-22.

Darienzo, M. E., C. D. Peterson, and C. Clough, 1994. Stratigraphic evidence for great subduction-zone earthquakes at four estuaries in northern Oregon, U.S.A. J. Coast. Res., 4:850-876.

Dolan, R., B. Hayden, and M. Vincent. 1975. Classification of coastal landform of the Americas. Zeitschrift fuer Geomorphologic, Supp. Bull., 22:72-88.

Dolan, R., B. Hayden, P. May, and S. May. 1980. The reliability of shoreline change measurements from aerial photographs. Shore and Beach, 48:22-29.

Dolan, R., B. Hayden, and S. May. 1983. Erosion of the U.S. shorelines. In P. D. Komar (ed.), CRC Handbook of Coastal Processes and Erosion. CRC Press, Inc., Boca Raton, Florida.

Dolan, R., H. Lins, and B. Hayden. 1988. Mid-Atlantic coastal storms. J. of Coastal Res., 4:417-433.

Dolan, R., S. J. Trossbach, and M. K. Buckley. 1989. Patterns of erosion along the Atlantic coast. pp. 17-22. Coastal Zone '89. ASCE.

Douglas, B. C. 1991. Global sea-level rise. J. of Geophys. Res. 96C:6981-92.

Emanuel, K. A. 1988. The maximum intensity of hurricanes. J. of Atmos. Sci. 45:1143-55. 
Emery, K. O. and D. G. Aubrey. 1991. Sea Levels, Land Levels, and Tide Gauges. Springer Verlag, New York, New York.

Gornitz, V. 1988a. Development of a global coastal hazards data base: Annual technical report. Oak Ridge National Laboratory, Oak Ridge, Tennessee.

Gornitz, V. 1988b. Development of a global coastal hazards data base: Annual technical report. Oak Ridge National Laboratory, Oak Ridge, Tennessee.

Gornitz, V. 1990. Vulnerability of the East Coast, U.S.A. to future sea-level rise. Proceedings of the Skagen Symposium, J. of Coastal Res. Special Issue No. 9.

Gornitz, V. 1991. Development of a global coastal hazards data base: Annual technical report. Oak Ridge National Laboratory, Oak Ridge, Tennessee.

Gornitz, V. and P. Kanciruk. 1989. Assessment of global coastal hazards from sea-level rise. Coastal Zone '89. pp. 1345-59. In Proceedings of Sixth Symposium on Coastal and Ocean Management. ASCE, Charleston, South Carolina,.pp. 1345-1359.

Gornitz, V. and S. Lebedeff. 1987. Global sea-level changes during the past century. In Sea-Level Change and Coastal Evolution. SEPM Special Publication No. 41.

Gornitz, V. and L. Seeber. 1990. Vertical crustal movements along the East Coast, North America, from historic and late Holocene sea level data. Tectonophysics. 178:127-150.

Gornitz, V. and T. W. White. 1994. A coastal hazards data base for the U.S. Gulf Coast. ORNL/CDIAC-60, NDP-043B. Oak Ridge National Laboratory, Oak Ridge, Tennessee.

Gornitz, V. and T. W. White. 1992. A coastal hazards data base for the U.S. East Coast. ORNL/CDIAC-45, NDP-043A. Oak Ridge National Laboratory, Oak Ridge, Tennessee.

Gornitz, V. and T. W. White. 1991. The global coastal hazards data base. pp. 214-224. In Future Climate Studies and Radio-Active Waste Disposal, Safety Studies. Norwich, England.

Gornitz, V., T. W. White, and R. M. Cushman. 1991. Vulnerability of the U.S. to future sea-level rise. Coastal Zone '91. pp. 2354-68. In Proceedings of Seventh Symposium on Coastal and Ocean Management. ASCE.

Gornitz, V., R. C. Daniels, T. W. White, and K. R. Birdwell. 1994. The Development of a Coastal Risk Assessment Database for the U.S. Southeast: Erosion and Inundation from Sea-Level Rise. pp. 327-338. In Coastal Hazards: Perception, Susceptibility, and Mitigation. C. W. Finkle, Jr. (ed.). J. of Coastal Res. Special Issue No. 12, Fort Lauderdale, Florida..

Hubertz, J. M., B. A. Tracy, J. B. Payne, and A. Cialone. 1992. Verification of Pacific Ocean Deepwater Hindcast Wave Information. WIS Report 29, CERC, Vicksburg, Mississippi.

Houghton, J. T., L. G. Meira Filho, B. A. Callender, N. Harris, A. Kattenberg, and K. Maskell, eds., 1996. Climate Change 1995: The Science of Climate Change, Cambridge University Press, New York, New York. 
Houghton, J. T., G. J. Jenkins, and J. J. Ephraums. 1990. Climate Change: The IPCC Scientific Assessment. Cambridge University Press, New York, New York.

Jensen, R. E., J. M. Hubertz, and J. B. Payne. 1989. Pacific Ocean Hindcast Phase III Wave Information. WIS Report 17, CERC, Vicksburg, Mississippi.

May, S. K., W. H. Kimball, N. Grady, and R. Dolan. 1982. CEIS: The coastal erosion information system. Shore and Beach. 50:19-25.

May, S. K., R. Dolan, and B. P. Hayden. 1983. Erosion of U.S. shorelines. EOS. 65:521-523.

Muhs, D. R., R. M. Thorson, J. J. Clague, W. H. Mathews, P. F. McDowell, and H. M. Kelsey. 1987. Pacific Coast and Mountain System, pp. 517-581. In Geomorphic Systems of North America, Vol. 2, W. L. Graf (ed.). Geologic Society of America, Boulder, Colorado.

National Ocean Service (NOS). 1988. Tide Tables 1988 -High and Low Water Predictions, East Coast of North and South America. NOAA, U.S. Government Printing Office, Washington, D.C.

NOS. 1992. Tide Tables 1992 -High and Low Water Predictions, West Coast of North and South America. NOAA, U.S. Government Printing Office, Washington, D.C.

Pugh, D. T., N. E. Spencer, and P. L. Woodworth. 1987. Data Holdings of the Permanent Service for Mean Sea Level. Bidston Observatory, England.

Shaw, J., R. B. Taylor, D. L. Forbes, M.-H. Ruz, and S. Solomon. 1994. Sensitivity of the Canadian Coast to Sea-Level Rise. Open File 2825, Geological Survey of Canada, Dartmouth, Nova Scotia.

Spencer, N. E., and P. L. Woodworth, 1993. Data Holdings of the Permanent Service for Mean Sea Level (Nov. 1993), Birkenhead, U.K., 81 pp.

Snedaker, S. C., and D. P. Sylva. 1987. Impacts of climate change on coastal resources: Implications for property values, commerce, estuarine environments, and fisheries, with special reference to South Florida. In Proceedings of the Symposium on Climate Change in the Southern United States: Future Impacts and Present Policy Issues, M. Meo (ed.). U.S. Environmental Protection Agency, Office of Policy, Planning, and Evaluation, Washington, D.C..

Titus, J. G., R. A. Park, S. P. Leatherman, J. R. Weggel, M. S. Greene, P. W. Mausel, S. Brown, and C. Gaunt. 1991. Greenhouse effect and sea level rise: The cost of holding back the sea. Coastal Manage. 19:171-204.

Warrick, R. A., E. M. Barrow, and T. M. L. Wigley, 1993. Climate and Sea Level Change: Observations, Projections, and Implications. Cambridge University Press, New York, New York.

Woodworth, P. L., 1995. PSMSL Annual Report for 1995. 
U. S. Department of Energy. 1987. Carbon dioxide and climate: Summaries of research in FY 1987. DOE/ER-0347, Dist. Category UC-11, Washington, D.C.

U. S. Department of Energy. 1988. Carbon dioxide and climate: Summaries of research in FY 1988. DOE/ER-0385, Dist. Category UC-11, Washington, D.C.

U. S. Department of Energy. 1989. Carbon dioxide and climate: Summaries of research in FY 1989. DOE/ER-0425, Dist. Category UC-402, Washington, D.C.

U. S. Department of Energy. 1990. Carbon dioxide and climate: Summaries of research in FY 1990. DOE/ER-0470T, Dist. Category UC-402, Washington, D.C.

U. S. Department of Energy. 1991. Carbon dioxide and climate: Summaries of research in FY 1991. DOE/ER-0508T, Dist. Category UC-402, Washington, D.C.

U. S. Department of Energy. 1992. Global Change Research: Summaries of Research in FY 1992. DOE/ER-0565T, Dist. Category UC-402, Washington, D.C.

U. S. Department of Energy. 1993. Global Change Research: Summaries of Research in FY 1993. DOE/ER-0597T, Dist. Category UC-402, Washington, D.C.

\subsection{Digital Elevation Data}

Defense Mapping Agency. 1-Degree DEM Data. ESIC, Reston, Virginia.

National Geophysical Data Center. ETOPO5 Gridded World Elevations. Boulder, Colorado.

\subsection{Geology Maps}

Bennison, A. P. 1973. Geological highway map of the Pacific Northwest region: Washington, Oregon (Idaho in part). American Association of Petroleum Geologists with the cooperation of the United States Geological Survey, Tulsa, Oklahoma.

Feray, D. E. 1968. Geological highway map of the Pacific Southwest region: California, Nevada. American Association of Petroleum Geologists with the cooperation of the United States Geological Survey, Tulsa, Oklahoma.

Greene, H. G. and M. P. Kennedy (eds). 1986-1989. California continental margin geologic map series. Maps 1a-7a. California Division of Mines and Geology. Sacramento, California.

Schuster, J. E. and K. G. Ikerd. 1992. Geologic map of Washington. Washington State Department of Natural Resources, Division of Geology and Earth Resources, Olympia, Washington.

Walker, G. W. and N. S. Macload. 1991. Geologic map of Oregon. U.S. Geological Survey, Reston, Virginia. 


\subsection{Topographic Maps}

\section{Washington}

U.S. Geological Survey. 1968. Cape Flattery. 1:250,000 series (topographic), Reston, Virginia.

U.S. Geological Survey. 1974. Victoria. 1:250,000 series (topographic), Reston, Virginia.

U.S. Geological Survey. 1968. Copalis Beach. 1:250,000 series (topographic), Reston, Virginia.

U.S. Geological Survey. 1974. Seattle. 1:250,000 series (topographic), Reston, Virginia.

U.S. Geological Survey. 1974. Hoquiam. 1:250,000 series (topographic), Reston, Virginia.

\section{Oregon}

U.S. Geological Survey. 1974. Vancouver. 1:250,000 series (topographic), Reston, Virginia.

U.S. Geological Survey. 1977. Salem. 1:250,000 series (topographic-bathymetric), Reston, Virginia.

U.S. Geological Survey. 1973. Coos Bay. 1:250,000 series (topographic), Reston, Virginia.

\section{California}

U.S. Geological Survey. 1977. Crescent City. 1:250,000 series (topographic-bathymetric), Reston, Virginia.

U.S. Geological Survey. 1977. Eureka . 1:250,000 series (topographic-bathymetric), Reston, Virginia.

U.S. Geological Survey. 1979. Redding. 1:250,000 series (topographic), Reston, Virginia.

U.S. Geological Survey. 1979. Ukiah. 1:250,000 series (topographic-bathymetric), Reston, Virginia.

U.S. Geological Survey. 1980. Santa Rosa. 1:250,000 series (topographic-bathymetric), Reston, Virginia.

U.S. Geological Survey. 1970. Sacramento. 1:250,000 series (topographic), Reston, Virginia.

U.S. Geological Survey. 1980. San Francisco. 1:250,000 series (topographic), Reston, Virginia.

U.S. Geological Survey. 1969. San Jose. 1:250,000 series (topographic), Reston, Virginia.

U.S. Geological Survey. 1974. Monterey. 1:250,000 series (topographic-bathymetric), Reston, Virginia. 
U.S. Geological Survey. 1979. San Luis Obispo. 1:250,000 series (topographic-bathymetric), Reston, Virginia.

U.S. Geological Survey. 1969. Santa Maria. 1:250,000 series (topographic), Reston, Virginia.

U.S. Geological Survey. 1975. Los Angeles. 1:250,000 series (topographic-bathymetric), Reston, Virginia.

U.S. Geological Survey. 1978. Long Beach. 1:250,000 series (topographic-bathymetric), Reston, Virginia.

U.S. Geological Survey. 1978. San Clemente Island. 1:250,000 series (topographic-bathymetric), Reston, Virginia.

U.S. Geological Survey. 1979. Santa Ana. 1:250,000 series (topographic-bathymetric), Reston, Virginia.

U.S. Geological Survey. 1978. San Diego. 1:250,000 series (topographic-bathymetric), Reston, Virginia. 

. 
PART 2: INFORMATION ABOUT THE COMPUTERIZED DATA FILES 



\section{Contents of the Computerized Data Files}

The following table lists the 21 data files distributed by the Carbon Dioxide Information Analysis Center (CDIAC) along with this documentation. Each listing includes the file number; a brief description including the file name; the number of number of records, file size, and record length. These files are available on 8-mm tapes, quarter inch tape cartridges, IBM-formatted floppy diskettes, and over the Internet using the File Transfer Protocol (FTP) from CDIAC's anonymous FTP area or through the CDIAC world wide web homepage at http://cdiac.esd.ornl.gov.

Table 8. List and description of the NDP-043C data files.

\begin{tabular}{|c|c|c|c|c|}
\hline \multicolumn{2}{|c|}{$\begin{array}{l}\text { File number, } \\
\text { description, and name }\end{array}$} & $\begin{array}{l}\text { File } \\
\text { size (bytes) }\end{array}$ & $\begin{array}{l}\text { Number of } \\
\text { records }\end{array}$ & $\begin{array}{l}\text { Record } \\
\text { length }\end{array}$ \\
\hline 1. & $\begin{array}{l}\text { General descriptive information } \\
\text { file (NDP043C.TXT) }\end{array}$ & 281,842 & 5265 & 85 \\
\hline 2. & $\begin{array}{l}\text { FORTRAN retrieval program } \\
\text { to read and print file } 5 \\
\text { (WCGRID.FOR) }\end{array}$ & 4,050 & 50 & 80 \\
\hline 3. & $\begin{array}{l}\text { SAS TM code to read and print } \\
\text { file } 5 \text { (WCGRID.SAS) }\end{array}$ & 729 & 9 & 80 \\
\hline 4. & $\begin{array}{l}\text { Gridded data for the } 22 \text { original } \\
\text { data variables, all } 7 \text { data sets } \\
\text { (Arc/Infor }{ }^{\mathrm{TM}} \text { export file, } \\
\text { WCGRID.E00) }\end{array}$ & $3,786,102$ & 46,742 & 80 \\
\hline 5. & $\begin{array}{l}\text { Gridded data for the } 22 \text { original } \\
\text { data variables, all } 7 \text { data sets } \\
\text { (flat ASCII file, WCGRID.ASC) }\end{array}$ & 440,640 & 5,440 & 80 \\
\hline 6. & $\begin{array}{l}\text { FORTRAN retrieval program } \\
\text { to read and print file } 9 \\
\text { (WCRISK.FOR) }\end{array}$ & 2,916 & 36 & 80 \\
\hline 7. & $\begin{array}{l}\text { SAS }^{\mathrm{TM}} \text { code to read and print } \\
\text { file } 9 \text { (WCRISK.SAS) }\end{array}$ & 486 & 6 & 80 \\
\hline 8. & $\begin{array}{l}\text { Gridded data for the } 7 \text { relative } \\
\text { risk variables: elevation, geology } \\
\text { geomorphology, sea-level trends, } \\
\text { erosion/accretion rates, tidal ranges, } \\
\text { and wave heights (Arc/Info }{ }^{\mathrm{TM}} \\
\text { export file, WCRISK.E00) }\end{array}$ & $2,682,396$ & 33,116 & 80 \\
\hline
\end{tabular}


Table 8. (continued)

\begin{tabular}{llll}
\hline $\begin{array}{l}\text { File number, } \\
\text { description, and name }\end{array}$ & $\begin{array}{l}\text { File } \\
\text { size (bytes) }\end{array}$ & $\begin{array}{l}\text { Number of } \\
\text { records }\end{array}$ & $\begin{array}{l}\text { Record } \\
\text { length }\end{array}$ \\
\hline
\end{tabular}

9. Gridded data for the 7 relative risk variables: elevation, geology, geomorphology, sealevel trends, erosion/accretion rates, tidal ranges, and wave heights (flat ASCII file, WCRISK.ASC)

10. FORTRAN retrieval program to read and print file 13

(WCLINE.FOR)

11. SAS $S^{\mathrm{TM}}$ code to read and print file 13 (WCLINE.SAS)

12. $1: 2,000,000$ digitized line segment data for the 22 original variables and 7 relative risk variables.

(Arc/Info ${ }^{\mathrm{TM}}$ export file, WCLINE.EO0)

13. $1: 2,000,000$ digitized line segment data for the 22 original variables and 7 relative risk variables. (flat ASCII file, WCLINE.ASC)

14. FORTRAN retrieval program to read and print file 17

(WCPOINT.FOR)

15. SAS ${ }^{\mathrm{TM}}$ code to read and print File 17 (WCPOINT.SAS)

16. Supplemental point data for the sea-level and tidal range data sets (Arc/Info ${ }^{\mathrm{TM}}$ export file, WCPOINT.E00)

17. Supplemental point data for the sea-level and tidal range data sets (flat ASCII file, WCPOINT.ASC) 
Table 8. (concluded)

\begin{tabular}{llll}
$\begin{array}{l}\text { File number, } \\
\text { description, and name }\end{array}$ & $\begin{array}{l}\text { File } \\
\text { size (bytes) }\end{array}$ & $\begin{array}{l}\text { Number of } \\
\text { records }\end{array}$ & $\begin{array}{l}\text { Record } \\
\text { length }\end{array}$ \\
\hline
\end{tabular}

18. FORTRAN retrieval program to read and print file 21

(WCOAST.FOR)

19. SAS $^{\mathrm{TM}}$ code to read and print

file 21 (WCOAST.SAS)

20. 1:2,000,000 digitized line segment coverage of the U.S. West Coast (Arc/Info ${ }^{\mathrm{TM}}$ export file, WCOAST.E00)

21. $1: 2,000,000$ digitized line segment coverage of the U.S. West Coast

(flat ASCII file, WCOAST.ASC)

\section{Note:}

Arc/Info ${ }^{\mathrm{MM}}$ export files (Version 7) are coverages converted to flat ASCI, fixed-block, files for data transfer purposes. The IMPORT command in Arc/Info ${ }^{\mathrm{TM}}$ must be used to enter these files into your system. Arc/Info ${ }^{\mathrm{TM}}$ is a registered trademark of the Environmental Systems Research Institute, Inc., Redlands, CA 92372.

SAS ${ }^{\mathrm{TM}}$ is a registered trademark of the SAS Institute, Inc., Cary, NC 27511-8000. 


\section{Contents of the Descriptive File}

The following is a listing of the general descriptive information file (ndp043c.txt) distributed by CDIAC as part of this NDP. This file provides variable descriptions, formats, units, and other pertinent information about each file associated with this coastal hazards data base.

\section{Title of the Data Base}

\section{A Coastal Hazards Data Base for the U.S. West Coast}

\section{Contributors}

\section{Vivien M. Gornitz}

Center for Climate Systems Research, Columbia University

Goddard Institute for Space Studies, National Aeronautics and Space Administration

New York, New York

\section{Tammy W. Beaty}

Carbon Dioxide Information Analysis Center, Environmental Sciences Division

Oak Ridge National Laboratory

Oak Ridge, Tennessee

\section{Richard C. Daniels}

Energy, Environment and Resources Center, The University of Tennessee

Knoxville, Tennessee

Current affiliation:

Shorelands and Water Resources Program, Water Division, Department of Ecology

Olympia, Washington

\section{Scope of the Data}

The 29 data variables within A Coastal Hazards Data Base for the U.S. West Coast, and the corresponding coastal vulnerability indices that may be derived from algorithms listed within this NDP, may be used by coastal planning, research, and management agencies to identify shorelines at risk from coastal erosion and inundation. This data base should be used to identify areas where further study is necessary. In addition, these data may be used in combination with appropriate climatological data (e.g., Birdwell and Daniels 1991) to identify coastal areas that are vulnerable to coastal erosion and inundation from sea-level rise or storm surge (e.g., Gornitz et al. 1996).

This data base consists of the following data sets: elevation, bedrock geology, geomorphology, sea- level trends, horizontal shoreline movements (erosion/accretion), tidal ranges, and wave heights. For several of these data sets, minimum, mean, and maximum data values are available. These data variables may be divided into two basic classes, one that measures erosion potential and one that is related to inundation risk. The erosion risk of each coastal grid cell or line segment may be determined based on geology, geomorphology, shoreline displacement, tidal ranges and wave heights, while the inundation risk may be estimated based on sea-level trends and elevations. 
Seven of the 29 data variables are classified versions of other variables within this data base. The seven classified risk variables contain "risk values" of one to five for each coastal grid cell and line segment in this data base. These risk variables may be used to calculate a coastal vulnerability index (CVI) to identify areas on the West Coast that are vulnerable to sea-level rise or coastal erosion.

\section{Data Formats}

This data base has been divided into five data groups. Each of these five data groups is provided in two different data formats. The first format is designed for use by the Arc/Info ${ }^{\mathrm{TM}}$ Geographic Information System (GIS). This format stores the data as polygons (e.g., WCGRID and WCRISK), arcs (e.g., WCLINE and WCOAST), or as points (e.g., WCPOINT). The second format contains comparable data that have been converted into flat ASCII data files for use by raster GISs or nonGIS data base systems.

The first two data groups are registered to a $0.25^{\circ}$ latitude by $0.25^{\circ}$ longitude grid. The first, WCGRID (Files 4 and 5) provides the 22 original data variables, while the second data group, WCRISK (Files 8 and 9) provides the seven relative risk variables.

The third data group is registered to line segments derived from a 1:2,000,000 digitized U.S. West Coast coastline. WCLINE (Files 12 and 13) provides 29 data variables (i.e., the 22 original and the seven relative risk data variables).

The fourth data group, WCPOINT (Files 16 and 17), provides the source information used in the development of the tidal-range and sea-level trends data sets. Data variables included in this data group are station names/numbers, record lengths, and longitude/latitude locations of the actual data point. These data represent the physical location of the occurring data point, and will allow the precise location of each station used in calculating the gridded tidal-range and sea-level-rise data variables within the $0.25^{\circ}$ grid cells of data groups WCGRID and WCRISK to be identified.

Finally, the last group contains a 1:2,000,000 digitized coastline of the U.S. West Coast, WCOAST (files 20 and 21). These line segments are identical to those found in data group WCLINE; however, no data values are provided with this data group.

A description of the contents of each of the data groups and files included with this data base follows:

(1) WCGRD: Gridded polygon data for the 22 original data variables. Data sets contained in this group include elevation, geology, geomorphology, sea-level trend, shoreline displacement (erosion/accretion), tide range, and wave heights.

(2) WCRISK: Gridded polygon data for the seven classified risk variables. The risk variables are classified versions of the following original variables: mean coastal elevation, geology, geomorphology, local subsidence trend, mean shoreline displacement, mean tidal range, and maximum significant wave height.

(3) WCLINE: 1:2,000,000 digitized line segment data for the U.S. West Coast containing the 29 data variables (i.e., the 22 original data variables and the seven classified risk 
variables).

(4) WCPOINT: Point data for the stations used in calculating the sea-level trend and tiderange data sets. Data include station names/numbers, record length, latitude/longitude location, and mean and maximum data values (when available).

WCOAST: $1: 2,000,000$ digitized coastline of the U.S. West Coast. The coastline was extracted from a digitized map of the United States compiled by the U.S. Geological Survey.

To improve the portability of the information in the data files, FORTRAN and SAS ${ }^{\mathrm{TM}}$ input/output routines have been included with this data base for each of the flat ASCII data files. These input/output routines are intended to be used to read/write the data values contained in the flat ASCII data files [containing the gridded data base, the original point data (for the sea-level trend and tide-range variables), and the digitized U.S. West coastline].

The data groups in this data base are available as exported Arc/Info ${ }^{\mathrm{TM}}$ coverages (Version 7). The export files must be read into an Arc/Info ${ }^{\text {TM }}$ GIS using the IMPORT command with the COVER option after uploading the files onto a computer. These files are in a GEOGRAPHIC projection, which means the coverages are projected in a spherical reference grid using latitude and longitude coordinates that are stored in decimal degrees (DD). The flat ASCII files contain an identical version of this data base.

The gridding method used in this data base consists of $0.25^{\circ}$ latitude by $0.25^{\circ}$ longitude grid cells. These cells cover the area defined by the following coordinates: $126^{\circ} \mathrm{W}, 32^{\circ} \mathrm{N} ; 126^{\circ} \mathrm{W}, 49^{\circ} \mathrm{N}$; $116^{\circ} \mathrm{W}, 49^{\circ} \mathrm{N}$; and $116^{\circ} \mathrm{W}, 32^{\circ} \mathrm{N}$. The origin of the grid is at $126^{\circ} \mathrm{W}, 32 \mathrm{~N}$, and grid identifiers increase from left to right, bottom to top. The data contained within each grid cell is an average for the entire grid cell. The grid cell identification number is located in the center of each cell and although it is not the physical location of each data value, it represents averages for all data points located within the cell.

The flat ASCII versions of the files have been provided to allow use of these data by users who do not have access to Arc/Info ${ }^{\mathrm{TM}}$ software. The format and contents of each of the flat ASCII files are described in the following section (the Arc//nfo ${ }^{\mathrm{TM}}$ coverages have the same variables and general format as described herein for the ASCII files).

\section{Data Group WCGRID:}

This data group contains gridded data for the 22 original data variables. These data variables are from the seven data sets and are as follows: mean, maximum, and minimum elevation, and the number of $5^{\prime}$ grid cells used in deriving the data values; geology; geomorphology; relative sealevel trend, long-term geologic trend (included for compatibility within this series of NDPs), corrected sea-level trend, local subsidence trend, and the years of record of the gauge stations used in calculating these values; mean, maximum, and minimum shoreline displacement, and the number of $3^{\prime}, 7.5^{\prime}$, or $15^{\prime}$ grid cells used in deriving the data values; mean and maximum tidal range, mean tide level, and the number of tidal stations used in calculating these values; 20-year mean wave height, maximum significant wave height, and the 20 -year mean wave height standard 
deviation.

The names of the Arc/Info ${ }^{\mathrm{TM}}$ coverage and flat ASCII files providing these data are WCGRID.E00 (File 4) and WCGRID.ASC (File 5), respectively. File 5 is formatted as follows:

\section{READ(5,100,END=999) ID,ELAVG,ELMAX,ELMIN,ELNUM, 1 GL,GM,SLR,SLG,SLC,SLS,SLYR READ(5,110) ERAVG,ERMAX,ERMIN,ERNUM,TRAVG, 1 TRMAX,TRLVL,TRNUM,WHAVG,WHMAX,WHSD \\ 100 FORMAT(I5,3F8.2,3I4,4F8.2,I4) \\ 110 FORMAT(3F8.2,I4,3F8.2,I4,3F8.2)}

The variables in data group WCGRID (File 5) are shown in Table 9 and are listed as they appear in the file.

Table 9. Variable formats for WCGRID.ASC (File 5).

\begin{tabular}{|c|c|c|c|c|}
\hline \multirow[b]{2}{*}{ Variable name } & \multicolumn{2}{|c|}{ Column } & \multirow[b]{2}{*}{ Variable type } & \multirow[b]{2}{*}{ Variable description } \\
\hline & Start & End & & \\
\hline $\mathrm{ID}$ & 1 & 5 & Integer & $\begin{array}{l}\text { System variable - grid cell } \\
\text { identifier. }\end{array}$ \\
\hline ELAVG & 6 & 13 & Real & $\begin{array}{l}\text { Data variable - mean } \\
\text { elevation of all positive } 5^{\prime} \\
\text { by } 5^{\prime} \text { grid cells within a } \\
\text { given } 0.25^{\circ} \text { grid cell; values } \\
\text { in meters. }\end{array}$ \\
\hline ELMAX & 14 & 21 & Real & $\begin{array}{l}\text { Data variable - maximum } \\
\text { elevation of all positive } 5^{\prime} \\
\text { by } 5^{\prime} \text { grid cells within a } \\
\text { given } 0.25^{\circ} \text { grid cell; values } \\
\text { in meters. }\end{array}$ \\
\hline ELMIN & 22 & 29 & Real & $\begin{array}{l}\text { Data variable - minimum } \\
\text { elevation of all positive } 5^{\prime} \\
\text { by } 5^{\prime} \text { grid cells within a } \\
\text { given } 0.25^{\circ} \text { grid cell; values } \\
\text { in meters. }\end{array}$ \\
\hline
\end{tabular}


Table 9.

(continued)

\begin{tabular}{|c|c|c|c|c|}
\hline \multirow[b]{2}{*}{ Variable name } & \multicolumn{2}{|c|}{ Column } & \multirow[b]{2}{*}{ Variable type } & \multirow[b]{2}{*}{ Variable description } \\
\hline & Start & End & & \\
\hline ELNUM & 30 & 33 & Integer & $\begin{array}{l}\text { Data variable - number of } 5^{\prime} \\
\text { by } 5^{\prime} \text { grid cells used in } \\
\text { calculating ELAVG, } \\
\text { ELMMN, and ELMAX for a } \\
\text { given } 0.25^{\circ} \text { grid cell. }\end{array}$ \\
\hline GL & 34 & 37 & Integer & $\begin{array}{l}\text { Data variable - ordinal value } \\
\text { indicative of the type and } \\
\text { resistance of the rocks } \\
\text { within a given } 0.25^{\circ} \text { grid } \\
\text { cell to erosion. }\end{array}$ \\
\hline GM & 38 & 41 & Integer & $\begin{array}{l}\text { Data variable - ordinal value } \\
\text { indicative of the type and } \\
\text { susceptibility of the } \\
\text { landforms within a given } \\
0.25^{\circ} \text { grid cell to inundation } \\
\text { and erosion. }\end{array}$ \\
\hline SLR & 42 & 49 & Real & $\begin{array}{l}\text { Data variable - relative sea- } \\
\text { level trend within a given } \\
0.25^{\circ} \text { grid cell calculated } \\
\text { from tide-gauge station } \\
\text { measurements; values in } \\
\text { mm/year. }\end{array}$ \\
\hline SLG & 50 & 57 & Real & $\begin{array}{l}\text { Data variable - long-term } \\
\text { geologic trend. This variable } \\
\text { is } 0.0 \text { for all } 0.25^{\circ} \text { grid cells } \\
\text { with a relative sea-level } \\
\text { trend value and is included } \\
\text { for compatibility within this } \\
\text { series of NDPs. }\end{array}$ \\
\hline SLC & 58 & 65 & Real & $\begin{array}{l}\text { Data variable - corrected } \\
\text { sea-level trend. Since the } \\
\text { geologic trend variable } \\
\text { contains values of } 0.0 \text {, this } \\
\text { variable appears identical to } \\
\text { the relative sea-level trend } \\
\text { variable; and is included } \\
\text { only for compatibility within } \\
\text { this series of NDPs. }\end{array}$ \\
\hline
\end{tabular}


Table 9. ， (continued)

\begin{tabular}{|c|c|c|c|c|}
\hline \multirow[b]{2}{*}{ Variable name } & \multicolumn{2}{|c|}{ Column } & \multirow[b]{2}{*}{ Variable type } & \multirow[b]{2}{*}{ Variable description } \\
\hline & Start & End & & \\
\hline SLS & 66 & 73 & Real & $\begin{array}{l}\text { Data variable - the local } \\
\text { uplift or subsidence trend. } \\
\text { The relative sea-level trend } \\
\text { (SLR) corrected for the } \\
\text { global eustatic rate of sea- } \\
\text { level rise (i.e., } 1.5 \mathrm{~mm} \text { /year). }\end{array}$ \\
\hline SLYR & 74 & 77 & Integer & $\begin{array}{l}\text { Data variable - years of } \\
\text { record used in estimating the } \\
\text { sea-level trend for each } \\
0.25^{\circ} \text { grid cell. }\end{array}$ \\
\hline & SECC & LINE & DS AS FOLL & 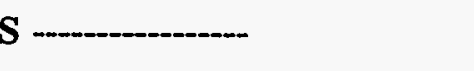 \\
\hline ERAVG & 1 & 8 & Real & $\begin{array}{l}\text { Data variable - mean long- } \\
\text { term erosion trend for a } \\
\text { given } 0.25^{\circ} \text { grid cell; values } \\
\text { in meters. }\end{array}$ \\
\hline ERMAX & 9 & 16 & Real & $\begin{array}{l}\text { Data variable - maximum } \\
\text { long-term erosion trend for a } \\
\text { given } 0.25^{\circ} \text { grid cell; values } \\
\text { in meters. }\end{array}$ \\
\hline ERMIN & 17 & 24 & Real & $\begin{array}{l}\text { Data variable - minimum } \\
\text { long-term erosion trend for a } \\
\text { given } 0.25^{\circ} \text { grid cell; values } \\
\text { in meters. }\end{array}$ \\
\hline ERNUM & 25 & 28 & Integer & $\begin{array}{l}\text { Data variable - number of } \\
3^{\prime}, 7.5^{\prime} \text {, or } 15^{\prime} \text { grid cells } \\
\text { used in calculating ERAVG, } \\
\text { ERMN, and ERMAX for a } \\
\text { given } 0.25^{\circ} \text { grid cell. }\end{array}$ \\
\hline TRAVG & 29 & 36 & Real & $\begin{array}{l}\text { Data variable - average of } \\
\text { the mean tide range for all } \\
\text { the gauge stations that occur } \\
\text { within a given } 0.25^{\circ} \text { grid } \\
\text { cell (mean tide range is the } \\
\text { difference in height between } \\
\text { mean high water and mean } \\
\text { low water); values in meters. }\end{array}$ \\
\hline
\end{tabular}


Table 9. $\quad$ (continued)

\begin{tabular}{|c|c|c|c|c|}
\hline \multirow[b]{2}{*}{ Variable name } & \multicolumn{2}{|c|}{ Column } & \multirow[b]{2}{*}{ Variable type } & \multirow[b]{2}{*}{ Variable description. } \\
\hline & Start & End & & \\
\hline TRMAX & 37 & 44 & Real & $\begin{array}{l}\text { Data variable - maximum } \\
\text { tide range measured for all } \\
\text { gauge stations that } \\
\text { occurred within a given } \\
0.25^{\circ} \text { grid cell in } 1988 \\
\text { (this value may be the } \\
\text { "spring" or "diurnal" tide } \\
\text { range, depending on } \\
\text { geographic location); } \\
\text { values in meters. }\end{array}$ \\
\hline TRLVL & 45 & 52 & Real & $\begin{array}{l}\text { Data variable - the average } \\
\text { of the mean tide levels of } \\
\text { all the gauge stations that } \\
\text { occur within a given } 0.25^{\circ} \\
\text { grid cell (mean tide level } \\
\text { is a plane midway between } \\
\text { mean low water and mean } \\
\text { high water in 1988). } \\
\text { Values were reckoned } \\
\text { from chart datums (i.e., the } \\
\text { West Coast Mean Low } \\
\text { Water Datum). }\end{array}$ \\
\hline TRNUM & 53 & 56 & Integer & $\begin{array}{l}\text { Data variable - number of } \\
\text { tide gauge stations used in } \\
\text { calculating TRAVG, } \\
\text { TRMAX, and TRLVL for } \\
\text { a given } 0.25^{\circ} \text { grid cell. }\end{array}$ \\
\hline WHAVG & 57 & 64 & Real & $\begin{array}{l}\text { Data variable - } 20 \text {-year } \\
\text { mean wave height } \\
\text { experienced within each } \\
0.25^{\circ} \text { grid cell; values in } \\
\text { meters. }\end{array}$ \\
\hline WHMAX & 65 & 72 & Real & $\begin{array}{l}\text { Data variable - maximum } \\
\text { significant wave height for } \\
\text { each } 0.25^{\circ} \text { grid cell; values } \\
\text { in meters. }\end{array}$ \\
\hline
\end{tabular}


Table 9.

(concluded)

\begin{tabular}{lllll}
\hline Variable name & \multicolumn{2}{c}{ Column } & & \\
& Start & End & Variable type & Variable description \\
\hline WHSD & 83 & Real & $\begin{array}{l}\text { Data variable - standard } \\
\text { deviation of the 20-year } \\
\text { mean wave height } \\
\text { experienced within each } \\
0.25^{\circ} \text { grid cell; values in } \\
\text { meters. }\end{array}$
\end{tabular}

Within WCGRID missing data values are identified as follows:

-9999.99 - A grid cell with real data values that is missing data for a given data variable.

9999 - A grid cell with integer data values that is missing data for a given data variable.

A value of 0.0 is a valid value for all variables. For the elevation variables $0.0 \mathrm{~m}$ indicates that land occurs within the given grid cell, but the mean elevation of this land is $<1.0 \mathrm{~m}$. If the data variables in a given data set, such as elevation, contain data and the "number" variable is set to zero (i.e., ELNUM, ERNUM, TRNUM, or SLYR), then the data variables for the given $0.25^{\circ}$ grid cell have been estimated.

\section{Data Group WCRISK:}

This data group contains gridded data for the seven classified risk variables. These risk variables are classified versions of the following original variables: mean coastal elevation, geology, geomorphology, local subsidence trend, mean shoreline displacement, mean tidal range, and maximum significant wave height.

The names of the Arc/Info ${ }^{\mathrm{TM}}$ coverage and flat ASCII files are WCRISK.E00 (File 8) and WCRISK.ASC (File 9), respectively. A summary of the format used in File 9 follows:

\section{READ(5,100,END=999) ID, ELR, GLR, GMR, LSR, \\ 1 TRR,WHR \\ 100 FORMAT(I5,714)}

The variables in data group WCRISK, listed in Table 10, are shown as they appear in File 9. 
Table 10. Variable formats for WCRISK.ASC (File 9).

\begin{tabular}{|c|c|c|c|c|}
\hline \multirow[b]{2}{*}{ Variable name } & \multicolumn{2}{|c|}{ Column } & \multirow[b]{2}{*}{ Variable type } & \multirow[b]{2}{*}{ Variable description } \\
\hline & Start & End & & \\
\hline $\mathrm{ID}$ & 1 & 5 & Integer & $\begin{array}{l}\text { System variable - grid cell } \\
\text { identifier. }\end{array}$ \\
\hline ELR & 6 & 9 & Integer & $\begin{array}{l}\text { Data variable - classified } \\
\text { version of the mean } \\
\text { elevation variable (i.e., } \\
\text { ELAVG). }\end{array}$ \\
\hline GLR & 10 & 13 & Integer & $\begin{array}{l}\text { Data variable - classified } \\
\text { version of the geology } \\
\text { variable (i.e., GL). }\end{array}$ \\
\hline GMR & 14 & 17 & Integer & $\begin{array}{l}\text { Data variable - classified } \\
\text { version of the } \\
\text { geomorphology variable } \\
\text { (i.e., GM). }\end{array}$ \\
\hline LSR & 18 & 21 & Integer & $\begin{array}{l}\text { Data variable - classified } \\
\text { version of the local } \\
\text { subsidence trend variable } \\
\text { (i.e., SLS). }\end{array}$ \\
\hline ERR & 22 & 25 & Integer & $\begin{array}{l}\text { Data variable - classified } \\
\text { version of the mean } \\
\text { erosion/accretion variable } \\
\text { (i.e., ERAVG). }\end{array}$ \\
\hline TRR & 26 & 29 & Integer & $\begin{array}{l}\text { Data variable - classified } \\
\text { version of the mean tide } \\
\text { range variable (i.e., } \\
\text { TRAVG). }\end{array}$ \\
\hline WHR & 30 & 33 & Integer & $\begin{array}{l}\text { Data variable - classified } \\
\text { version of the maximum } \\
\text { significant wave- height } \\
\text { variable (i.e., WHMAX). }\end{array}$ \\
\hline
\end{tabular}


A value of zero is used to identify missing data values within the grid cell for the risk variables. If several "no data" values occur within the same grid cell, then any calculated coastal vulnerability index that uses these relative risk factors may not accurately represent the risk of the given coastal area to sea-level rise or coastal erosion (unless some type of corrective action is taken). Grid cells that are not in the coastal zone, or are totally ocean bound, have values of zero for all seven derived risk variables.

\section{Data Group WCLINE:}

This data group contains digitized line segments obtained at a scale of $1: 2,000,000$. The coastline is composed of 1,262 line segments with lengths of $93 \mathrm{~m}$ to $88.7 \mathrm{~km}$, with an average length of $5.8 \mathrm{~km}$. Each of these line segments have 29 data variables (attributes) assigned to them (i.e., the 22 original and the seven relative risk data variables). Several of these variables have been directly transferred from WCGRID using the IDENTTTY procedure in Arc/Info ${ }^{\mathrm{TM}}$. As such, line segment lengths do not indicate the resolution of the data.

These 29 data variables are as follows: mean, maximum, and minimum elevation, the number of $5^{\prime}$ grid cells used in deriving the data values, and the elevation risk (i.e., the classified version of the mean elevation variable); geology and the geology risk (i.e., the classified version of the geology variable; geomorphology and geomorphology risk (i.e., the classified version of the geomorphology variable); relative sea-level trend, global-trend, corrected sea-level trend, local subsidence trend, the years of record of the gauge stations used in calculating these values, and the local subsidence trend risk (i.e., the classified version of the local subsidence trend variable); mean, maximum, and minimum shoreline displacement, the number of $3^{\prime}, 7.5^{\prime}$, or $15^{\prime}$ grid cells used in deriving the data values, and erosion risk (i.e., the classified version of the mean erosion/accretion variable); mean and maximum tidal range, mean tide level, the number of tidal stations used in calculating these values, and the tidal-range risk (i.e., the classified version of the mean tidal range); 20 -year mean wave height, maximum significant wave height, the 20 -year mean wave height standard deviation, and the wave-height risk (i.e., classified version of the maximum. significant wave-height variable).

The names of the Arc/Info ${ }^{\mathrm{TM}}$ coverage and flat ASCII file that provide these data variables are WCLINE.E00 (File 12) and WCLINE.ASC (File 13), respectively. File 13 is formatted as follows:

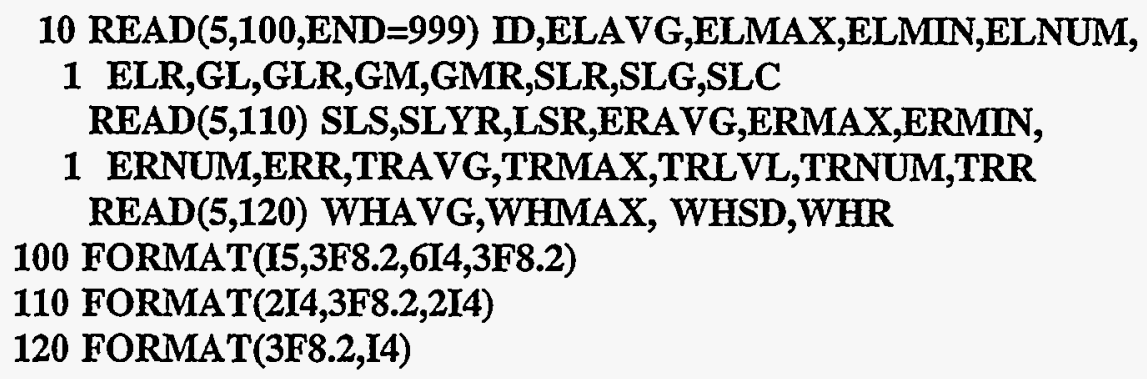

The variables in data group WCLINE (File 13) are shown in Table 11 and are listed as they appear in the file. 
Table 11. Variable formats for WCLINE.ASC (File 13).

\begin{tabular}{|c|c|c|c|c|}
\hline \multirow[b]{2}{*}{ Variable name } & \multicolumn{2}{|c|}{ Column } & \multirow[b]{2}{*}{ Variable type } & \multirow[b]{2}{*}{ Variable description } \\
\hline & Start & End & & \\
\hline ID & 1 & 5 & Integer & $\begin{array}{l}\text { System variable - grid cell } \\
\text { identifier. }\end{array}$ \\
\hline ELAVG & 6 & 13 & Real & $\begin{array}{l}\text { Data variable - mean } \\
\text { elevation of all positive } 5^{\prime} \\
\text { by } 5^{\prime} \text { grid cells within a } \\
\text { given } 0.25^{\circ} \text { grid cell; } \\
\text { values in meters. }\end{array}$ \\
\hline ELMAX & 14 & 21 & Real & $\begin{array}{l}\text { Data variable - maximum } \\
\text { elevation of all positive } 5^{\prime} \\
\text { by } 5^{\prime} \text { grid cells within a } \\
\text { given } 0.25^{\circ} \text { grid cell; } \\
\text { values in meters. }\end{array}$ \\
\hline ELMIN & 22 & 29 & Real & $\begin{array}{l}\text { Data variable - minimum } \\
\text { elevation of all positive } 5^{\prime} \\
\text { by } 5^{\prime} \text { grid cells within a } \\
\text { given } 0.25^{\circ} \text { grid cell; } \\
\text { values in meters. }\end{array}$ \\
\hline ELNUM & 30 & 33 & Integer & $\begin{array}{l}\text { Data variable - number of } \\
5^{\prime} \text { by } 5^{\prime} \text { grid cells used in } \\
\text { calculating ELAVG, } \\
\text { ELMIN, and ELMAX for } \\
\text { a given } 0.25^{\circ} \text { grid cell. }\end{array}$ \\
\hline ELR & 34 & 37 & Integer & $\begin{array}{l}\text { Data variable - classified } \\
\text { version of the mean } \\
\text { elevation variable (i.e., } \\
\text { ELAVG). }\end{array}$ \\
\hline GL & 38 & 41 & Integer & $\begin{array}{l}\text { Data variable - ordinal } \\
\text { value indicative of the } \\
\text { resistance of the rocks to } \\
\text { erosion. }\end{array}$ \\
\hline GLR & 42 & 45 & Integer & $\begin{array}{l}\text { Data variable - classified } \\
\text { version of the geology } \\
\text { variable (i.e., GL). }\end{array}$ \\
\hline
\end{tabular}


Table $11 . \quad$ (continued)

\begin{tabular}{|c|c|c|c|c|}
\hline \multirow[b]{2}{*}{ Variable name } & \multicolumn{2}{|c|}{ Column } & \multirow[b]{2}{*}{ Variable type } & \multirow[b]{2}{*}{ Variable description } \\
\hline & Start & End & & \\
\hline GM & 46 & 49 & Integer & $\begin{array}{l}\text { Data variable - ordinal } \\
\text { value indicative of the } \\
\text { susceptibility of the } \\
\text { landforms to inundation } \\
\text { and erosion. }\end{array}$ \\
\hline GMR & 50 & 53 & Integer & $\begin{array}{l}\text { Data variable - classified } \\
\text { version of the } \\
\text { geomorphology variable } \\
\text { (i.e., GM). }\end{array}$ \\
\hline SLR & 54 & 61 & Real & $\begin{array}{l}\text { Data variable - relative } \\
\text { sea-level trend calculated } \\
\text { from tide-gauge station } \\
\text { measurements. }\end{array}$ \\
\hline SLG & 62 & 69 & Real & $\begin{array}{l}\text { Data variable - long-term } \\
\text { geologic trend. This } \\
\text { variable is } 0.0 \text { for all line } \\
\text { segments with a relative } \\
\text { sea-level trend value, and } \\
\text { is included for } \\
\text { compatibility within this } \\
\text { series of NDPs. }\end{array}$ \\
\hline SLC & 70 & 77 & Real & $\begin{array}{l}\text { Data variable - corrected } \\
\text { sea-level trend. Since the } \\
\text { geologic trend variable } \\
\text { contains only values of } \\
0.0 \text {, this variable appears } \\
\text { identical to the relative } \\
\text { sea-level trend variable, } \\
\text { and is included for } \\
\text { compatibility within this } \\
\text { series of NDPs. }\end{array}$ \\
\hline
\end{tabular}


Table 11. (continued)

\begin{tabular}{|c|c|c|c|c|}
\hline \multicolumn{5}{|c|}{ Column } \\
\hline Variable name & Start & End & Variable type & Variable description \\
\hline SLS & 1 & 8 & Real & $\begin{array}{l}\text { Data variable - the local } \\
\text { uplift or subsidence trend. } \\
\text { The relative sea-level trend } \\
\text { corrected for the global } \\
\text { eustatic rate of sea-level } \\
\text { rise (i.e., } 1.5 \mathrm{~mm} / \text { year). }\end{array}$ \\
\hline SLYR & 9 & 12 & Integer & $\begin{array}{l}\text { Data variable - years of } \\
\text { record used in estimating } \\
\text { the sea-level trend for each } \\
0.25^{\circ} \text { grid cell. }\end{array}$ \\
\hline LSR & 13 & 16 & Integer & $\begin{array}{l}\text { Data variable - classified } \\
\text { version of the local } \\
\text { subsidence trend variable } \\
\text { (i.e., SLS). }\end{array}$ \\
\hline ERAVG & 17 & 24 & Real & $\begin{array}{l}\text { Data variable - mean long- } \\
\text { term erosion trend for } \\
\text { given } 0.25^{\circ} \text { grid cell; } \\
\text { values in meters. }\end{array}$ \\
\hline ERMAX & 25 & 32 & Real & $\begin{array}{l}\text { Data variable - maximum } \\
\text { long-term erosion trend for } \\
\text { a given } 0.25^{\circ} \text { grid cell; } \\
\text { values in meters. }\end{array}$ \\
\hline ERMIN & 33 & 40 & Real & $\begin{array}{l}\text { Data variable - minimum } \\
\text { long-term erosion trend for } \\
\text { a given } 0.25^{\circ} \text { grid cell; } \\
\text { values in meters. }\end{array}$ \\
\hline ERNUM & 41 & 44 & Integer & $\begin{array}{l}\text { Data variable - number of } \\
3^{\prime}, 7.5^{\prime} \text {, or } 15^{\prime} \text { grid cells } \\
\text { used in calculating } \\
\text { ERAVG, ERMIN, and } \\
\text { ERMAX for a given } 0.25^{\circ} \\
\text { grid cell. }\end{array}$ \\
\hline
\end{tabular}


Table 11. (continued)

\begin{tabular}{|c|c|c|c|c|}
\hline \multirow[b]{2}{*}{ Variable name } & \multicolumn{2}{|c|}{ Column } & \multirow[b]{2}{*}{ Variable type } & \multirow[b]{2}{*}{ Variable description } \\
\hline & Start & End & & \\
\hline ERR & 45 & 48 & Integer & $\begin{array}{l}\text { Data variable - classified } \\
\text { version of the mean } \\
\text { erosion/accretion variable } \\
\text { (i.e., ERAVG). }\end{array}$ \\
\hline TRAVG & 49 & 56 & Real & $\begin{array}{l}\text { Data variable - average of } \\
\text { the mean tide range for all } \\
\text { gauge stations that occur } \\
\text { within a given } 0.25^{\circ} \text { grid } \\
\text { cell (TRAVG is the } \\
\text { difference between mean } \\
\text { high water and mean low } \\
\text { water in 1992); values in } \\
\text { meters. }\end{array}$ \\
\hline TRMAX & 57 & 64 & Real & $\begin{array}{l}\text { Data variable - maximum } \\
\text { tide range measured for all } \\
\text { gauge stations that } \\
\text { occurred within a given } \\
0.25^{\circ} \text { grid cell in } 1992 \\
\text { (this value may be the } \\
\text { "spring" or "diurnal" tide } \\
\text { range, depending on } \\
\text { geographic location); } \\
\text { values in meters. }\end{array}$ \\
\hline TRLVL & 65 & 72 & Real & $\begin{array}{l}\text { Data variable - the average } \\
\text { of the mean tide levels of } \\
\text { all the gauge stations that } \\
\text { occur within a given } 0.25^{\circ} \\
\text { grid cell (mean tide level } \\
\text { is a plane midway between } \\
\text { mean low water and mean } \\
\text { high water in 1992). } \\
\text { Values were reckoned } \\
\text { from the West Coast Mean } \\
\text { Low Water Datum. }\end{array}$ \\
\hline TRNUM & 73 & 76 & Integer & $\begin{array}{l}\text { Data variable - number of } \\
\text { tide gauge stations used in } \\
\text { calculating TRAVG, } \\
\text { TRMAX, and TRLVL for } \\
\text { a given } 0.25^{\circ} \text { grid cell. }\end{array}$ \\
\hline
\end{tabular}


Table 11. ' (concluded)

\begin{tabular}{|c|c|c|c|c|}
\hline \multicolumn{5}{|c|}{ Column } \\
\hline Variable name & Start & End & Variable type & Variable description \\
\hline TRR & 77 & 80 & Integer & $\begin{array}{l}\text { Data variable - classified } \\
\text { version of the mean tide } \\
\text { range variable (i.e., } \\
\text { TRAVG). }\end{array}$ \\
\hline WHAVG & 1 & 8 & Real & $\begin{array}{l}\text { Data variable - } 20 \text {-year } \\
\text { mean wave height } \\
\text { experienced within each } \\
0.25^{\circ} \text { grid cell; values in } \\
\text { meters. }\end{array}$ \\
\hline WHMAX & 9 & 16 & Real & $\begin{array}{l}\text { Data variable - maximum } \\
\text { significant wave height for } \\
\text { each } 0.25^{\circ} \text { grid cell; values } \\
\text { in meters. }\end{array}$ \\
\hline WHSD & 17 & 24 & Real & $\begin{array}{l}\text { Data variable - standard } \\
\text { deviation of the } 20 \text {-year } \\
\text { mean wave height } \\
\text { experienced within each } \\
0.25^{\circ} \text { grid cell; values in } \\
\text { meters. }\end{array}$ \\
\hline WHR & 25 & 28 & Integer & $\begin{array}{l}\text { Data variable - classified } \\
\text { version of the maximum } \\
\text { significant wave-height } \\
\text { variable (i.e., WHMAX). }\end{array}$ \\
\hline
\end{tabular}

Within WCLINE, missing data values are indicated as follows:

-9999.99- A line segment with real data values that is missing data for a given data variable.

9999- A line segment with integer data values that is missing data for a given data variable.

0- A line segment with missing data values for the risk variables (i.e., for variables ELR, ERR, WHR, TRR, LSR, GLR, GMR only). 
A value of 0.0 is a valid value for all but the risk variables. For the elevation variables $0.0 \mathrm{~m}$ indicates that land occurs within the given grid cell, but the maximum elevation of this land is < $1.0 \mathrm{~m}$. If the data variables in a given data set, such as elevation, contain data and the "number" variable is set to zero (i.e., ELNUM, ERNUM, TRNUM, or SLYR), then the data variables for the given $0.25^{\circ}$ grid cell have been estimated.

\section{Data Group WCPOINT:}

This data group contains the point data for the stations used in calculating the relative sea-level trend, long-term geologic-trend, corrected sea-level trend, local subsidence trend, mean tide range, maximum tide range, and mean tide level variables contained within data group WCGRD. Data include station names, station number, record length, latitude/longitude location, and data variable values.

The names of the Arc/Info ${ }^{\mathrm{TM}}$ coverage and flat ASCII file are WCPOINT.E00 (File 16 and WCPOINT.ASC (File 17), respectively. A summary of the format used for File 17 follows:

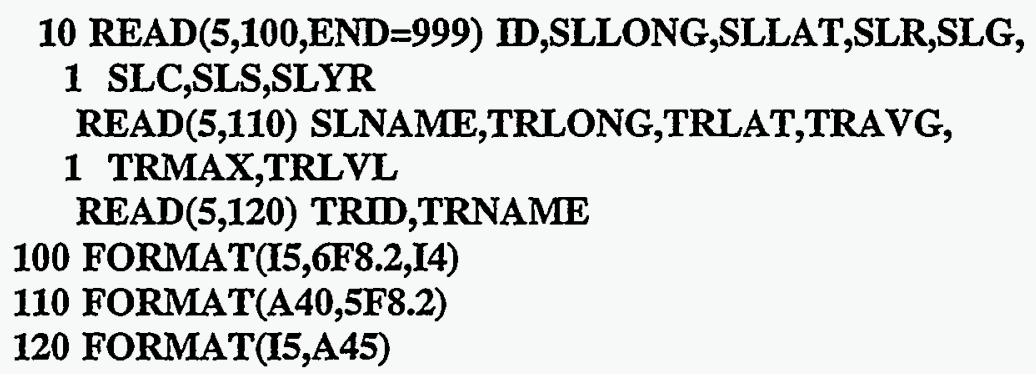

The variables listed in Table 12 are listed as they appear in data group WCPOINT (File 17).

Table 12. Variable formats for WCPOINT.ASC (File 17).

\begin{tabular}{|c|c|c|c|c|}
\hline \multirow[b]{2}{*}{ Variable name } & \multicolumn{2}{|c|}{ Column } & \multirow[b]{2}{*}{ Variable type } & \multirow[b]{2}{*}{ Variable description } \\
\hline & Start & End & & \\
\hline $\mathrm{ID}$ & 1 & 5 & Integer & $\begin{array}{l}\text { System variable - Point } \\
\text { identification number. }\end{array}$ \\
\hline SLLONG & 6 & 13 & Real & $\begin{array}{l}\text { Data variable - longitude } \\
\text { of the tide- gauge station } \\
\text { used in determining the } \\
\text { sea-level trends. }\end{array}$ \\
\hline SLLAT & 14 & 21 & Real & $\begin{array}{l}\text { Data variable - latitude of } \\
\text { the tide- gauge station } \\
\text { used in determining the } \\
\text { sea-level trends. }\end{array}$ \\
\hline
\end{tabular}


Table 12. (continued)

\begin{tabular}{|c|c|c|c|c|}
\hline \multirow[b]{2}{*}{ Variable name } & \multicolumn{2}{|c|}{ Column } & \multirow[b]{2}{*}{ Variable type } & \multirow[b]{2}{*}{ Variable description } \\
\hline & Start & End & & \\
\hline SLR & 22 & 29 & Real & $\begin{array}{l}\text { Data variable - relative } \\
\text { sea-level trend calculated } \\
\text { from tide-gauge station } \\
\text { measurements; values are } \\
\text { expressed in mm/year. }\end{array}$ \\
\hline SLG & 30 & 37 & Real & $\begin{array}{l}\text { Data variable - long-term } \\
\text { geologic trend. This } \\
\text { variable is } 0.0 \text { for all } \\
\text { stations with a relative sea- } \\
\text { level trend value, and is } \\
\text { included for compatibility } \\
\text { within this series of NDPs. }\end{array}$ \\
\hline SLC & 38 & 45 & Real & $\begin{array}{l}\text { Data variable - corrected } \\
\text { sea-level trend. Since the } \\
\text { geologic trend variable } \\
\text { contains values of } 0.0 \text {, this } \\
\text { variable appears identical } \\
\text { to the relative sea-level } \\
\text { trend variable; and is } \\
\text { included only for } \\
\text { compatibility within this } \\
\text { series of NDPs. }\end{array}$ \\
\hline SLS & 46 & 53 & Real & $\begin{array}{l}\text { Data variable - local uplift } \\
\text { or subsidence trend. } \\
\text { Relative sea-level trend } \\
\text { corrected for the global } \\
\text { eustatic rate of sea-level } \\
\text { rise (i.e., } 1.5 \mathrm{~mm} \text { /year). }\end{array}$ \\
\hline SLYR & 54 & 57 & Integer & $\begin{array}{l}\text { Data variable - years of } \\
\text { record of the tide gauge } \\
\text { station used in determining } \\
\text { the sea-level trends. }\end{array}$ \\
\hline
\end{tabular}


Table 12. (continued)

\begin{tabular}{|c|c|c|c|c|}
\hline \multicolumn{5}{|c|}{ Column } \\
\hline Variable name & Start & End & Variable type & Variable description \\
\hline
\end{tabular}

SLNAME

TRLONG

TRLAT

TRAVG

TRMAX

65

72

Real

TRLVL

1

41

49

57

64

Real

Real

Real

56

Char
Data variable - name of the tide gauge used for determining the sea-level trends.

Data variable - longitude of a tide-gauge station used for determining the tide range variables.

Data variable - latitude of a tide-gauge station used for determining the tide range variables.

Data variable - difference between mean high water and mean low water for 1992; values in meters.

Data variable - maximum tide range, maximum measured range for the gauge station in 1992 (this value may be the "spring" or "diurnal" tide range, depending on geographic location); values in meters.

Data variable - mean tide level, a plane midway between mean low water and mean high water in 1992. Values are reckoned from the West Coast Mean Low Water Datum. 
Table 12. (concluded)

\begin{tabular}{|c|c|c|c|c|}
\hline \multirow[b]{2}{*}{ Variable name } & \multicolumn{2}{|c|}{ Column } & \multirow[b]{2}{*}{ Variable type } & \multirow[b]{2}{*}{ Variable description } \\
\hline & Start & End & & \\
\hline TRID & 1 & 4 & Integer & $\begin{array}{l}\text { Data variable - station } \\
\text { number (used in the } 1992 \\
\text { Tide Tables) of a tide- } \\
\text { gauge station. }\end{array}$ \\
\hline TRNAME & 5 & 54 & Char & $\begin{array}{l}\text { Data variable - name of a } \\
\text { tide-gauge station (from } \\
\text { the } 1992 \text { Tide Tables). }\end{array}$ \\
\hline
\end{tabular}

Within this data file, WCPOINT, missing data values are indicated with one of the following values:

0.0 or 0 - A sea-level or tide-range station that has not been assigned data values. This data group includes the calculated relative sea-level trend measurements in $\mathrm{mm} / \mathrm{yr}$ for 16 tide-gauge stations (Woodworth 1995; Spencer and Woodworth 1993) and the tide table data for 410 NOAA stations (NOS 1992). The sea-level and tide-range stations each have unique data variables. When the 16 stations used for the calculated sea-level trend measurements are present, the tide range variables are 0.0 or 0 . When the 410 NOAA stations are present, the sea-level variables are 0.0 or 0 .

\section{Data Group WCOAST:}

The final data group, WCOAST (Files 20 and 21), contains a 1:2,000,000 digitized coastline of the U.S. West Coast made up of 1,262 line segments. Data in this coverage were extracted from a digitized map of the United States (originally compiled by the U.S. Geological Survey). This coastline may be overlaid onto any of the data groups previously discussed to provide locational information when plotting the data variables. The line segment identification numbers used herein are identical to the line segment identification numbers used in WCLINE.ASC. Unlike the other data groups within this data base this coverage contains no attribute values. However, such overlay commands as UNION, INTERSECT, and IDENTITY in Arc/Info ${ }^{\mathrm{TM}}$ (or other GISs) may be used to transfer the gridded data values to the coastal segments, thus simplifying the interpretation of any derived indices.

The name of the Arc/Info ${ }^{\mathrm{TM}}$ coverage where the coastline resides is WCOAST.E00 (File 20), and the flat ASCII data file with this same information is in WCOAST.ASC (File 21). Since this file is line based, the data values in WCOAST.ASC contain the line segment name, the number of points in the line, and a listing of the points that describe each line, for all 1,262 line segments that define the West Coast. 
The flat ASCII version of this file contains a listing of the line segments (or arcs) that describe the coast in the BNA format. An example of the format for this file is shown in Table 13.

Table 13. Sample of the vector format used for WCOAST.ASC (File 21).

$11 ",-6$
$-122.7500,48.9764$
$-122.7500,48.9796$
$-122.7524,48.9832$
$-122.7572,48.9852$
$-122.7600,48.9916$
$-122.7656,49.0000$
$" \quad 2 ",-11$
$-122.7984,48.9724$
$-122.7956,48.9760$
$-122.7944,48.9792$
$-122.7920,48.9820$
$-122.7896,48.9848$
$-122.7848,48.9856$
$-122.7824,48.9828$
$-122.7864,48.9808$
$-122.7896,48.9780$
$-122.7920,48.9752$
$-122.7916,48.9716$

...

\section{Listing of the FORTRAN Data Retrieval Programs}

This section lists the five FORTRAN data retrieval programs provided by CDIAC with this data base. Each program is designed to read and write the contents of one of the five flat ASCII data files.

The first program (WCGRID.FOR, File 2) is designed to read and print the file WCGRID.ASC (File 5).

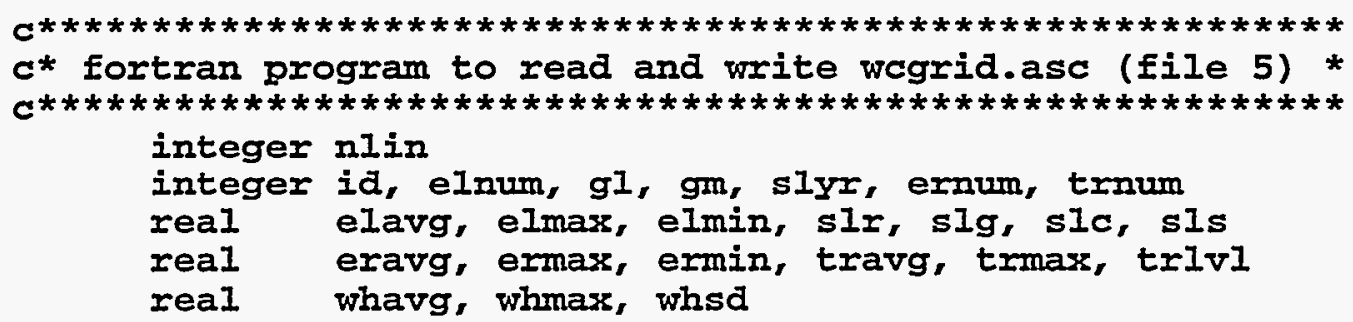




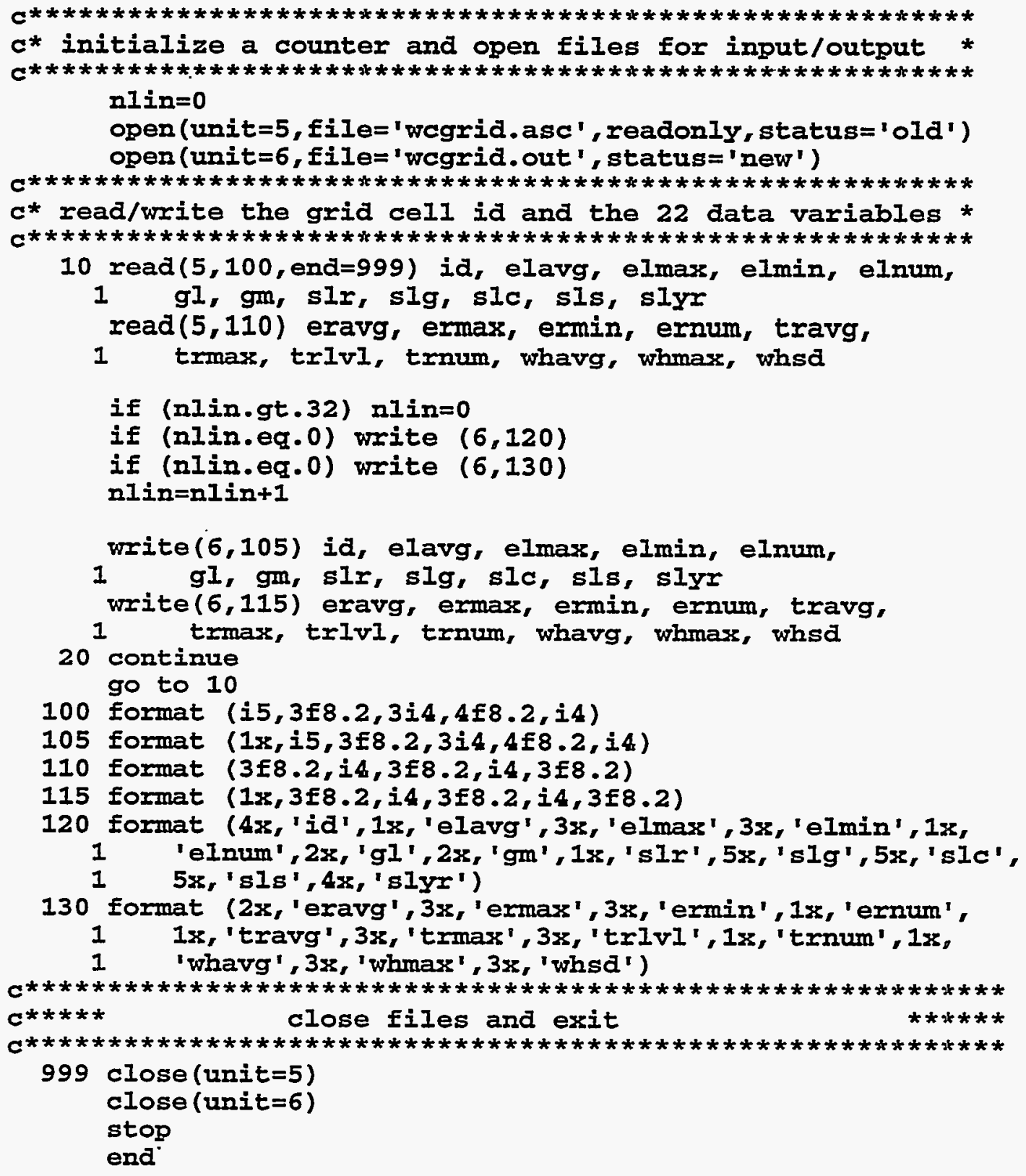

The second FORTRAN program (WCRISK.FOR, File 6) is designed to read and print the file WCRISK.ASC (File 9).

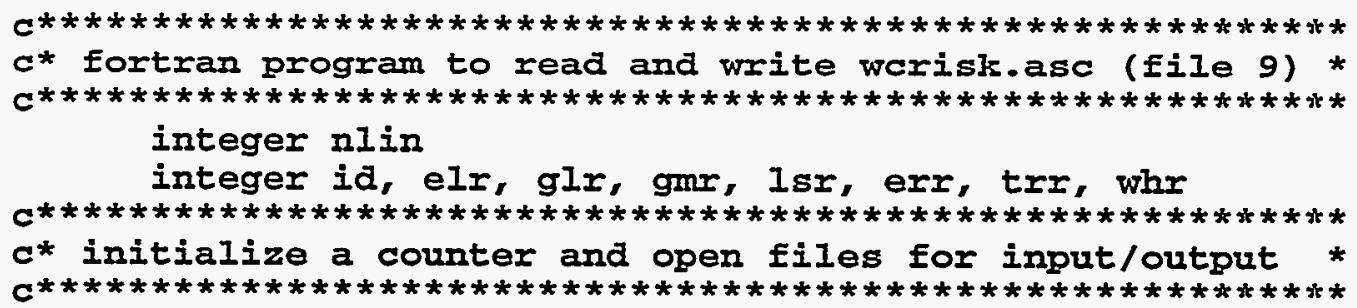




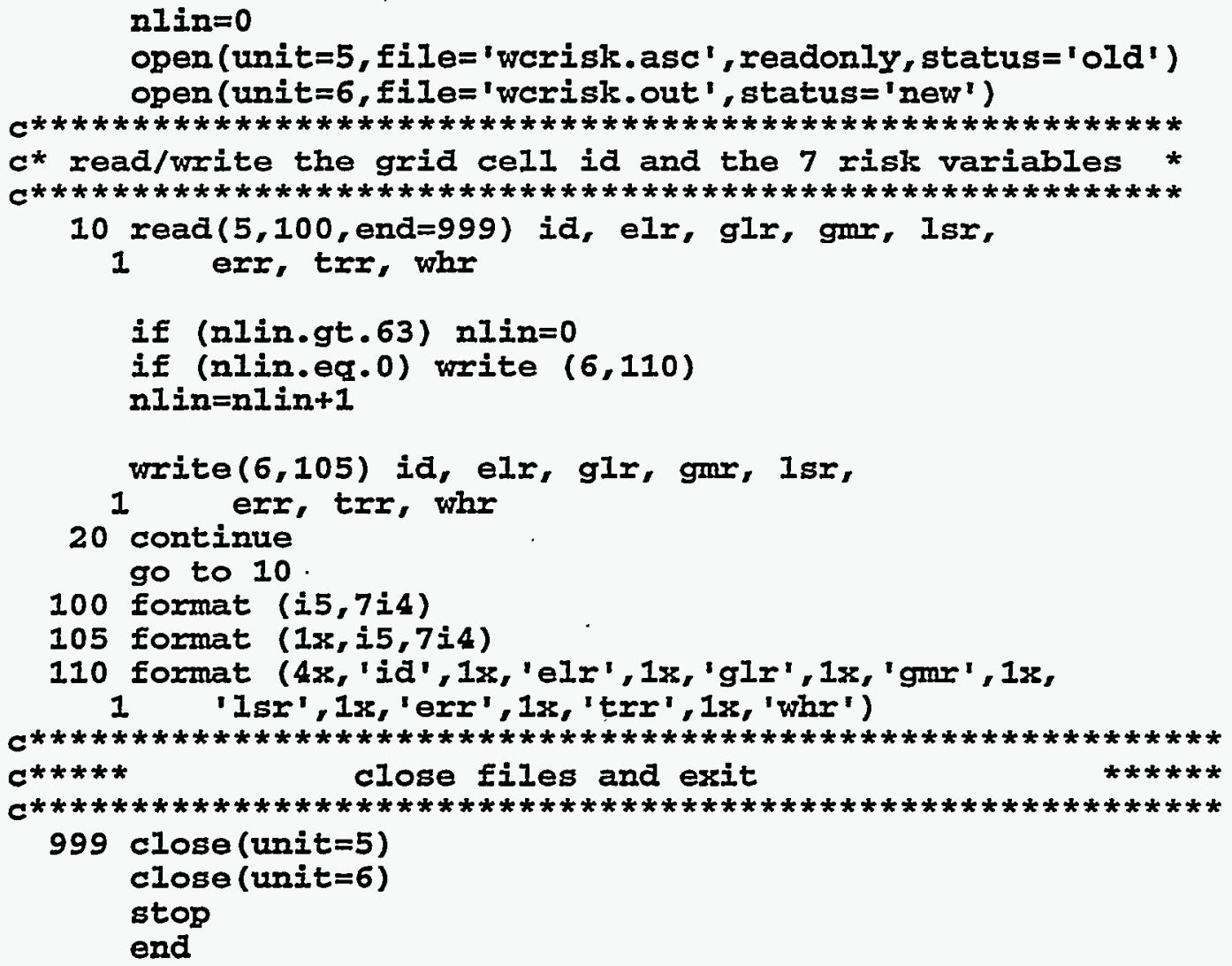

The third FORTRAN program (WCLINE.FOR, File 10) is designed to read and print the file WCLINE.ASC (File 13).

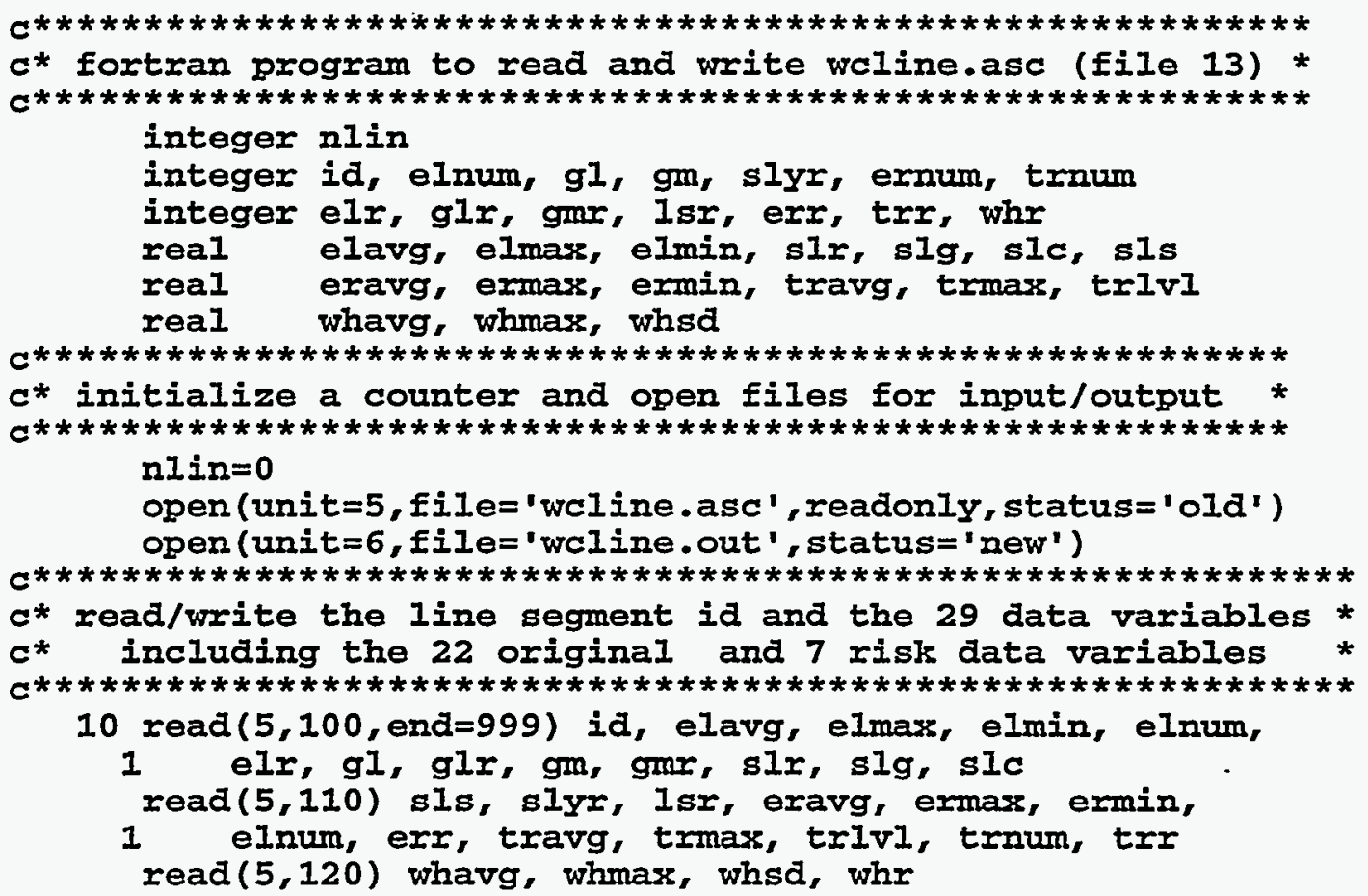




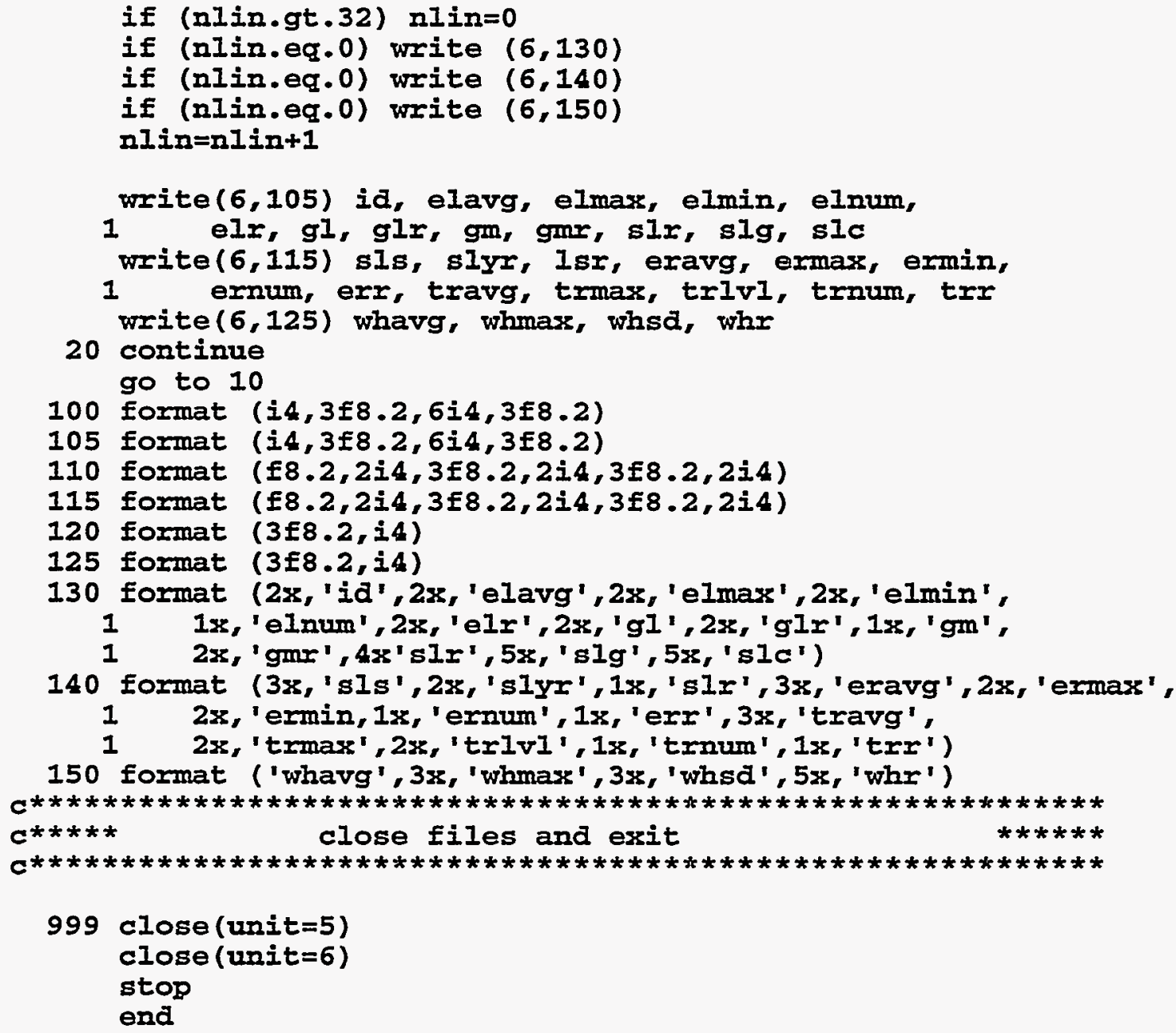

The fourth FORTRAN program (WCPOINT.FOR, file 14) is designed to read and print the file WCPOINT.ASC (File 17).

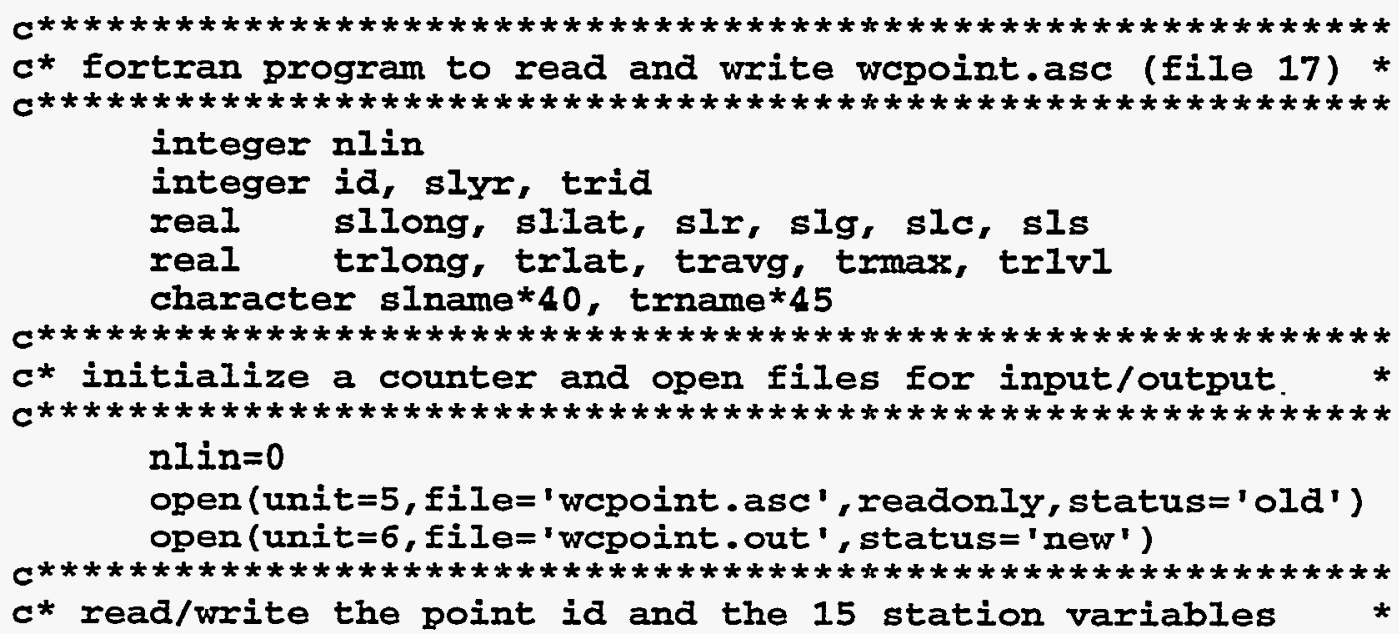




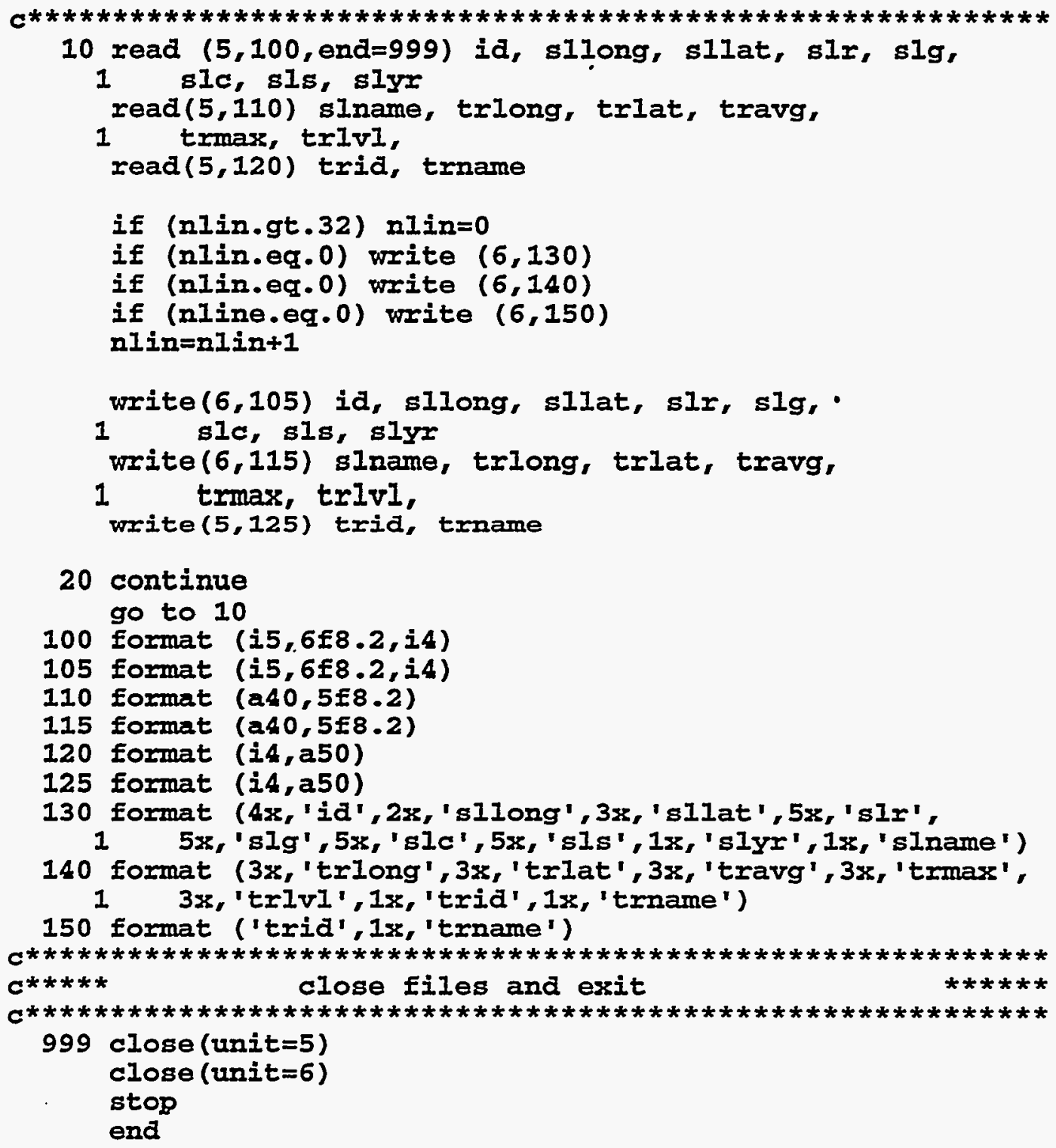

The last FORTRAN program (WCOAST.FOR, File 18) is designed to read and print the file WCOAST.ASC (File 21).

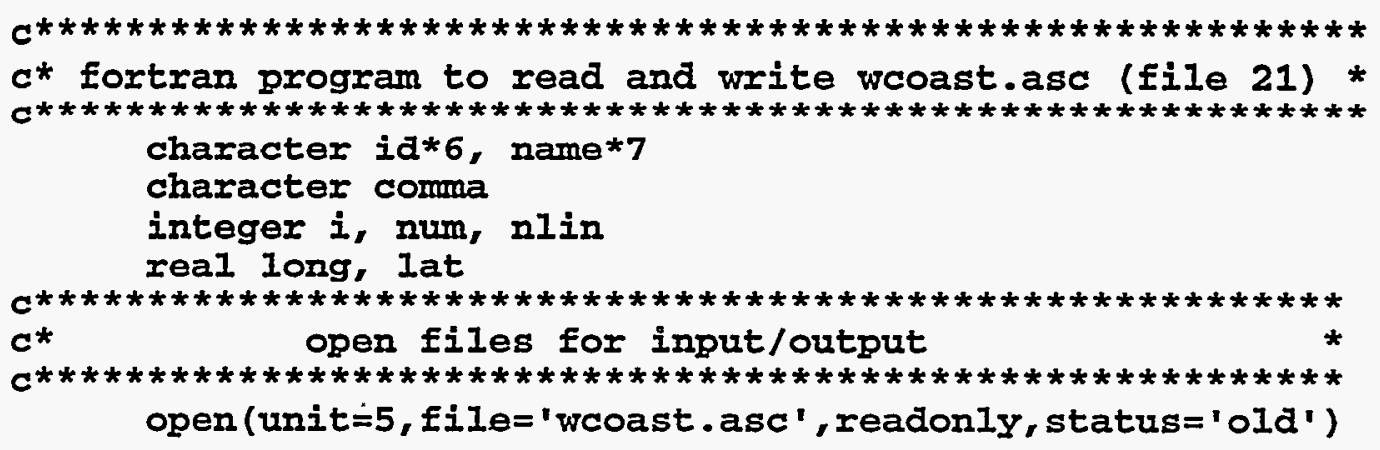




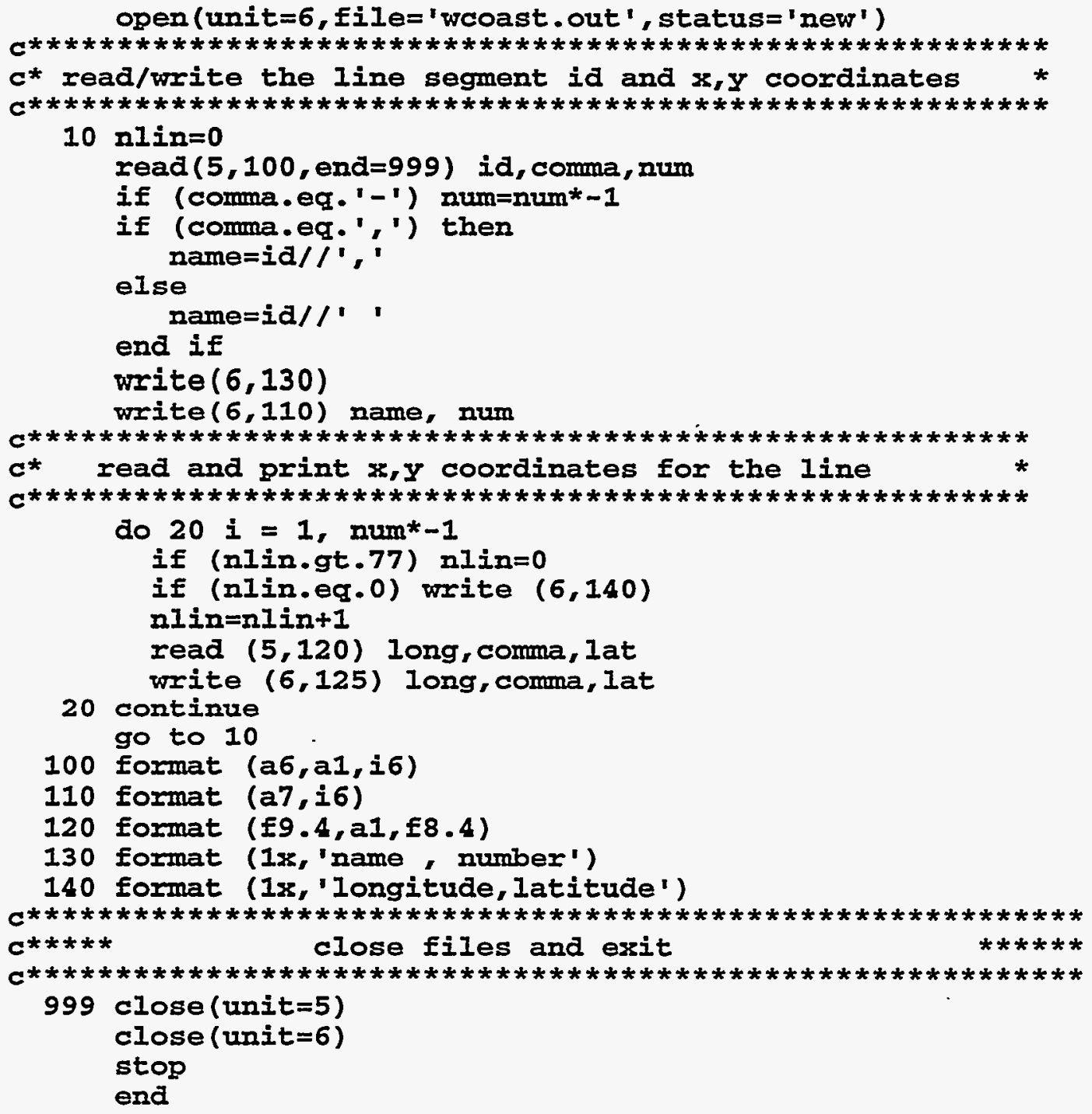

\section{Listing of the $S A S^{\mathrm{TM}}$ Data Retrieval Programs}

This section lists the five SAS ${ }^{\mathrm{TM}}$ data retrieval programs provided by CDIAC with this data base. Each program is designed to read and write the contents of one of the five flat ASCII data files. The first program (WCGRID.SAS, File 3) is designed to read and print the file WCGRID.ASC (File 5).

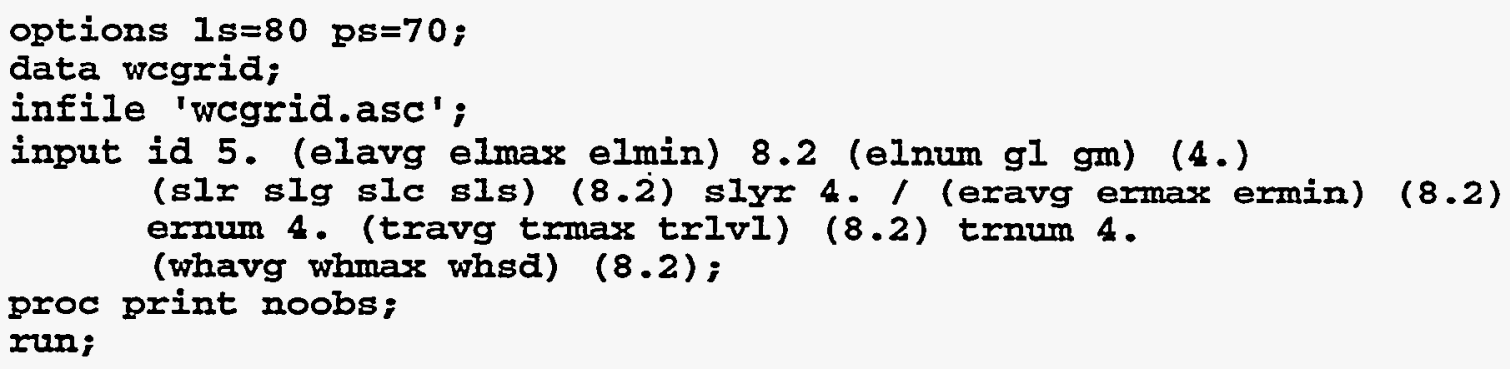


The second SAS ${ }^{\mathrm{TM}}$ program (WCRISK.SAS, File 7) is designed to read and print the file WCRISK.ASC (File 9).

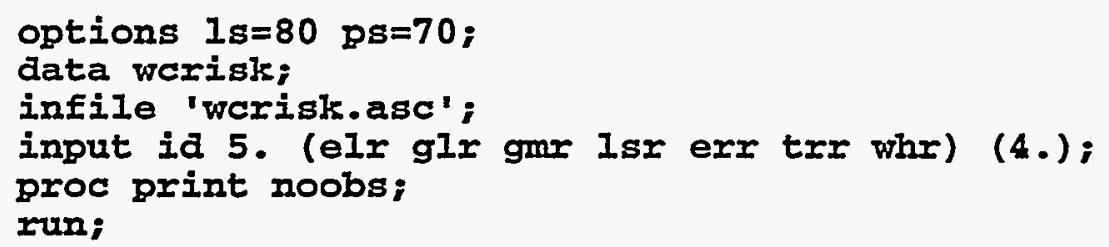

The third SAS ${ }^{\mathrm{TM}}$ program (WCLINE.SAS, File 11) is designed to read and print the file WCLINE.ASC (File 13).

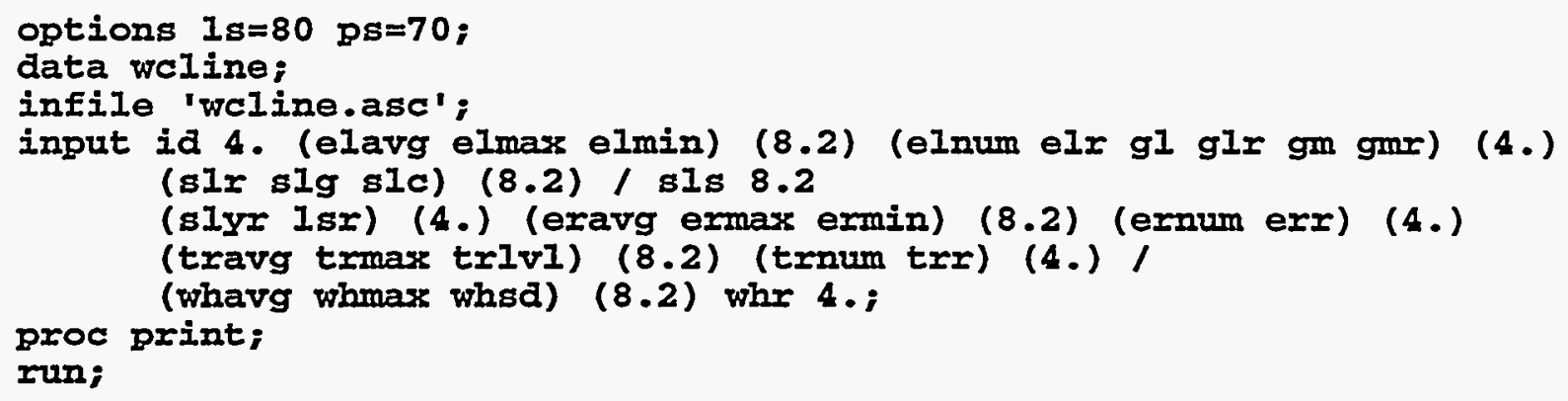

The fourth SAS ${ }^{\mathrm{TM}}$ program (WCPOINT.SAS, File 15) is designed to read and print the file WCPOINT.ASC (File 17).

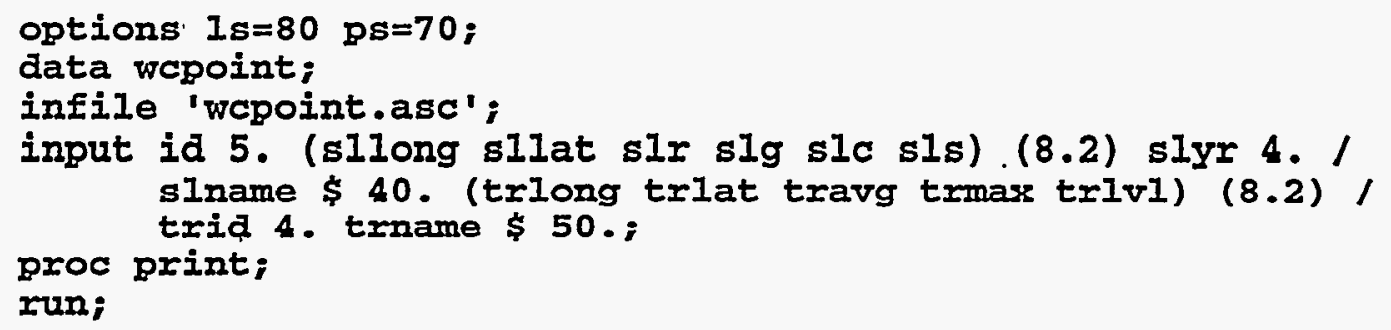


The fifth SAS ${ }^{\mathrm{TM}}$ program (File 19) is designed to read and print the file WCOAST.ASC (File 21).

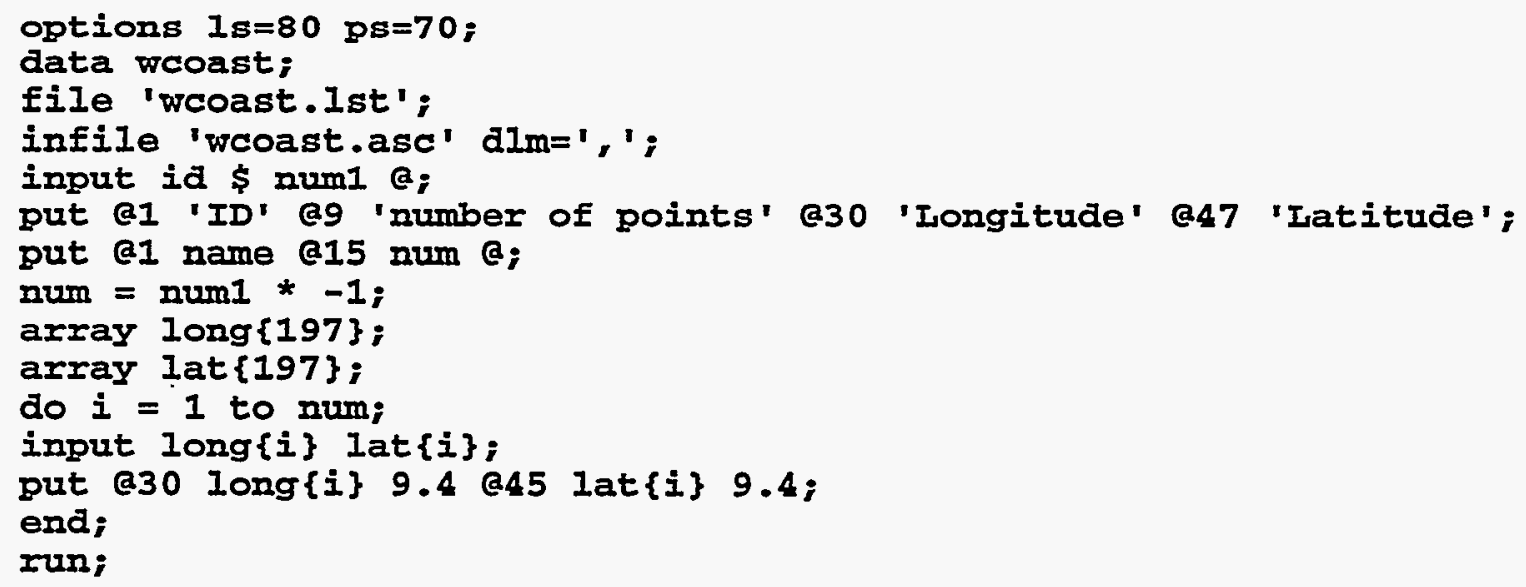

\section{Partial Listings of the Flat ASCII Data Files}

This section lists the first and last five data lines of each of the of the flat ASCI data files provided with this data base.

Sample listing of WCGRD.ASC (file 5).

\footnotetext{
1-9999.99-9999.99-9999.99999999999999-9999.99-9999.99-9999.99-9999.999999

-9999.99-9999.99-9999.999999-9999.99-9999.99-9999.999999-9999.99-9999.99-9999.99

2-9999.99-9999.99-9999.99999999999999-9999.99-9999.99-9999.99-9999.999999

-9999.99-9999.99-9999.999999-9999.99-9999.99-9999.999999-9999.99-9999.99-9999.99 3-9999.99-9999.99-9999.99999999999999-9999.99-9999.99-9999.99-9999.999999

-9999.99-9999.99-9999.999999-9999.99-9999.99-9999.999999-9999.99-9999.99-9999.99 4-9999.99-9999.99-9999.99999999999999-9999.99-9999.99-9999.99-9999.999999

-9999.99-9999.99-9999.999999-9999.99-9999.99-9999.999999-9999.99-9999.99-9999.99 5-9999.99-9999.99-9999.99999999999999-9999.99-9999.99-9999.99-9999.999999 -9999.99-9999.99-9999.999999-9999.99-9999.99-9999.999999-9999.99-9999.99-9999.99

2716-9999.99-9999.99-9999.99999999999999-9999.99-9999.99-9999.99-9999.999999

-9999.99-9999.99-9999.999999-9999.99-9999.99-9999.999999-9999.99-9999.99-9999.99

2717-9999.99-9999.99-9999.99999999999999-9999.99-9999.99-9999.99-9999.999999

-9999.99-9999.99-9999.999999-9999.99-9999.99-9999.999999-9999.99-9999.99-9999.99

2718-9999.99-9999.99-9999.99999999999999-9999.99-9999.99-9999.99-9999.999999

-9999.99-9999.99-9999.999999-9999.99-9999.99-9999.999999-9999.99-9999.99-9999.99

2719-9999.99-9999.99-9999.99999999999999-9999.99-9999.99-9999.99-9999.999999

-9999.99-9999.99-9999.999999-9999.99-9999.99-9999.999999-9999.99-9999.99-9999.99

2720-9999.99-9999.99-9999.99999999999999-9999.99-9999.99-9999.99-9999.999999

-9999.99-9999.99-9999.999999-9999.99-9999.99-9999.999999-9999.99-9999.99-9999.99
} 
Sample listing of WCRISK.ASC (File 9).

\begin{tabular}{rlllllll}
\hline 1 & 0 & 0 & 0 & 0 & 0 & 0 & 0 \\
2 & 0 & 0 & 0 & 0 & 0 & 0 & 0 \\
3 & 0 & 0 & 0 & 0 & 0 & 0 & 0 \\
4 & 0 & 0 & 0 & 0 & 0 & 0 & 0 \\
5 & 0 & 0 & 0 & 0 & 0 & 0 & 0 \\
6 & 0 & 0 & 0 & 0 & 0 & 0 & 0 \\
7 & 0 & 0 & 0 & 0 & 0 & 0 & 0 \\
8 & 0 & 0 & 0 & 0 & 0 & 0 & 0 \\
9 & 0 & 0 & 0 & 0 & 0 & 0 & 0 \\
10 & 0 & 0 & 0 & 0 & 0 & 0 & 0 \\
2711 & 0 & 0 & 0 & 0 & 0 & 0 & 0 \\
2712 & 0 & 0 & 0 & 0 & 0 & 0 & 0 \\
2713 & 0 & 0 & 0 & 0 & 0 & 0 & 0 \\
2714 & 0 & 0 & 0 & 0 & 0 & 0 & 0 \\
2715 & 0 & 0 & 0 & 0 & 0 & 0 & 0 \\
2716 & 0 & 0 & 0 & 0 & 0 & 0 & 0 \\
2717 & 0 & 0 & 0 & 0 & 0 & 0 & 0 \\
2718 & 0 & 0 & 0 & 0 & 0 & 0 & 0 \\
2719 & 0 & 0 & 0 & 0 & 0 & 0 & 0 \\
2720 & 0 & 0 & 0 & 0 & 0 & 0 & 0 \\
& & & & & & &
\end{tabular}

Sample listing of WCLINE.ASC (File 13).

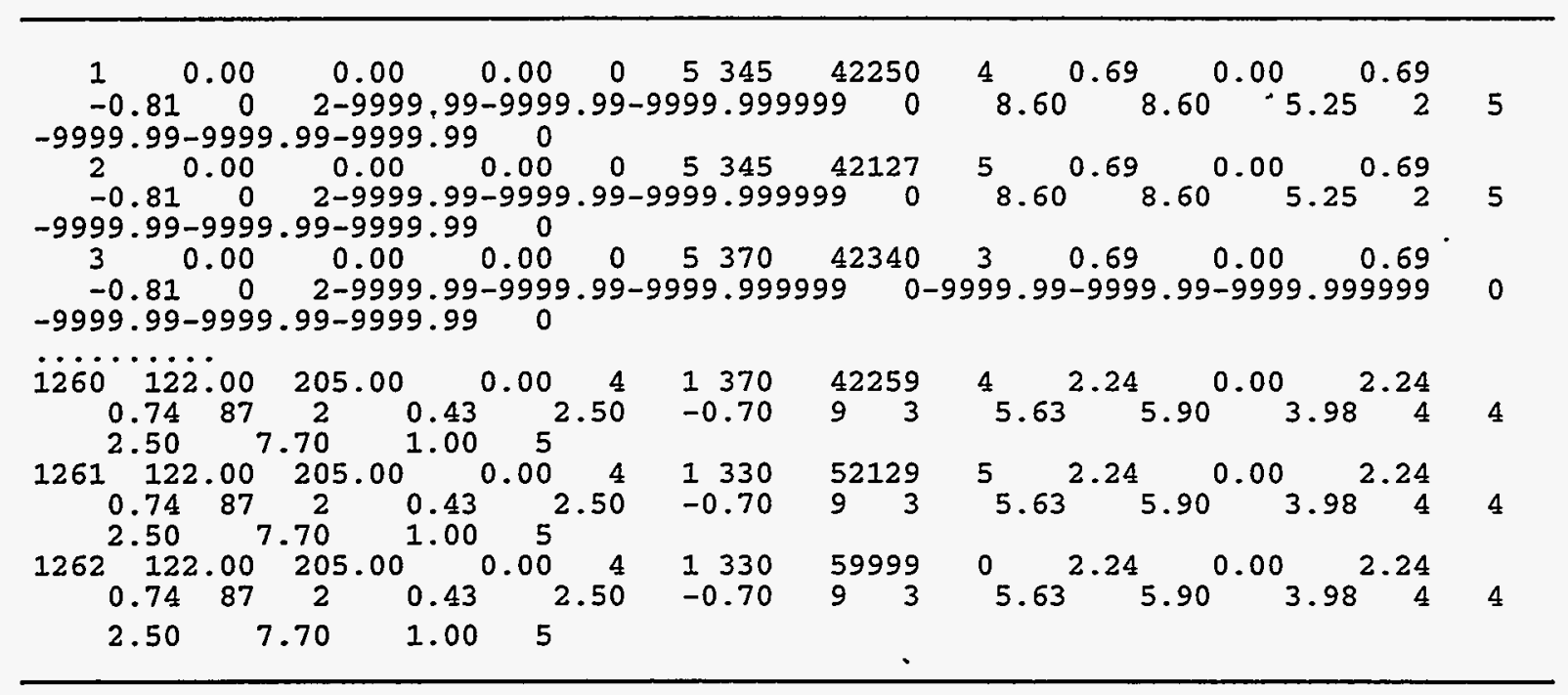


Sample listing of WCPOINT.ASC (file 17).

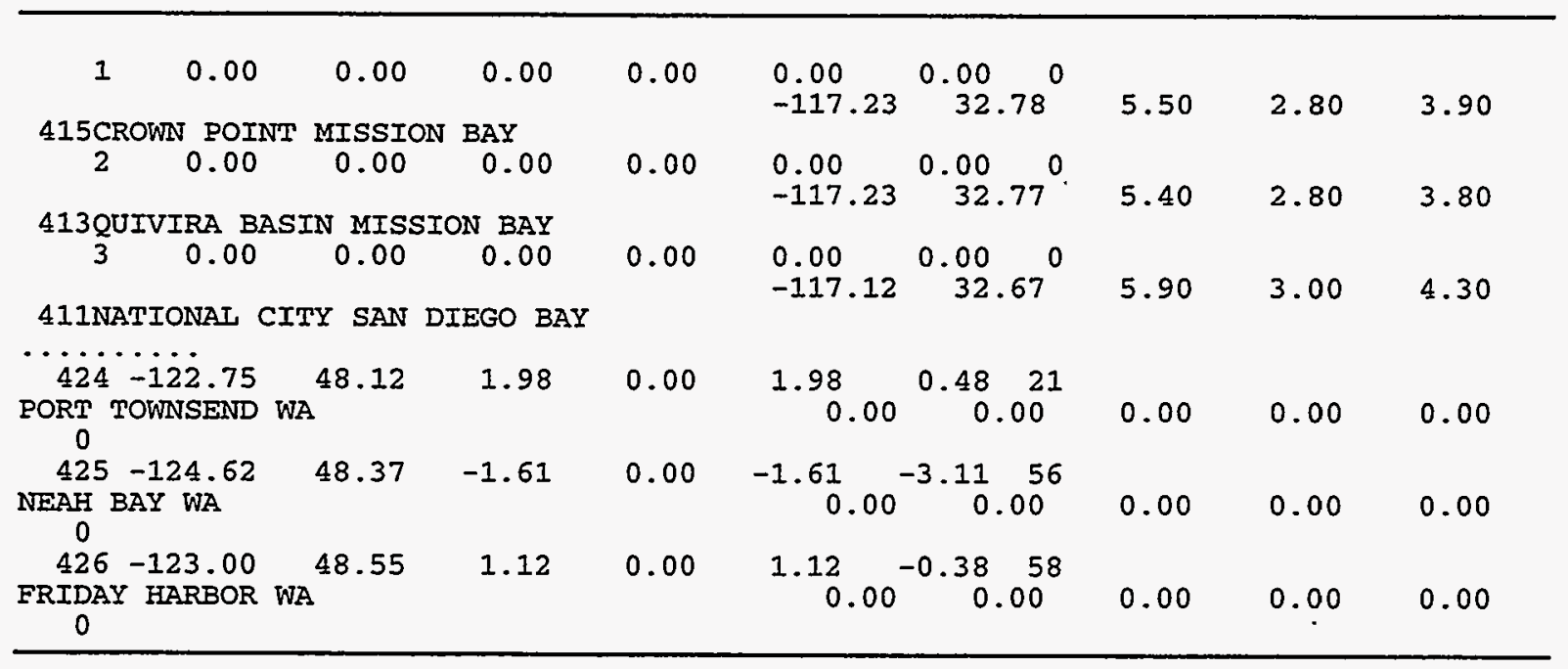

Sample listing of WCOAST.ASC (file 21).

$$
\begin{aligned}
& \text { "1", }-6 \\
& -122.7500,48.9764 \\
& -122.7500,48.9796 \\
& -122.7524,48.9832 \\
& -122.7572,48.9852 \\
& -122.7600,48.9916 \\
& -122.7656,49.0000 \\
& " 1 *-11 \\
& -122.7984,48.9724 \\
& -122.7956,48.9760 \\
& -122.7944,48.9792 \\
& -122.7920,48.9820 \\
& -122.7896,48.9848 \\
& -122.7848,48.9856 \\
& -122.7824,48.9828 \\
& -122.7864,48.9808 \\
& -122.7896,48.9780 \\
& -122.7920,48.9752 \\
& -122.7916,48.9716 \\
& -1197 \% \\
& -1262 \%-4 \\
& -117.1372,32.5800 \\
& -117.1372,32.5784 \\
& -117.1368,32.5716 \\
& -117.1332,32.5612
\end{aligned}
$$




\section{Verification of Data Transport: Flat ASCII Data Files.}

The gridded coastal hazards data base and the original point data may be read using the FORTRAN or SAS ${ }^{\mathrm{TM}}$ input/output routines provided. After these files are loaded onto the system it should be verified that the files have not been corrupted during transport. To do this, some or all of the statistics or characteristics presented in the following tables should be generated. These statistics were obtained for WCGRID, WCRISK, WCLINE, WCPOINT, and WCOAST using the SAS ${ }^{\mathrm{TM}}$ statistical package (i.e., with PROC MEANS); however, these statistics may be duplicated using other statistical packages or computer languages.

These statistics are presented only as a tool to ensure proper reading of the four flat ASCII data files and should not be construed as either a summary of the data or as an indicator of trends in the data.

Table 14. Statistical characteristics of the numeric variables in WCGRID.ASC (File 5).

\begin{tabular}{lrrrrr}
\hline & & & & & \\
Variable & $N$ & \multicolumn{1}{l}{ Mean } & Std. dev. & Minimum & Maximum \\
\hline & & & & & \\
D & 2720 & 1360.50 & 785.34 & 1.00 & 2720.00 \\
ELAVG & 2720 & -9197.86 & 2738.93 & -9999.99 & 885.00 \\
ELMAX & 2720 & -9193.41 & 2754.40 & -9999.99 & 920.00 \\
ELMIN & 2720 & -9202.52 & 2722.85 & -9999.99 & 850.00 \\
ELNUM & 2720 & 9208.89 & 1.21 & 0.00 & 9999.00 \\
GL & 2720 & 9324.84 & 2467.59 & 110.00 & 9999.00 \\
GM & 2720 & 9401.81 & 2188.90 & 1110.00 & 9999.00 \\
SLR & 2720 & -9308.74 & 2441.09 & -9999.99 & 4.39 \\
SLG & 2720 & -9308.81 & 2440.89 & -9999.99 & 0.00 \\
SLC & 2720 & -9308.74 & 2441.09 & -9999.99 & 4.39 \\
SLS & 2720 & -9308.84 & 2440.72 & -9999.99 & 2.89 \\
SLYR & 2720 & -9308.23 & 3.82 & 0.00 & 9999.00 \\
ERAVG & 2720 & -9628.67 & 1891.19 & -9999.99 & 5.46 \\
ERMAX & 2720 & -9628.65 & 1891.27 & -9999.99 & 10.00 \\
ERMMN & 2720 & -9628.68 & 1891.12 & -9999.99 & 3.70 \\
ERNUM & 2720 & 9628.05 & 2.22 & 0.00 & 9999.00 \\
TRAVG & 2720 & -9440.77 & 2298.98 & -9999.99 & 14.60 \\
TRMAX & 2720 & -9440.76 & 2299.03 & -9999.99 & 15.00 \\
TRLVL & 2720 & -9462.96 & 2255.31 & -9999.99 & 10.80 \\
TRNUM & 2720 & 9440.38 & 0.94 & 0.00 & 9999.00 \\
WHAVG & 2720 & -9521.94 & 2134.18 & -9999.99 & 2.80 \\
WHMAX & 2720 & -9521.71 & 2135.23 & -9999.99 & 8.10 \\
WHSD & 2720 & -9522.00 & 2133.91 & -9999.99 & 1.30 \\
\hline & & & & & \\
\hline
\end{tabular}


Table 15. Statistical characteristics of the numeric variables in WCRISK.ASC (File 9).

\begin{tabular}{lrrrrr}
\hline Variable & $N$ & Mean & Std. dev. & Minimum & Maximum \\
\hline & & & & & \\
D & 2720 & 1360.50 & 785.34 & 1.00 & 2720.00 \\
ELR & 2720 & 0.19 & 0.83 & 0.00 & 5.00 \\
GLR & 2720 & 0.24 & 0.93 & 0.00 & 5.00 \\
GMR & 2720 & 0.20 & 0.81 & 0.00 & 5.00 \\
LSR & 2720 & 0.19 & 0.75 & 0.00 & 5.00 \\
ERR & 2720 & 0.11 & 0.56 & 0.00 & 5.00 \\
TRR & 2720 & 0.25 & 1.05 & 0.00 & 5.00 \\
WHR & 2720 & 0.22 & 1.01 & 0.00 & 5.00 \\
\hline
\end{tabular}

Table 16. Statistical characteristics of the numeric variables in WCLINE.ASC (File 13).

\begin{tabular}{lrrrrr}
\hline Variable & \multicolumn{1}{l}{ N } & \multicolumn{1}{l}{ Mean } & Std. dev. & Minimum & Maximum \\
\hline ID & 1262 & 631.50 & 364.45 & 1.00 & 1262.00 \\
ELAVG & 1262 & 150.21 & 174.59 & 0.00 & 885.00 \\
ELMAX & 1262 & 204.71 & 214.32 & 0.00 & 920.00 \\
ELMIN & 1262 & 93.52 & 140.47 & 0.00 & 850.00 \\
ELNUM & 1262 & 4405.33 & 4957.99 & 1.00 & 9999.00 \\
ELR & 1262 & 2.13 & 1.75 & 1.00 & 5.00 \\
GL & 1262 & 398.19 & 1020.53 & 110.00 & 9999.00 \\
GLR & 1262 & 3.36 & 1.23 & 0.00 & 5.00 \\
GM & 1262 & 1506.37 & 916.87 & 1110.00 & 9999.00 \\
GMR & 1262 & 2.93 & 1.38 & 0.00 & 5.00 \\
SLR & 1262 & -38.38 & 628.52 & -9999.99 & 4.29 \\
SLG & 1262 & -39.62 & 628.44 & -9999.99 & 0.00 \\
SLC & 1262 & -38.38 & 628,52 & -9999.99 & 4.39 \\
SLS & 1262 & -39.87 & 628.43 & -9999.99 & 2.89 \\
SLYR & 1262 & 47.01 & 628.27 & 0.00 & 9999.00 \\
LSR & 1262 & 1.90 & 0.62 & 0.00 & 4.00 \\
ERAVG & 1262 & -4397.81 & 4965.53 & -9999.99 & 5.46 \\
ERMAX & 1262 & -4397.58 & 4965.73 & -9999.99 & 10.00 \\
ERMIN & 1262 & -4398.04 & 4965.33 & -9999.99 & 3.70 \\
ERNUM & 1262 & 4405.33 & 4957.99 & 1.00 & 9999.00 \\
ERR & 1262 & 1.61 & 1.48 & 0.00 & 5.00 \\
& & & & &
\end{tabular}


Table 16. (concluded)

\begin{tabular}{lrrrrr}
\hline Variable & \multicolumn{1}{l}{ N } & \multicolumn{1}{l}{ Mean } & Std. dev. & Minimum & Maximum \\
\hline & & & & & $\cdot$ \\
TRAVG & 1262 & -2054.45 & 4049.01 & -9999.99 & 14.60 \\
TRMAX & 1262 & -2054.25 & 4049.11 & -9999.99 & 15.00 \\
TRLVL & 1262 & -2056.19 & 4048.12 & -9999.99 & 10.80 \\
TRNUM & 1262 & 2062.74 & 4044.28 & 1.00 & 9999.00 \\
TRR & 1262 & 3.66 & 1.92 & 0.00 & 5.00 \\
WHAVG & 1262 & -2985.69 & 4579.90 & -9999.99 & 2.80 \\
WHMAX & 1262 & -2982.29 & 4582.11 & -9999.99 & 8.10 \\
WHSD & 1262 & -2986.58 & 4579.31 & -9999.99 & 1.30 \\
WHR & 1262 & 3.32 & 2.21 & 0.00 & 5.00 \\
& & & & & \\
\hline
\end{tabular}

Table 17. Statistical characteristics of the numeric variables in WCPOINT.ASC (File 17).

\begin{tabular}{|c|c|c|c|c|c|}
\hline Variable & $N$ & Mean & Std. dev. & Minimum & Maximum \\
\hline ID & 426 & 213.50 & 123.12 & 1.00 & 426.00 \\
\hline SLLONG & 426 & -4.58 & 23.10 & -124.62 & 0.00 \\
\hline SLLAT & 426 & 1.50 & 7.70 & 0.00 & 48.55 \\
\hline SLR & 426 & 0.05 & 0.38 & -1.61 & 4.39 \\
\hline SLG & 426 & 0.00 & 0.00 & 0.00 & 0.00 \\
\hline SLC & 426 & 0.05 & 0.38 & -1.61 & 4.39 \\
\hline SLS & 426 & -0.01 & 0.28 & -3.11 & 2.89 \\
\hline SLYR & 426 & -2.23 & 12.69 & 0.00 & 140.00 \\
\hline TRLONG & 426 & -117.87 & $23.36^{\circ}$ & -125.13 & 0.00 \\
\hline TRLAT & 426 & 40.62 & 9.51 & 0.00 & 49.00 \\
\hline TRAVG & 426 & -86.84 & 966.27 & -9999.99 & 15.00 \\
\hline TRMAX & 426 & -465.57 & 2118.64 & -9999.99 & 8.60 \\
\hline TRLVL & 426 & -300.27 & 1722.93 & -9999.99 & 11.00 \\
\hline TRD & 426 & 783.81 & 280.03 & 0.00 & 1277.00 \\
\hline
\end{tabular}


Table 18. Characteristics and size, in bytes and 512-byte blocks, of WCOAST.ASC (File 21).

\begin{tabular}{lll}
\hline $\begin{array}{l}\text { Number of } \\
\text { lines/arcs }\end{array}$ & $\begin{array}{l}\text { Size in } \\
\text { bytes }\end{array}$ & $\begin{array}{l}\text { Size in } \\
\text { blocks }\end{array}$ \\
\hline 1262 & 310,752 & 607 \\
\hline
\end{tabular}

\section{Verification of Data Transport: Arc/Info ${ }^{\mathrm{TM}}$ Export Files}

The five Arc/Info ${ }^{\mathrm{TM}}$ export files were created in Arc//nfo ${ }^{\mathrm{TM}}$, Version 7.0.3, using the EXPORT command with the COVER and NONE options. Each export file contains an entire coverage and its associated INFO data files in a fixed-length, uncompressed format.

The exported coverages are in a GEOGRAPHIC projection, which is a spherical reference system that locates positions using latitude and longitude coordinates that are stored in decimal degrees. As a result of this, the reference grids in which the data are stored are not uniform in size or area.

After loading the Arc/Info ${ }^{\mathrm{TM}}$ export files onto a system, the user should verify that the files have been correctly transported. To verify the integrity of the files, the size of the export files and (after importing the data into Arc/Info ${ }^{\mathrm{TM}}$ ) the total number of INFO data records in each coverage should be compared with those presented in Table 18. If the file sizes differ from those presented by $>1$ byte or the number of INFO data records do not match those shown in Table 18, then the coverage may have been corrupted in transport. The Arc/Info ${ }^{\mathrm{TM}}$.EO0 files may be imported into the user's $\mathrm{Arc} / \mathrm{Info}^{\mathrm{TM}}$ system using the IMPORT command with the COVER option. The IMPORT command will automatically recognize that the export file is in an uncompressed format (files should be EXTERNALIZED after being imported [e.g., ARC> external WCGRID]).

Table 19. File size and number of attribute records in each $\operatorname{Arc/Info}{ }^{\mathrm{TM}}$ export file.

\begin{tabular}{lcclc}
\hline $\begin{array}{l}\text { Export file } \\
\text { name }\end{array}$ & $\begin{array}{l}\text { Tape file } \\
\text { number }\end{array}$ & $\begin{array}{l}\text { File size } \\
\text { (bytes) }\end{array}$ & $\begin{array}{l}\text { Arc//nfo }^{\mathrm{TM}} \\
\text { coverage type }\end{array}$ & $\begin{array}{l}\text { Number of } \\
\text { records }\end{array}$ \\
\hline WCGRID.E00 & 4 & $2,923,400$ & Polygon & 2,721 \\
WCRISK.E00 & 8 & $1,874,584$ & Polygon & 2,721 \\
WCLINE.E00 & 12 & $1,211,476$ & Arc/Line & 1,262 \\
WCPOINT.E00 & 16 & 214,242 & Point & 426 \\
WCOAST.E00 & 20 & 651,721 & Arc/Line & 1,262 \\
\hline
\end{tabular}




\section{APPENDICES}


APPENDIX A: THE DATA GROUPS, A QUICK REFERENCE

A -1 


\section{THE DATA GROUPS: A QUICK REFERENCE}

The following provides a listing and description of the data variables and other pertinent information for each of the five data groups. The Arc/Info ${ }^{\mathrm{TM}}$ version of these files, contain several additional variables. These additional variables are system variables. For data groups WCGRID and WCRISK, the system variables AREA, PERIMETER, COVERNAME\# [i.e., cover name pound sign, an internal polygon, point, or line identification number (e.g., WCGRID\#, WCPOINT\#, and WCLINE\# respectively)], and COVERNAME-ID [i.e., cover name dash identification number, an external polygon, point, or line identification number (e.g. WCGRID-ID, WCPOINT-ID, and WCLINE-id respectively)]. The external identification number is present in both the export (.EOO) and ASCI (.ASC) files and is used to identify the $0.25^{\circ}$ by $0.25^{\circ}$ grid cell, point, or 1:2,000,000 digitized line segment to which the data record belongs.

(1) Data Group WCGRD: Gridded polygon data for 22 data variables from the following data sets: elevation, geology, geomorphology, sea-level trend, shoreline displacement(erosion/accretion), tidal range, and wave heights. (A value of -9999.99 or 9999 indicates no data are available for the given data cell for a given data variable.)

Data Format - Arc/Info ${ }^{\mathrm{TM}}$ coverage and flat ASCII file with data values for each $0.25^{\circ}$ latitude by $0.25^{\circ}$ longitude grid cell on the U.S. West Coast.

File Storage - Arc/Info ${ }^{T M}$ coverage name is WCGRID.EOO (File 4) ASCII file name is WCGRID.ASC (File 5).

\section{Data Variables}

ELAVG - Average elevation calculated from all positive $5^{\prime}$ by $5^{\prime}$ grid cells within a given $0.25^{\circ}$ grid cell; values expressed in meters.

ELMAX - Maximum elevation of all the positive $5^{\prime}$ by $5^{\prime}$ grid cells for a given $0.25^{\circ}$ grid cell; values expressed in meters.

ELMIN - Minimum elevation of all the positive $5^{\prime}$ by $5^{\prime}$ grid cells for a given $0.25^{\circ}$ grid cell, values expressed in meters.

ELNUM - Number of $5^{\prime}$ by $5^{\prime}$ grid cells used in calculating ELAVG, ELMmN, and ELMAX for a given $0.25^{\circ}$ grid cell.

GL - Ordinal value indicating the type and resistance of the rocks within a given $0.25^{\circ}$ grid cell to erosion through physical and chemical weathering.

GM - Ordinal value indicating the type and susceptibility of the landforms within a given $0.25^{\circ}$ grid cell to inundation and erosion.

SLR - Relative sea-level trend within a given $0.25^{\circ}$ grid cell; values are expressed in $\mathrm{mm} /$ year. Data values are based on the point data in data group WCPOINT. 
SLG - Geologic trend variable. In this data base this variable is 0.0 for all $0.25^{\circ}$ grid cells with a relative sea-level trend value, and -9999.99 for all grid cells without a relative sealevel trend value. This data variable has been included to ensure compatibility between the data bases in this series of NDPs (i.e., NDP-043A, NDP-043B, and NDP-043C). See Appendix $\mathrm{D}$ for additional geologic trends based on-long-term geologic data from raised marine terraces and ${ }^{14} \mathrm{C}$ data.

SLC - Corrected sea-level trend. Since the geologic trend variable contains values of 0.0 , this variable appears identical to the relative sea-level trend variable; and is included for compatibility within this series of NDPs. Some long-term geologic trends are listed in Appendix D.

SLS - Local subsidence trend derived from tide-gauge data and corrected for the global eustatic sea-level trend (i.e., 1.50); values are expressed in mm/year. Data values are based on the point data in data group WCPOINT.

SLYR - Number of years of record used in estimating the sea-level trend for each $0.25^{\circ}$ grid cell (grid cells in which tide-gauge stations do not occur have been assigned a zero value.) Data values are based on the point data in data group WCPOINT.

ERAVG - Average of the mean long-term erosion trend values for a given $0.25^{\circ}$ grid cell; values expressed in meters.

ERMAX - Maximum of the mean long-term erosion trends for a given $0.25^{\circ}$ grid cell; values expressed in meters.

ERMIN - Minimum of the mean long-term erosion trends for a given $0.25^{\circ}$ grid cell; values expressed in meters.

ERNUM - Number of $3^{\prime}, 7.5^{\prime}$, or $15^{\prime}$ grid cells (i.e., format of original data source) used in calculating ERAVG, ERMIN, or ERMAX for a given $0.25^{\circ}$ grid cell.

TRAVG - Average of the mean-tide-range values for all tide stations occurring within a given $0.25^{\circ}$ grid cell in 1992 (the mean tide range is the difference in height between mean high water and mean low water for 1992). Data values are expressed in meters and are based on the point data in data group WCPOINT.

TRMAX - Maximum tide range measured for all gauge stations that occurred within a given $0.25^{\circ}$ grid cell in 1992 (this value may be the "spring" or "diurnal" tide range, depending on geographic location). Data values are expressed in meters and are based on the point data in data group WCPOINT.

TRLVL - Average of the mean-tide-level values for all tide stations occurring within a given $0.25^{\circ}$ grid cell in 1992 (the mean tide level is a plane midway between mean low water and mean high water in 1992). Values are reckoned from chart datum, are expressed in meters, and are based on the point data in data group WCPOINT. 
TRNUM - Number of tide-gauge stations used in calculating TRAVG, TRMAX, and TRLVL for a given $0.25^{\circ}$ grid cell. Data values are based on the point data in data group WCPOINT.

WHAVG - 20-year mean wave height calculated for each $0.25^{\circ}$ grid cell: values expressed in meters.

WHMAX - Maximum significant wave height for each $0.25^{\circ}$ grid cell; values expressed in meters.

WHSD - Standard deviation of the mean wave heights experienced within each $0.25^{\circ}$ grid cell; values expressed in meters.

(2) Data Group WCRISK: Gridded polygon data for the seven classified risk . variables. The risk variables contain values ranging from 0 to 5 . A value of zero indicates no data are available for a given data variable, for a given grid cell. When the value for a given variable is greater than zero, the value indicates the relative risk of each $0.25^{\circ}$ grid cell to inundation or erosion, with 5 indicating the greatest risk.

Data Format - Arc/Info ${ }^{\mathrm{TM}}$ coverage and flat ASCII file with data values for each $0.25^{\circ}$ latitude by $0.25^{\circ}$ longitude grid cell on the U.S. West Coast.

File Storage - Arc/Info ${ }^{\mathrm{TM}}$ coverage name is WCRISK.EOO (File 12) ASCI file name is WCRISK.ASC (File 13).

\section{Data Variables}

ELR - Classified version of the mean elevation data variable (i.e., ELAVG).

GLR - Classified version of the geology data variable (i.e., GL).

GMR - Classified version of the geomorphology data variable (i.e., GM).

LSR - Classified version of the local subsidence trend data variable (i.e., SLS).

ERR - Classified version of the mean erosion/accretion data variable (i.e., ERAVG).

TRR - Classified version of the mean-tide-range data variable (i.e., TRAVG).

WHR - Classified version of the maximum significant wave-height variable (i.e., WHMAX). 
(3) Data Group WCLINE: 1: 2,000,000 digitized line segment data for the 22 original and 7 relative risk data variables from each of the seven data sets (i.e., elevation, geology, geomorphology, sea-level trend, shoreline displacement, tidal range, and wave heights). A value of -9999.99 or 9999 indicates no data are available for the given data cell for a given data variable.)

Data Format - Arc/Info ${ }^{\mathrm{TM}}$ coverage and flat ASCII file with data values for each line segment that describes the U.S. West Coast.

File Storage - Arc/Info ${ }^{\mathrm{TM}}$ coverage name is WCLINE.E00 (File 12) ASCII file name is WCLINE.ASC (File 13).

\section{Data Variables}

ELAVG - Average elevation calculated from all positive $5^{\prime}$ by $5^{\prime}$ grid cells within a given $0.25^{\circ}$ grid cell; values expressed in meters.

ELMAX - Maximum elevation of all the positive $5^{\prime}$ by $5^{\prime}$ grid cells for a given $0.25^{\circ}$ grid cell; values expressed in meters.

ELMON - Minimum elevation of all the positive $5^{\prime}$ by $5^{\prime}$ grid cells for a given $0.25^{\circ}$ grid cell; values expressed in meters.

ELNUM - Number of $5^{\prime}$ by $5^{\prime}$ grid cells used in calculating ELAVG, ELMIN, and ELMAX for a given $0.25^{\circ}$ grid cell.

ELR - Classified version of the mean elevation data variable (i.e., ELAVG).

GL - Ordinal value indicating the type and resistance of the rocks within a given region to erosion through physical and chemical weathering.

GLR - Classified version of the geology data variable (i.e., GL).

GM - Ordinal value indicating the type and susceptibility of the landforms within a given region to inundation and erosion.

GMR - Classified version of the geomorphology data variable (i.e., GM).

SLR - Relative sea-level trend within a given $0.25^{\circ}$ grid cell; values are expressed in $\mathrm{mm} /$ year. Data values are based on the point data in data group WCPOINT.

SLG - Geologic trend variable. In this data base this variable is 0.0 for all $0.25^{\circ}$ grid cells with a relative sea-level trend value, and -9999.99 for all grid cells without a relative sealevel trend value. This data variable has been included to ensure compatibility among the NDPs in this series (i.e., NDP-043A, NDP-043B, and NDP-043C). See Appendix D for additional geologic trends based on long-term geologic data from raised marine terraces and ${ }^{14} \mathrm{C}$ data. 
SLC - Corrected sea-level trend. Since the geologic trend variable contains values of 0.0 , this variable appears identical to the relative sea-level trend variable; and is included only for compatibility within this series of NDPs. Some long-term geologic trends are listed in Appendix D.

SLS - Local subsidence trend derived from tide-gauge data and corrected for the global eustatic sea-level trend (i.e., 1.50); values are expressed in mm/year. Data values are based on the point data in data group WCPOINT.

SLYR - Number of years of record used in estimating the sea-level trend for each $0.25^{\circ}$ grid cell (grid cells in which tide-gauge stations do not occur have been assigned a zero value.) Data values are based on the point data in data group WCPOINT.

LSR - Classified version of the local subsidence trend data variable (i.e., SLS).

ERAVG - Average of the mean long-term erosion trend values for a given $0.25^{\circ}$ grid cell; values expressed in meters.

ERMAX - Maximum of the mean long-term erosion trends for a given $0.25^{\circ}$ grid cell; values expressed in meters.

ERMIN - Minimum of the mean long-term erosion trends for a given $0.25^{\circ}$ grid cell; values expressed in meters.

ERNUM - Number of $3^{\prime}, 7.5^{\prime}$, or $15^{\prime}$ grid cells (i.e., format of original data source) used in calculating ERAVG, ERMIN, or ERMAX for a given $0.25^{\circ}$ grid cell.

ERR - Classified version of the mean erosion/accretion data variable (i.e., ERAVG).

TRAVG - Average of the mean-tide-range values for all tide stations occurring within a given $0.25^{\circ}$ grid cell in 1992 (the mean tide range is the difference in height between mean high water and mean low water for 1992). Data values are expressed in meters and are based on the point data in data group WCPOINT.

TRMAX - Maximum tide range measured for all gauge stations that occurred within a given $0.25^{\circ}$ grid cell in 1992 (this value may be the "spring" or "diurnal" tide range, depending on geographic location). Data values are expressed in meters and are based on the point data in data group WCPOINT.

TRLVL - Average of the mean-tide-level values for all tide stations occurring within a given $0.25^{\circ}$ grid cell in 1992 (the mean tide level is a plane midway between mean low water and mean high water in 1992). Values are reckoned from chart datum, are expressed in meters, and are based on the point data in data group WCPOINT. 
TRNUM - Number of tide-gauge stations used in calculating TRAVG, TRMAX, and TRLVL for a given $0.25^{\circ}$ grid cell. Data values are based on the point data in data group WCPOINT.

TRR - Classified version of the mean-tide-range data variable (i.e., TRAVG).

WHAVG - 20-year mean wave height calculated for each $0.25^{\circ}$ grid cell: values expressed in meters.

WHMAX - Maximum significant wave height for each $0.25^{\circ}$ grid cell; values expressed in meters.

WHSD - Standard deviation of the mean wave heights experienced within each $0.25^{\circ}$ grid cell; values expressed in meters.

WHR - Classified version of the maximum significant wave-height variable (i.e., WHMAX).

(4) Data Group WCPOINT: Point data for the stations used in constructing the sealevel trend and tidal-range data sets. (Missing data values are indicated by the value 0.0 for real numbers, 0 for integers, and blank spaces [i.e., ' '] for station names.)

Data Format - Arc/Info ${ }^{\mathrm{TM}}$ coverage and flat ASCII file with data values for each point (i.e., station) on the U.S. West Coast.

File Storage - Arc/Info ${ }^{\mathrm{TM}}$ coverage name is WCPOINT.E00 (File 16) ASCII file name is WCPOINT.ASC (File 17).

\section{Data Variables}

SLLONG - Longitude of the tide-gauge station used for determining the sea-level trend variables.

SLLAT - Latitude of the given tide-gauge station used for determining the sea-level trend variables.

SLR - Relative sea-level trend for the tide-gauge station; values expressed in $\mathrm{mm} /$ year.

SLG - Geologic trend variable. In this data base this variable is 0.0 for all $0.25^{\circ}$ grid cells with a relative sea-level trend value, and -9999.99 for all grid cells without a relative sealevel trend value. This data variable has been included to ensure compatibility among the NDPs in this series (i.e., NDP-043A, NDP-043B, and NDP-043C). See Appendix D for additional geologic trends based on long-term geologic data from raised marine terraces and ${ }^{14} \mathrm{C}$ data. 
SLC - Corrected sea-level trend. Since the geologic trend variable contains values of 0.0 , this variable appears identical to the relative sea-level trend variable; and is included only for compatibility within this series of NDPs. Some long-term geologic trends are listed in Appendix D.

SLS - Local subsidence trend derived from tide-gauge data and corrected for the global eustatic sea-level trend (i.e., 1.50); values are expressed in mm/year.

SLYR - Period of record in years of the tide-gauge station used for determining the sea-level trend variables.

SLNAME - Station name of the tide-gauge station used for determining the sealevel trend variables.

TRLONG - Longitude of the tide-gauge station used for determining the tide-range variables.

TRLAT - Latitude of the given tide-gauge station used for determining the tiderange variables.

TRAVG - Difference (i.e., range) in height between mean high water and mean low water in 1992; values expressed in meters.

TRMAX - Difference (i.e., range) in height between the highest high tide and the lowest low tide in 1992 (this value may be the "spring" or "diurnal" tide range, depending on geographic location); values expressed in meters.

TRLVL - Mean tide level is a plane midway between mean low water and mean high water in 1992; values expressed in meters. Values are reckoned from chart datums (i.e., the West Coast Mean Low Water Datum).

TRID - Station number (as given in the 1992 Tide Tables) of the given tide gauge station used in determining the tide-range variables.

TRNAME - Station name (as given in the 1992 Tide Tables) of the given tide gauge station used in determining the tide-range variables.

(5) Data Group WCOAST: 1:2,000,000 digitized coastline of the U.S. West Coast.

Data Format - Arc/Info ${ }^{\mathrm{TM}}$ coverage and flat ASCII file containing the latitude-longitude coordinates of line segments that describe the U.S. West Coast.

File Storage - Arc/Info ${ }^{\mathrm{TM}}$ coverage name is WCOAST.E00 (File 20) ASCI file name is WCOAST.ASC (File 21). 


\section{Data Variables}

Unlike the other data groups within this data base, this coverage contains line segments (or arcs) that are used to describe the West Coast. The coastline provided has no data variables associated with the line segments. However, simple overlay commands (such as

INTERSECT or IDENTITY) in Arc/Info ${ }^{\mathrm{TM}}$ may be used to transfer the gridded data values to the coastal segments, thus simplifying the interpretation of any derived indices. The segment identification numbers match those used in the flat ASCII file WCLINE.ASC. 
APPENDIX B: GLOSSARY OF TERMS 
. 


\section{Glossary of Terms Used in the Geologic Classification}

The following listing defines the terms that appear in the geologic classification system shown in Table 1. The codes used in the classification system are shown in parentheses. When the classification number given contains an "X" (e.g., $1 \mathrm{XX}$ ) it is implied that the definition is valid for all subsets of the given geologic feature. This list defines only those rock types mentioned within Table 1 and should not be construed as a comprehensive set of geologic definitions.

IGNEOUS ROCK (1XX) - Rock that has crystallized from a silicate melt at high temperatures (i.e., 900 to $1600^{\circ} \mathrm{C}$ ).

VOLCANIC (EXTRUSIVE) ROCK (OLD=11X) (NEW=4XX) - Igneous rock that has reached the Earth's surface as a result of eruptive processes in a molten or partially molten state. Since these rocks tend to cool rapidly they are usually fine-grained.

ANDESITE (110) - Grayish fine-grained volcanic rock composed of oligoclase/andesine (plagioclase feldspar), with lesser amounts of hornblende, biotite, or pyroxene. Potassium feldspar and quartz compose less than $10 \%$ of the total mineral content (plutonic equivalent is quartz diorite).

BASALT (110) - Dark fine-grained volcanic rock consisting of labradorite (plagioclase feldspar) and augite (pyroxene), with minor olivine (plutonic equivalent is gabbro).

RHYOLITE (110) - Light fine-grained volcanic rock composed essentially of alkali feldspar and quartz, with minor biotite occasionally present (plutonic equivalent is granite).

PLUTONIC (INTRUSIVE) ROCK (13X) - Igneous rock which has crystallized from molten material (magma) at depth and has reached the Earth's surface through uplift and erosion. Because cooling is generally slower, these rocks are coarser-grained than their volcanic equivalents.

METAMORPHIC ROCK (15X) - Rock derived from preexisting materials (either igneous, sedimentary, or metamorphic) when recrystallization occurs under higher temperatures, pressures, and shear stresses than normally exist at the Earth's surface.

GNEISS (150) - Metamorphic rock that exhibits alternating bands of lighter minerals (quartz, feldspars) and darker minerals (biotite, hornblende, pyroxene).

QUARTZITE (150) - Metamorphic rock composed essentially of quartz. It resuits from highgrade metamorphism of a quartz-rich sandstone in which recrystallization of silica has produced a tough, hard rock with interlocking quartz grains.

SCHIST (150) - Metamorphic rock characterized by a layered or foliated appearance (schistosity) cause by the planar alignment of platy minerals, such as mica together with quartz, and minor amounts of other minerals, like garnet.

SERPENTINITE (150) - Green to greenish-yellow rock composed chiefly of the mineral serpentine, derived from metamorphism of iron-magnesium-rich igneous rocks. 
SEDIMENTARY ROCK (2XX) - Rock consisting of weathered or eroded fragments of preexisting rocks that have been cemented together as a result of chemical cementation, compression, or precipitation.

SHALE (210) - Sedimentary rock consisting of very fine-grained particles $(\leq 0.004 \mathrm{~mm})$ composed chiefly of clay minerals. It is distinguished from mudstone, by its ability to split into thin layers.

SILTSTONE (220) - Sedimentary rock consisting of fine-grained particles in the size range of 0.004 to $0.062 \mathrm{~mm}$. Composed chiefly of clays and fine-grained quartz with mica.

SANDSTONE (230) - Fine to medium-grained sedimentary rock with particles in the size range between 0.062 to $2.0 \mathrm{~mm}$. Typically composed of quartz, feldspars, and rock fragments, which are cemented together by silica, calcite, iron oxide, or clay. The hardness or strength of this rock depends largely on the nature and extent of the cement.

CONGLOMERATE (240) - Coarse-grained sedimentary rock composed of boulders to granulesized particles $(>2.0 \mathrm{~mm}$ ), which are cemented together by silica, calcite, iron oxide, or clay. The hardness or strength of this rock depends largely on nature of the cement.

LIMESTONE (250) - Carbonate rock that can consist either of fragmental material, including fossils, pellets, etc., or a chemical precipitate.

EOLIANITE (260) - Layer of wind-blown beach sand often cemented by deposition of calcium carbonate. Tends to occur above the mean tide level in warm climates.

UNCONSOLIDATED SEDIMENTS (3XX) - Fragmented materials that are derived from the chemical and mechanical weathering process or from chemical precipitation and that have not yet undergone cementation and induration into a consolidated rock.

MUD, CLAY (310) - Very fine-grained particles $(\leq 0.004 \mathrm{~mm})$ of clay and quartz.

SILT (320) - Fine-grained particles $(\leq 0.062 \mathrm{~mm})$ of clay, quartz, and mica.

SAND (330) - Fine- to medium-grained particles ( 2.0 to $0.062 \mathrm{~mm}$ ) of quartz, feldspar, other heavy minerals, and rock fragments.

GRAVELS, CONGLOMERATES (340) - Coarse-grained rock fragments ( $>2.0 \mathrm{~mm}$ ), usually rounded to some degree, depending on the amount of transportation before the fragments came to rest.

GLACIAL TILL (350) - Unsorted materials, ranging in size from fine-grained "rock flour" to large boulders, deposited by glaciers (also known as glacial drift).

CALCAREOUS SEDIMENT (360) - Very fine-grained to fine-grained carbonate sediment, which can be fragmental or chemically precipitated. 
LAVA (410) - Geologically recent volcanic rock that has formed by extrusion of molten magma to the Earth's surface as a sheet or flow.

ASH, TEPHRA (420) - Tephra is the general term for all fragmental volcanic materials ejected through a surface-reaching vent. Ash is unconsolidated, fine-grained ejected material (coarsergrained fragments are called bombs, scoria, pumice, etc.).

CORAL REEF (500) - Mass of calcareous material consisting of the skeletal structures of corals, growing in situ, as well as coralline debris and chemically precipitated material. Reefs are generally built of coral, but calcareous algae and shells contribute to the reef structure in many areas.

\section{Glossary of Terms Used in the Geomorphic Classification}

The following list defines landforms and gives their associated classification values (shown in Table 2 on page 16). The terms are defined on the basis of the descriptions found in Bird (1984), Pethick (1984), Ritter (1986), Schwartz (1982), and Shepard and Wanless (1971). When the actual classification number contains an " $\mathrm{X}$ " (e.g., 222X) in the last digit, it is implied that the description is valid for all subsets of the given feature.

ALLUVIAL PLAIN SHORELINE (221X) - Intersection of broad alluvial slope, located at the base of a mountain range, with the ocean. These alluvial plains may also occur on delta coasts (222X) or outwash plains (231X).

BARRIER COASTS (212X) - In its most general sense, a barrier refers to accumulations of sand or gravel lying above high tide along a coast. These barriers may be partially or fully detached from the mainland. A barrier beach (2121) is a narrow strip of beach with a single ridge and often foredunes. A barrier island (2122) is completely surrounded by water and usually has multiple ridges, dunes, and salt marshes on the landward side of the island. It usually encloses a body of water known as a lagoon. Although barrier islands are the most common feature off the U.S. East and Gulf Coasts, they constitute $10 \%-15 \%$ of the rest of the world's shorelines. A bay barrier (2123) is a beach barrier built across an embayment and is found in areas with low tide ranges, and high to moderate wave energies.

BEACH (21XX) - A beach is generally made up of sand, cobbles, or boulders and is defined as the portion of the coastal area that is directly affected by wave action and that is terminated inland by a sea cliff, a dune field, or the presence of permanent vegetation and seaward at the breaker/plunge point (the active portion of this zone varies based on wave and tide conditions).

BEACH ROCK (2112) - Cementation of beach sand by $\mathrm{CaCO}_{3}$ in intertidal zones. Confined to warm climates.

CLIFFED COASTS (11XX) - Coasts with cliffs and other abrupt changes in slope at the ocean land interface. Cliffs indicate marine erosion and imply that the sediment supply of the given coastal segment is low. The cliffs height depends upon the topography of the hinterland, lithology of the area, and climate. 
COASTAL PLAIN (211X) - Sedimentary deposits formed on a trailing-edge coast. Trailing-edge coasts are often associated with barrier beach systems and are commonly subject to subsidence.

CORAL REEF COASTS (241X, 242X) - Shoal water area built up by secretions of $\mathrm{CaCO}_{3}$ by coral, marine algae, and other marine organisms. Reefs may form either fringing reefs that surround the shore or barrier reefs that grow at some distance from the coast and protect the coast from large waves.

CUSPATE FORELAND (2126) - Seaward projection of accumulated unconsolidated marine sand or gravel, bounded on both sides by wave-dominated coasts (indicates convergence of currents in a low-tide environment).

DELTA (222X) - Accumulations of fine-grained sedimentary deposits at the mouth of a river. The sediment is accumulating faster than wave erosion and subsidence can remove it. These are associated with mud flats (2224) and salt marshes (2225).

DROWNED KARST (1500) - Terrain with distinctive characteristics of relief and drainage arising from a high degree of rock solubility that was submerged at the end of the Wisconsin glaciation period (i.e., geologic substrate that is made of highly soluble, usually carbonate, rock).

ESTUARY COAST (133X) - Tidal mouth of a river or submerged river valley. Often defined to include any semi-enclosed coastal body of water diluted by freshwater, thus includes most bays. The estuaries are subjected to tidal influences with sedimentation rates and tidal ranges such that deltaic accumulations are absent. Also, estuaries are associated with relatively low-lying hinterlands, mud flats (1334), and salt marshes (1335).

FJORD (122X) - Narrow steep-walled, U-shaped, partially submerged glacial valley.

FIARD (123X) - Glacially eroded inlet located on low-lying rocky coasts (other terms used include sea inlets, fjardur, and firth).

ICE COAST (1400) - Coast bordered by glaciers.

LAGOON (225X) - A shallow water body separated from the open sea by sand islands (e.g., barrier islands) or coral reefs.

MANGROVE SWAMP (245X) - Coasts with tree vegetation of subtropical/tropical origin located on muddy, peaty substrates. Occur in coastal regions with low wave energies that are located in tropical and subtropical climates (occupies same ecological niche as salt marsh in temperate zones).

MUD FLATS - Located in areas with fine-grained sediments at low ends of the intertidal zone and are exposed at low tide. Found in estuaries (1334), deltaic environments (2224), and areas with marine/fluvial deposits (2254). 
OUTWASH PLAIN (231X) - A river deposition coast. Deposits are derived from meltwater from the front of a glacier. Grades from gravel near the glacier edge to sand farther away. Other types of glacial deposits include moraines (2320), composed of poorly sorted till, and drumlins (2330), hills sculpted by glaciers, that are composed of well-sorted till.

SALT MARSH - Salt-tolerant vegetation that colonizes the intertidal zones of estuaries (1335), deltas (2225), and lagoons (2255). Located on slightly higher elevations than mud flats, and vegetation zonation reflects subtle changes in elevation.

SPIT (2127) - Curved or hooked depositional feature formed by longshore drift. Often has salt marshes on landward side and beach ridges marking former positions of the shoreline. Very mobile landform.

VOLCANIC COASTS (25XX) - Coasts dominated by volcanic landforms. The coasts may be built up of lava flows (251X), ash flows (252X), peninsular and island volcanoes, or calderas (253X). Often may be flanked by coral reefs $(241 \mathrm{X})$ if the volcano has become submerged.

\section{References}

Bird, E. C. F. 1984. Coasts. Basil Blackwell Publishing, New York, New York.

Pethick, J. 1984. An Introduction to Coastal Geomorphology. Edward Anold Publishers, London, England.

Ritter, D. F. 1986. Process Geomorphology. William Brown Publishers, Dubuque, Iowa.

Schwartz, M. L. (ed.). 1982. The Encyclopedia of Beaches and Coastal Environments. Hutchinson \& Ross Publishing, Stroudsburg, Pennsylvania.

Shepard, F. P. and H. R. Wanless. 1971. Our Changing Coastline. McGraw-Hill Book Company, New York, New York. 
APPENDIX C: DATA LISTING OF GEOLOGIC AND GEOMORPHIC DATA 



\section{DATA LISTING OF THE GEOLOGIC AND GEOMORPHIC DATA OF EACH LINE SEGMENT THAT OCCURRED WITHIN EACH COASTAL GRID CELL}

The geologic and geomorphic data contained within this data base were originally obtained for 1:2,000,000 digitized line segments. These line segments ranged in length from $93 \mathrm{~m}$ to $88.7 \mathrm{~km}$ and averaged $5.8 \mathrm{~km}$ in length. When plotted, these line segments are equivalent to those found in the linebased data groups within this NDP. When gridded, more than one line segment often occurred within a coastal grid cell. When this situation occurred, the geologic or geomorphic code with the greatest total shore length within the grid cell was assigned to the entire grid cell. For example, if grid cell number 396 contained two line segments, the first having geomorphic code 2255 and covering $36.86 \%$ of the shore length within the grid cell, and the other having geomorphic code 2450 and covering $63.14 \%$ of the total shore length within the grid cell, then geomorphic code 2450 was assigned to the grid cell, along with its corresponding risk value of 3 .

To help the data user determine how this selection process may have affected the gridded data, the following tables were constructed. Table $\mathrm{C}-1$ illustrates the geologic data. It contains the identification number of each coastal grid cell, the occurring geology codes, the shore length (in meters) in each occurring geologic code, the percent of shore line with the occurring geologic code, and the risk value of the geologic code. Table 1 , in part 1 of this document, defines each geologic classification code while Table 4 illustrates the relative risk value assignment. Table $\mathrm{C}-2$ illustrates the geomorphic data. It contains the identification number of each coastal grid cell, the occurring geomorphic codes, the shore length (in meters) of each occurring geomorphic code, the percent of shoreline with each code, and the risk value of the geomorphic code. Table 2 defines each geomorphic code and Table 5 shows the ranking system used for assigning the relative risk values. 


\begin{tabular}{|c|c|c|c|c|}
\hline GRID CELL & GEOLOGIC & LENGTH & COASTLINE & RISK \\
\hline NUMBER & $C O D E$ & $(M)$ & PERCENTAGE & VALUE \\
\hline 115 & 270 & 6680.09 & 100.00 & 3 \\
\hline 116 & 270 & 9288.21 & 12.82 & 3 \\
\hline 116 & 330 & 18525.38 & 25.57 & 5 \\
\hline 116 & 370 & 44626.46 & 61.60 & 4 \\
\hline 150 & 110 & 22299.44 & 91.41 & 1 \\
\hline 150 & 330 & 2096.10 & 8.59 & 5 \\
\hline 151 & 110 & 36229.99 & 92.91 & 1 \\
\hline 151 & 270 & 845.41 & 2.17 & 3 \\
\hline 151 & 370 & 1918.61 & 4.92 & 4 \\
\hline 155 & 270 & 17850.06 & 59.53 & 3 \\
\hline 155 & 330 & 4036.00 & 13.46 & 5 \\
\hline 155 & 370 & 8097.03 & 27.01 & 4 \\
\hline 156 & 270 & 1293.70 & 10.95 & 3 \\
\hline 156 & 330 & 2157.56 & 18.26 & 5 \\
\hline 156 & 370 & 8366.17 & 70.80 & 4 \\
\hline 186 & 110 & 7510.64 & 100.00 & 1 \\
\hline 187 & 110 & 14308.05 & 100.00 & 1 \\
\hline 190 & 110 & 12684.22 & 74.68 & 1 \\
\hline 190 & 330 & 4300.43 & 25.32 & 5 \\
\hline 195 & 270 & 4467.14 & 14.10 & 3 \\
\hline 195 & 370 & 14057.03 & 44.37 & 4 \\
\hline 195 & 9999 & 13158.13 & 41.53 & 0 \\
\hline 226 & 110 & 10056.39 & 100.00 & 1 \\
\hline 227 & 110 & 5554.16 & 100.00 & 1 \\
\hline 228 & 110 & 8134.42 & 100.00 & 1 \\
\hline 230 & 270 & 21044.37 & 93.39 & 3 \\
\hline 230 & 370 & 1489.38 & 6.61 & 4 \\
\hline 231 & 110 & 9655.93 & 16.45 & 1 \\
\hline 231 & 130 & 13087.20 & 22.30 & 1 \\
\hline 231 & 270 & 29191.34 & 49.74 & 3 \\
\hline 231 & 370 & 3446.95 & 5.87 & 4 \\
\hline 231 & 9999 & 3309.91 & 5.64 & 0 \\
\hline 234 & 270 & 21560.05 & 70.34 & 3 \\
\hline 234 & 370 & 9091.45 & 29.66 & 4 \\
\hline 235 & 270 & 10771.71 & 100.00 & 3 \\
\hline 271 & 130 & 3343.24 & 12.55 & 1 \\
\hline 271 & 270 & 10431.73 & 39.17 & 3 \\
\hline 271 & 370 & 12857.70 & 48.28 & 4 \\
\hline 272 & 330 & 16417.62 & 66.52 & 5 \\
\hline 272 & 370 & 8262.54 & 33.48 & 4 \\
\hline 273 & 130 & 1685.73 & 3.49 & 1 \\
\hline 273 & 270 & 13115.41 & 27.15 & 3 \\
\hline 273 & 330 & 18614.44 & 38.54 & 5 \\
\hline 273 & 370 & 14886.52 & 30.82 & 4 \\
\hline 274 & 270 & 1000.04 & 100.00 & 3 \\
\hline
\end{tabular}




\begin{tabular}{|c|c|c|c|c|}
\hline \multicolumn{5}{|c|}{ TABLE C-1. GEOLOGIC DATA } \\
\hline GRID CELL & GEOLOGIC & LENGTH & COASTLINE & RISK \\
\hline NUMBER & $C O D E$ & $(M)$ & PERCENTAGE & VALUE \\
\hline 304 & 110 & 1484.21 & 4.09 & 1 \\
\hline 304 & 130 & 873.44 & 2.40 & 1 \\
\hline 304 & 270 & 24488.00 & 67.42 & 3 \\
\hline 304 & 370 & 9477.20 & 26.09 & 4 \\
\hline 305 & 110 & 7620.18 & 29.92 & 1 \\
\hline 305 & 270 & 11175.52 & 43.88 & 3 \\
\hline 305 & 370 & 6672.36 & 26.20 & 4 \\
\hline 306 & 110 & 9919.95 & 52.54 & 1 \\
\hline 306 & 270 & 8960.80 & 47.46 & 3 \\
\hline 311 & 130 & 3830.46 & 9.77 & 1 \\
\hline 311 & 270 & 4145.39 & 10.57 & 3 \\
\hline 311 & 330 & 24589.62 & 62.70 & 5 \\
\hline 311 & 370 & 6650.28 & 16.96 & 4 \\
\hline 312 & 330 & 5300.59 & 20.09 & 5 \\
\hline 312 & 370 & 21083.14 & 79.91 & 4 \\
\hline 343 & 110 & 11852.87 & 30.68 & 1 \\
\hline 343 & 270 & 17438.78 & 45.13 & 3 \\
\hline 343 & 330 & 6912.55 & 17.89 & 5 \\
\hline 343 & 370 & 2434.45 & 6.30 & 4 \\
\hline 344 & 110 & 1781.52 & 6.11 & 1 \\
\hline 344 & 270 & 27382.02 & 93.89 & 3 \\
\hline 345 & 110 & 18385.29 & 59.55 & 1 \\
\hline 345 & 130 & 1711.54 & 5.54 & 1 \\
\hline 345 & 270 & 4723.63 & 15.30 & 3 \\
\hline 345 & 370 & 6052.82 & 19.61 & 4 \\
\hline 346 & 110 & 20719.01 & 64.49 & 1 \\
\hline 346 & 270 & 6014.97 & 18.72 & 3 \\
\hline 346 & 370 & 2892.34 & 9.00 & 4 \\
\hline 346 & 9999 & 2500.24 & 7.78 & 0 \\
\hline 347 & 110 & 13865.95 & 69.39 & 1 \\
\hline 347 & 330 & 6117.93 & 30.61 & 5 \\
\hline 348 & 270 & 7426.48 & 14.62 & 3 \\
\hline 348 & 330 & 38901.36 & 76.57 & 5 \\
\hline 348 & 370 & 4252.26 & 8.37 & 4 \\
\hline 348 & 9999 & 227.25 & 0.45 & 0 \\
\hline 349 & 110 & 2622.15 & 10.17 & 1 \\
\hline 349 & 270 & 11002.10 & 42.68 & 3 \\
\hline 349 & 370 & 12156.14 & 47.15 & 4 \\
\hline 350 & 270 & 16428.01 & 67.20 & 3 \\
\hline 350 & 330 & 3722.60 & 15.23 & 5 \\
\hline 350 & 370 & 4294.22 & 17.57 & 4 \\
\hline 351 & 330 & 1546.08 & 100.00 & 5 \\
\hline 383 & 270 & 27311.49 & 100.00 & 3 \\
\hline 384 & 270 & 23637.05 & 100.00 & 3 \\
\hline 385 & 270 & 20009.05 & 79.28 & 3 \\
\hline
\end{tabular}




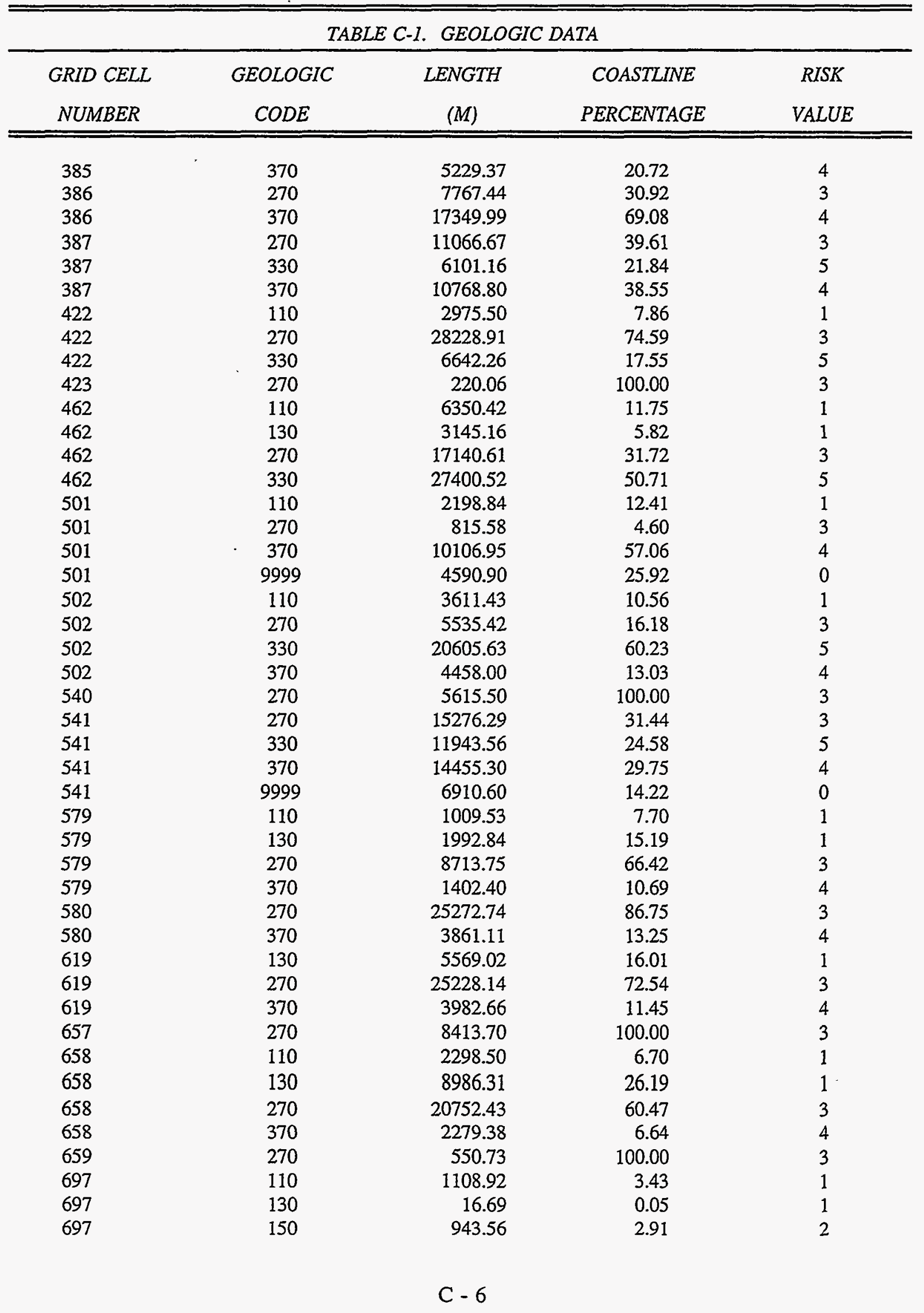




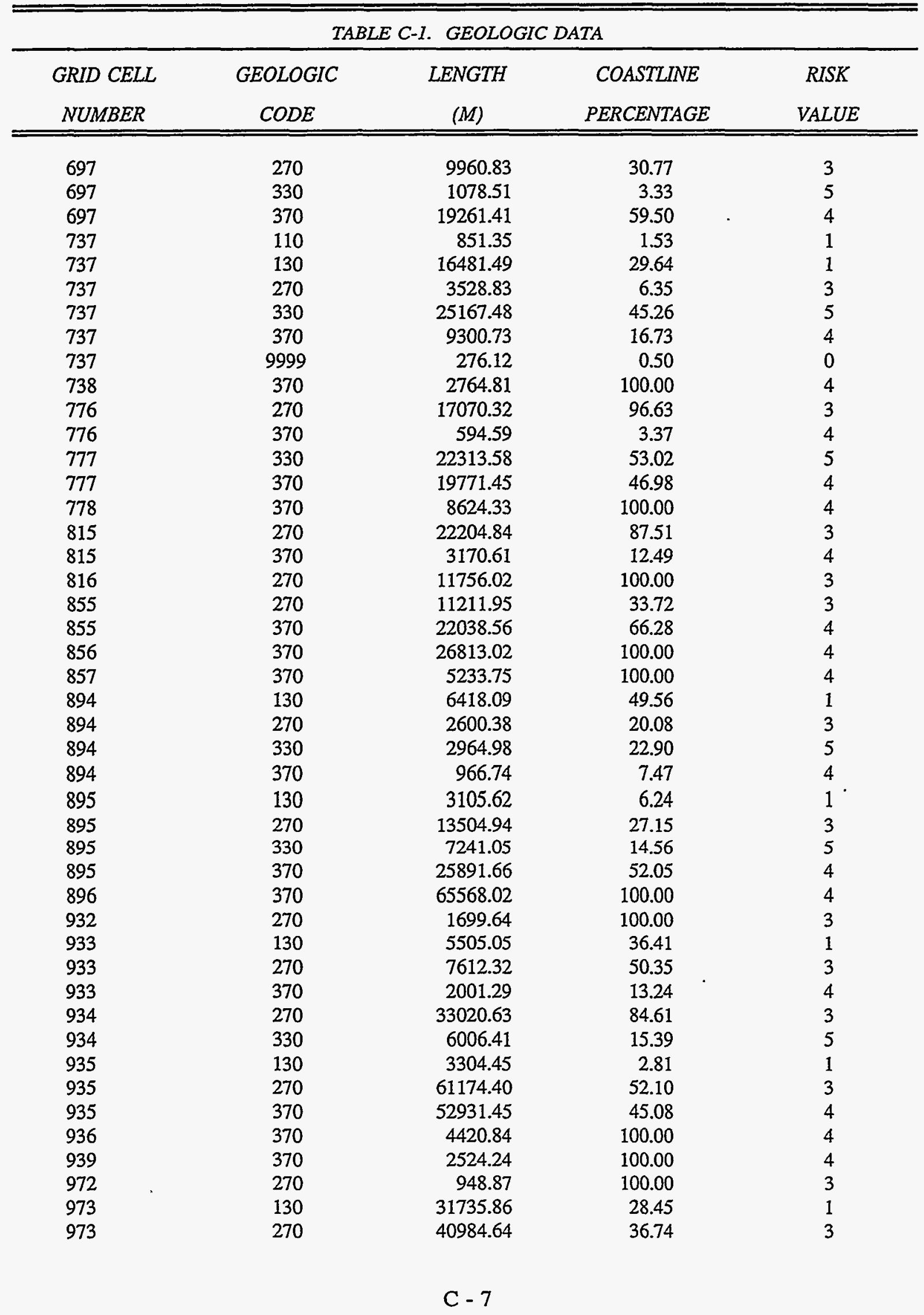




\begin{tabular}{|c|c|c|c|c|}
\hline \multicolumn{5}{|c|}{ TABLE C-1. GEOLOGIC DATA } \\
\hline GRID CELL & GEOLOGIC & LENGTH & COASTLINE & $R I S K$ \\
\hline NUMBER & $C O D E$ & $(M)$ & PERCENTAGE & VALUE \\
\hline 973 & 330 & 24268.76 & 21.75 & 5 \\
\hline 973 & 370 & 10553.03 & 9.46 & 4 \\
\hline 973 & 9999 & 4018.26 & 3.60 & 0 \\
\hline 974 & 370 & 10016.15 & 100.00 & 4 \\
\hline 975 & 270 & 17937.22 & 18.66 & 3 \\
\hline 975 & 370 & 78167.45 & 81.34 & 4 \\
\hline 976 & 270 & 28433.13 & 43.04 & 3 \\
\hline 976 & 370 & 37623.17 & 56.96 & 4 \\
\hline 977 & 370 & 99615.00 & 100.00 & 4 \\
\hline 978 & 370 & 123383.02 & 100.00 & 4 \\
\hline 979 & 370 & 15736.66 & 100.00 & 4 \\
\hline 1012 & 130 & 1590.32 & 1.96 & 1 \\
\hline 1012 & 270 & 43453.27 & 53.47 & 3 \\
\hline 1012 & 330 & 28365.42 & 34.91 & 5 \\
\hline 1012 & 370 & 7851.50 & 9.66 & 4 \\
\hline 1013 & 270 & 9964.62 & 93.88 & 3 \\
\hline 1013 & 330 & 649.63 & 6.12 & 5 \\
\hline 1050 & 270 & 2031.20 & 100.00 & 3 \\
\hline 1051 & 270 & 34463.82 & 100.00 & 3 \\
\hline 1052 & 270 & 2563.95 & 100.00 & 3 \\
\hline 1090 & 270 & 30898.03 & 84.14 & 3 \\
\hline 1090 & 370 & 5824.21 & 15.86 & 4 \\
\hline 1129 & 270 & 1713.89 & 24.77 & 3 \\
\hline 1129 & 370 & 5205.90 & 75.23 & 4 \\
\hline 1130 & 270 & 101.64 & 0.43 & 3 \\
\hline 1130 & 370 & 23306.71 & 99.57 & 4 \\
\hline 1169 & 270 & 13889.31 & 44.97 & 3 \\
\hline 1169 & 330 & 231.16 & 0.75 & 5 \\
\hline 1169 & 370 & 16767.17 & 54.28 & 4 \\
\hline 1209 & 270 & 16252.18 & 53.90 & 3 \\
\hline 1209 & 330 & 6450.42 & 21.39 & 5 \\
\hline 1209 & 370 & 7449.83 & 24.71 & 4 \\
\hline 1248 & 270 & 963.74 & 100.00 & 3 \\
\hline 1249 & 270 & 32686.37 & 100.00 & 3 \\
\hline 1287 & 270 & 10195.06 & 100.00 & 3 \\
\hline 1288 & 270 & 32940.84 & 100.00 & 3 \\
\hline 1327 & 270 & 30148.16 & 100.00 & 3 \\
\hline 1367 & 270 & 2590.88 & 8.28 & 3 \\
\hline 1367 & 330 & 24495.04 & 78.26 & 5 \\
\hline 1367 & 370 & 4212.45 & 13.46 & 4 \\
\hline 1368 & 330 & 10798.95 & 47.02 & 5 \\
\hline 1368 & 370 & 12165.96 & 52.98 & 4 \\
\hline 1408 & 330 & 41403.97 & 63.35 & 5 \\
\hline 1408 & 370 & 23952.61 & 36.65 & 4 \\
\hline 1448 & 150 & 8577.19 & 26.82 & 2 \\
\hline
\end{tabular}




\begin{tabular}{|c|c|c|c|c|}
\hline \multicolumn{5}{|c|}{ TABLE C-1. GEOLOGIC DATA } \\
\hline GRID CELL & GEOLOGIC & LENGTH & COASTLINE & $R I S K$ \\
\hline$N U M B E R$ & $C O D E$ & $(M)$ & PERCENTAGE & VALUE \\
\hline 1448 & 270 & 15189.12 & 47.50 & 3 \\
\hline 1448 & 330 & 3515.40 & 10.99 & 5 \\
\hline 1448 & 370 & 4698.48 & 14.69 & 4 \\
\hline 1488 & 150 & 4790.49 & 16.78 & 2 \\
\hline 1488 & 270 & 7805.96 & 27.34 & 3 \\
\hline 1488 & 330 & 15954.30 & 55.88 & 5 \\
\hline 1528 & 270 & 25276.71 & 46.90 & 3 \\
\hline 1528 & 330 & 28621.60 & 53.10 & 5 \\
\hline 1568 & 270 & 11453.60 & 22.48 & 3 \\
\hline 1568 & 330 & 39505.15 & 77.52 & 5 \\
\hline 1607 & $130^{\circ}$ & 1736.40 & 5.60 & 1 \\
\hline 1607 & 150 & 2184.02 & 7.04 & 2 \\
\hline 1607 & 270 & 22447.36 & 72.39 & 3 \\
\hline 1607 & 330 & 4641.11 & 14.97 & 5 \\
\hline 1608 & 330 & 4837.61 & 100.00 & 5 \\
\hline 1647 & 270 & 10613.16 & 27.10 & 3 \\
\hline 1647 & 330 & 28543.86 & 72.90 & 5 \\
\hline 1686 & 370 & 2211.27 & 100.00 & 4 \\
\hline 1687 & 130 & 3513.65 & 11.05 & 1 \\
\hline 1687 & 270 & 20220.26 & 63.57 & 3 \\
\hline 1687 & 330 & 5008.62 & 15.75 & 5 \\
\hline 1687 & 370 & 3064.67 & 9.64 & 4 \\
\hline 1726 & 370 & 22775.15 & 100.00 & 4 \\
\hline 1727 & 330 & 8696.41 & 100.00 & 5 \\
\hline 1767 & 270 & 4321.96 & 14.83 & 3 \\
\hline 1767 & 330 & 19766.14 & 67.84 & 5 \\
\hline 1767 & 370 & 5048.78 & 17.33 & 4 \\
\hline 1807 & 270 & 22507.69 & 30.21 & 3 \\
\hline 1807 & 330 & 25451.26 & 34.16 & 5 \\
\hline 1807 & 370 & 24556.65 & 32.96 & 4 \\
\hline 1807 & 9999 & 1999.80 & 2.68 & 0 \\
\hline 1808 & 270 & 20956.98 & 52.35 & 3 \\
\hline 1808 & 330 & 1169.33 & 2.92 & 5 \\
\hline 1808 & 370 & 17904.11 & 44.73 & 4 \\
\hline 1847 & 330 & 2712.04 & 100.00 & 5 \\
\hline 1848 & 270 & 46906.11 & 63.93 & 3 \\
\hline 1848 & 330 & 26459.46 & 36.07 & 5 \\
\hline 1849 & 270 & 15009.45 & 100.00 & 3 \\
\hline 1888 & 270 & 19204.36 & 33.13 & 3 \\
\hline 1888 & 330 & 31997.86 & 55.20 & 5 \\
\hline 1888 & 370 & 6769.38 & 11.68 & 4 \\
\hline 1928 & 110 & 16906.96 & 52.92 & 1 \\
\hline 1928 & 330 & 12621.22 & 39.50 & 5 \\
\hline 1928 & 370 & 2421.27 & 7.58 & 4 \\
\hline 1968 & 110 & 9839.46 & 21.26 & 1 \\
\hline
\end{tabular}




\begin{tabular}{|c|c|c|c|c|}
\hline \multicolumn{5}{|c|}{ TABLE C-1. GEOLOGIC DATA } \\
\hline GRID CELL & GEOLOGIC & LENGTH & COASTLINE & RISK \\
\hline NUMBER & $C O D E$ & $(M)$ & PERCENTAGE & VALUE \\
\hline 1968 & 130 & 3456.82 & 7.47 & 1 \\
\hline 1968 & 270 & 32974.57 & 71.26 & 3 \\
\hline 2008 & 110 & 10766.80 & 21.11 & 1 \\
\hline 2008 & 270 & 40242.54 & 78.89 & 3 \\
\hline 2009 & 270 & 13391.00 & 100.00 & 3 \\
\hline 2048 & 110 & 10640.42 & 28.59 & 1 \\
\hline 2048 & 270 & 959.97 & 2.58 & 3 \\
\hline 2048 & 330 & 19838.93 & 53.31 & 5 \\
\hline 2048 & 370 & 5771.69 & 15.51 & 4 \\
\hline 2088 & 110 & 10219.15 & 66.95 & 1 \\
\hline 2088 & 270 & 3142.16 & 20.59 & 3 \\
\hline 2088 & 370 & 1901.85 & 12.46 & 4 \\
\hline 2089 & 110 & 6044.94 & 9.94 & 1 \\
\hline 2089 & 270 & 10351.76 & 17.03 & 3 \\
\hline 2089 & 330 & 26465.72 & 43.53 & 5 \\
\hline 2089 & 370 & 17933.56 & 29.50 & 4 \\
\hline 2128 & 110 & 112.38 & 100.00 & 1 \\
\hline 2129 & 110 & 13624.07 & 23.14 & 1 \\
\hline 2129 & 270 & 4336.24 & 7.37 & 3 \\
\hline 2129 & 330 & 28053.64 & 47.66 & 5 \\
\hline 2129 & 370 & 12850.59 & 21.83 & 4 \\
\hline 2169 & 110 & 4921.88 & 6.98 & 1 \\
\hline 2169 & 270 & 17987.99 & 25.50 & 3 \\
\hline 2169 & 330 & 26183.28 & 37.12 & 5 \\
\hline 2169 & 370 & 21447.93 & 30.40 & 4 \\
\hline 2209 & 110 & 7784.48 & 22.15 & 1 \\
\hline 2209 & 270 & 18240.69 & 51.90 & 3 \\
\hline 2209 & 330 & 9120.68 & 25.95 & 5 \\
\hline 2248 & 330 & 3058.16 & 100.00 & 5 \\
\hline 2249 & 110 & 4968.76 & 5.89 & 1 \\
\hline 2249 & 270 & 14467.02 & 17.14 & 3 \\
\hline 2249 & 330 & 30160.33 & 35.72 & 5 \\
\hline 2249 & 370 & 34830.13 & 41.26 & 4 \\
\hline 2250 & 270 & 12189.67 & 21.54 & 3 \\
\hline 2250 & 370 & 44400.71 & 78.46 & 4 \\
\hline 2251 & 110 & 14835.29 & 22.00 & 1 \\
\hline 2251 & 270 & 8149.44 & 12.08 & 3 \\
\hline 2251 & 370 & 44461.54 & 65.92 & 4 \\
\hline 2288 & 110 & 11888.03 & 20.56 & 1 \\
\hline 2288 & 270 & 4303.73 & 7.44 & 3 \\
\hline 2288 & 330. & 34780.43 & 60.15 & 5 \\
\hline 2288 & 370 & 6850.46 & 11.85 & 4 \\
\hline 2289 & 110 & 4975.29 & 5.99 & 1 \\
\hline 2289 & 130 & 2189.78 & 2.64 & 1 \\
\hline 2289 & 270 & 39212.87 & 47.25 & 3 \\
\hline
\end{tabular}




\begin{tabular}{|c|c|c|c|c|}
\hline \multicolumn{5}{|c|}{ TABLE C-1. GEOLOGIC DATA } \\
\hline GRID CELL & GEOLOGIC & LENGTH & COASTLINE & $R I S K$ \\
\hline$N U M B E R$ & $C O D E$ & $(M)$ & PERCENTAGE & VALUE \\
\hline 2289 & 370 & 36617.77 & 44.12 & 4 \\
\hline 2290 & 110 & 13133.12 & 50.74 & 1 \\
\hline 2290 & 270 & 6070.31 & 23.45 & 3 \\
\hline 2290 & 370 & 6680.41 & 25.81 & 4 \\
\hline 2291 & 110 & 1639.48 & 11.61 & 1 \\
\hline 2291 & 370 & 12482.57 & 88.39 & 4 \\
\hline 2328 & 330 & 39755.95 & 82.90 & 5 \\
\hline 2328 & 370 & 8199.08 & 17.10 & 4 \\
\hline 2329 & 110 & 4178.44 & 5.16 & 1 \\
\hline 2329 & 270 & 470.14 & 0.58 & 3 \\
\hline 2329 & 370 & 76266.68 & 94.26 & 4 \\
\hline 2368 & 330 & 40644.01 & 50.92 & 5 \\
\hline 2368 & 370 & 39178.74 & 49.08 & 4 \\
\hline 2408 & 330 & 17064.64 & 37.26 & 5 \\
\hline 2408 & 370 & 28730.84 & 62.74 & 4 \\
\hline 2412 & 345 & 69526.26 & 100.00 & 4 \\
\hline 2413 & 345 & 164886.03 & 100.00 & 4 \\
\hline 2414 & 345 & 90515.48 & 100.00 & 4 \\
\hline 2447 & 110 & 1969.81 & 6.53 & 1 \\
\hline 2447 & 270 & 21833.32 & 72.37 & 3 \\
\hline 2447 & 370 & 6364.55 & 21.10 & 4 \\
\hline 2448 & 370 & 5481.99 & 100.00 & 4 \\
\hline 2452 & 110 & 8772.45 & 13.40 & 1 \\
\hline 2452 & 345 & 56707.14 & 86.60 & 4 \\
\hline 2453 & 345 & 99894.36 & 100.00 & 4 \\
\hline 2454 & 345 & 129866.39 & 100.00 & 4 \\
\hline 2455 & 345 & 93634.72 & 93.92 & 4 \\
\hline 2455 & 370 & 6062.63 & 6.08 & 4 \\
\hline 2487 & 270 & 10926.71 & 36.97 & 3 \\
\hline 2487 & 370 & 18627.94 & 63.03 & 4 \\
\hline 2492 & 110 & 11031.68 & 68.71 & 1 \\
\hline 2492 & 345 & 5023.09 & 31.29 & 4 \\
\hline 2493 & 110 & 26019.69 & 33.97 & 1 \\
\hline 2493 & 345 & 50584.41 & 66.03 & 4 \\
\hline 2494 & 110 & 3331.77 & 2.02 & 1 \\
\hline 2494 & 345 & 161394.35 & 97.98 & 4 \\
\hline 2495 & 345 & 50201.87 & 73.31 & 4 \\
\hline 2495 & 370 & 18276.48 & 26.69 & 4 \\
\hline 2526 & 270 & 23039.97 & 79.17 & 3 \\
\hline 2526 & 370 & 6063.08 & 20.83 & 4 \\
\hline 2527 & 270 & 9447.74 & 100.00 & 3 \\
\hline 2533 & 110 & 13897.57 & 31.37 & 1 \\
\hline 2533 & 345 & 30403.52 & 68.63 & 4 \\
\hline 2534 & 110 & 8259.71 & 7.48 & 1 \\
\hline 2534 & 270 & 4032.59 & 3.65 & 3 \\
\hline
\end{tabular}




\begin{tabular}{|c|c|c|c|c|}
\hline GRID CELL & GEOLOGIC & LENGTH & COASTLINE & RISK \\
\hline NUMBER & $C O D E$ & $(M)$ & PERCENTAGE & VALUE \\
\hline 2534 & 345 & 98199.52 & 88.87 & 4 \\
\hline 2535 & 345 & 63948.22 & 100.00 & 4 \\
\hline 2536 & 345 & 6263.40 & 100.00 & 4 \\
\hline 2565 & 270 & 2380.59 & 100.00 & 3 \\
\hline 2566 & 110 & 1952.53 & $5: 91$ & 1 \\
\hline 2566 & 230 & 2289.03 & 6.93 & 3 \\
\hline 2566 & 270 & 19140.03 & 57.92 & 3 \\
\hline 2566 & 345 & 8520.52 & 25.78 & 4 \\
\hline 2566 & 370 & 1145.15 & 3.47 & 4 \\
\hline 2567 & 270 & 1806.37 & 100.00 & 3 \\
\hline 2568 & 270 & 22529.85 & 100.00 & 3 \\
\hline 2569 & 270 & 20146.49 & 100.00 & 3 \\
\hline 2570 & 110 & 6455.94 & 30.59 & 1 \\
\hline 2570 & 270 & 1697.11 & 8.04 & 3 \\
\hline 2570 & 345 & 5700.90 & 27.01 & 4 \\
\hline 2570 & 370 & 7253.71 & 34.37 & 4 \\
\hline 2571 & 270 & 6413.53 & 22.71 & 3 \\
\hline 2571 & 345 & 21821.37 & 77.29 & 4 \\
\hline 2572 & 110 & 1146.13 & 2.15 & 1 \\
\hline 2572 & 270 & 9685.60 & 18.15 & 3 \\
\hline 2572 & 345 & 42546.83 & 79.71 & 4 \\
\hline 2573 & 110 & 5513.28 & 7.24 & 1 \\
\hline 2573 & 270 & 18822.70 & 24.72 & 3 \\
\hline 2573 & 345 & 51808.11 & 68.04 & 4 \\
\hline 2574 & 110 & 10820.44 & 7.23 & 1 \\
\hline 2574 & 270 & 21276.35 & 14.21 & 3 \\
\hline 2574 & 345 & 117590.91 & 78.56 & 4 \\
\hline 2575 & 345 & 99540.58 & 99.59 & 4 \\
\hline 2575 & 370 & 410.11 & 0.41 & 4 \\
\hline 2576 & 345 & 4919.91 & 22.67 & 4 \\
\hline 2576 & 370 & 16779.74 & 77.33 & 4 \\
\hline 2605 & 270 & 723.43 & 100.00 & 3 \\
\hline 2606 & 110 & 2236.99 & 5.47 & 1 \\
\hline 2606 & 230 & 3837.19 & 9.38 & 3 \\
\hline 2606 & 270 & 27202.92 & 66.47 & 3 \\
\hline 2606 & 370 & 7647.95 & 18.69 & 4 \\
\hline 2607 & 270 & 21276.53 & 100.00 & 3 \\
\hline 2608 & 270 & 1851.11 & 100.00 & 3 \\
\hline 2612 & 270 & 14093.54 & 81.50 & 3 \\
\hline 2612 & 345 & 3198.97 & 18.50 & 4 \\
\hline 2613 & 110 & 2525.17 & 4.53 & 1 \\
\hline 2613 & 270 & 3831.04 & 6.88 & 3 \\
\hline 2613 & 345 & 49352.07 & 88.59 & 4 \\
\hline 2614 & 130 & 9690.60 & 7.78 & 1 \\
\hline 2614 & 270 & 1902.62 & 1.53 & 3 \\
\hline
\end{tabular}




\begin{tabular}{|c|c|c|c|c|}
\hline \multicolumn{5}{|c|}{ TABLE C-1. GEOLOGIC DATA } \\
\hline GRID CELL & GEOLOGIC & LENGTH & COASTLINE & $R I S K$ \\
\hline NUMBER & $C O D E$ & $(M)$ & PERCENTAGE & VALUE \\
\hline 2614 & 345 & 110375.23 & 88.57 & 4 \\
\hline 2614 & 370 & 2650.95 & 2.13 & 4 \\
\hline 2615 & 270 & 4284.63 & 12.95 & 3 \\
\hline 2615 & 345 & 12686.86 & 38.36 & 4 \\
\hline 2615 & 370 & 16104.05 & 48.69 & 4 \\
\hline 2652 & 130 & 5508.25 & 4.69 & 1 \\
\hline 2652 & 270 & 97635.00 & 83.12 & 3 \\
\hline 2652 & 345 & 14323.42 & 12.19 & 4 \\
\hline 2653 & 130 & 17861.96 & 10.69 & 1 \\
\hline 2653 & 270 & 94148.06 & 56.34 & 3 \\
\hline 2653 & 345 & 30984.76 & 18.54 & 4 \\
\hline 2653 & 9999 & 24126.22 & 14.44 & 0 \\
\hline 2654 & 130 & 14880.36 & 11.23 & 1 \\
\hline 2654 & 270 & 37691.74 & 28.44 & 3 \\
\hline 2654 & 345 & 76584.02 & 57.79 & 4 \\
\hline 2654 & 370 & 2807.53 & 2.12 & 4 \\
\hline 2654 & 9999 & 558.32 & 0.42 & 0 \\
\hline 2655 & 270 & 13855.87 & 49.11 & 3 \\
\hline 2655 & 345 & 2565.38 & 9.09 & 4 \\
\hline 2655 & 370 & 11792.40 & 41.80 & 4 \\
\hline 2692 & 370 & 15319.38 & 100.00 & 4 \\
\hline 2693 & 270 & 11343.78 & 26.63 & 3 \\
\hline 2693 & 345 & 31248.38 & 73.37 & 4 \\
\hline 2694 & 345 & 29315.98 & 86.09 & 4 \\
\hline 2694 & 370 & 4738.29 & 13.91 & 4 \\
\hline 2695 & 345 & 1180.53 & 100.00 & 4 \\
\hline
\end{tabular}

C -13 


\begin{tabular}{|c|c|c|c|c|}
\hline GRID CELL & GEOMORPHIC & LENGTH & COASTLINE & $R I S K$ \\
\hline$N U M B E R$ & $C O D E$ & $(M)$ & PERCENTAGE & VALUE \\
\hline 115 & 1120 & 6108.50 & 91.44 & 2 \\
\hline 115 & 2259 & 571.59 & 8.56 & 4 \\
\hline 116 & 1120 & 8626.03 & 11.91 . & 2 \\
\hline 116 & 2129 & 15755.53 & 21.75 & 5 \\
\hline 116 & 2259 & 45911.24 & 63.38 & 4 \\
\hline 116 & 9999 & 2147.26 & 2.96 & 0 \\
\hline 150 & 1110 & 8064.36 & 33.06 & 3 \\
\hline 150 & 1120 & 15558.34 & 63.78 & 2 \\
\hline 150 & 1130 & 772.84 & 3.17 & 1 \\
\hline 151 & 1110 & 10863.11 & 27.86 & 3 \\
\hline 151 & 1111 & 3185.13 & 8.17 & 4 \\
\hline 151 & 1120 & 6318.33 & 16.20 & 2 \\
\hline 151 & 1130 & 18627.44 & 47.77 & 1 \\
\hline 155 & 1120 & 6135.11 & 20.46 & 2 \\
\hline 155 & 1121 & 16804.69 & 56.05 & 3 \\
\hline 155 & 2121 & 6678.53 & 22.27 & 5 \\
\hline 155 & 2259 & 364.75 & 1.22 & 4 \\
\hline 156 & 2259 & 11817.42 & 100.00 & 4 \\
\hline 186 & 1110 & 7510.64 & 100.00 & 3 \\
\hline 187 & 1110 & 11117.06 & 77.70 & 3 \\
\hline 187 & 2127 & 3190.98 & 22.30 & 5 \\
\hline 190 & 1110 & 13515.57 & 79.58 & 3 \\
\hline 190 & 1120 & 3469.06 & 20.42 & 2 \\
\hline 195 & 1111 & 30870.26 & 97.44 & 4 \\
\hline 195 & 1121 & 812.04 & 2.56 & 3 \\
\hline 226 & 1110 & 10056.39 & 100.00 & 3 \\
\hline 227 & 1110 & 5554.16 & 100.00 & 3 \\
\hline 228 & 1120 & 8134.42 & 100.00 & 2 \\
\hline 230 & 1130 & 22533.76 & 100.00 & 1 \\
\hline 231 & 1130 & 58691.32 & 100.00 & 1 \\
\hline 234 & 1111 & 17986.85 & 58.68 & 4 \\
\hline 234 & 1121 & 12664.66 & 41.32 & 3 \\
\hline 235 & 1111 & 10714.78 & 99.47 & 4 \\
\hline 235 & 1121 & 56.93 & 0.53 & 3 \\
\hline 271 & 1120 & 14979.89 & 56.25 & 2 \\
\hline 271 & 2219 & 11652.77 & 43.75 & 4 \\
\hline 272 & 2219 & 24680.16 & 100.00 & 4 \\
\hline 273 & 1121 & 15099.28 & 31.26 & 3 \\
\hline 273 & 2129 & 6152.45 & 12.74 & 5 \\
\hline 273 & 2219 & 7617.26 & 15.77 & 4 \\
\hline 273 & 2259 & 19433.11 & 40.23 & 4 \\
\hline 274 & 1121 & 1000.04 & 100.00 & 3 \\
\hline 304 & 1110 & 5779.23 & 15.91 & 3 \\
\hline 304 & 1111 & 1757.53 & 4.84 & 4 \\
\hline 304 & 1120 & 27626.31 & 76.06 & 2 \\
\hline
\end{tabular}




\begin{tabular}{|c|c|c|c|c|}
\hline GRID CELL & GEOMORPHIC & LENGTH & COASTLINE & $R I S K$ \\
\hline NUMBER & $C O D E$ & $(M)$ & PERCENTAGE & VALUE \\
\hline 304 & 9999 & 1159.76 & 3.19 & 0 \\
\hline 305 & 1110 & 7987.73 & 31.36 & 3 \\
\hline 305 & 1120 & 2657.60 & 10.44 & 2 \\
\hline 305 & 1130 & 11978.63 & 47.03 & 1 \\
\hline 305 & 1131 & 2844.09 & 11.17 & 2 \\
\hline 306 & 1130 & 18880.74 & 100.00 & 1 \\
\hline 311 & 1111 & 13133.38 & 33.49 & 4 \\
\hline 311 & 1119 & 5757.23 & 14.68 & 3 \\
\hline 311 & 1120 & 8828.79 & 22.51 & 2 \\
\hline 311 & 2211 & 5324.26 & 13.58 & 5 \\
\hline 311 & 2219 & 6172.09 & 15.74 & 4 \\
\hline 312 & 2219 & 26383.74 & 100.00 & 4 \\
\hline 343 & 1110 & 25948.09 & 67.16 & 3 \\
\hline 343 & 1111 & 11569.71 & 29.94 & 4 \\
\hline 343 & 2127 & 1120.83 & 2.90 & 5 \\
\hline 344 & 1111 & 9928.21 & 34.04 & 4 \\
\hline 344 & 1120 & 19235.34 & 65.96 & 2 \\
\hline 345 & 1120 & 9856.13 & 31.92 & 2 \\
\hline 345 & 1130 & 21017.14 & 68.08 & 1 \\
\hline 346 & 1120 & 4950.05 & 15.41 & 2 \\
\hline 346 & 1130 & 22023.37 & 68.55 & 1 \\
\hline 346 & 1131 & 5153.14 & 16.04 & 2 \\
\hline 347 & 1130 & 13865.95 & 69.39 & 1 \\
\hline 347 & 2211 & 5073.86 & 25.39 & 5 \\
\hline 347 & 2219 & 1044.07 & 5.22 & 4 \\
\hline 348 & 1130 & 7980.19 & 15.71 & 1 \\
\hline 348 & 2127 & 4517.43 & 8.89 & 5 \\
\hline 348 & 2211 & 23185.45 & 45.63 & 5 \\
\hline 348 & 2219 & 4569.39 & 8.99 & 4 \\
\hline 348 & 2259 & 10327.64 & 20.33 & 4 \\
\hline 348 & 9999 & 227.25 & 0.45 & 0 \\
\hline 349 & 1110 & 3392.95 & 13.16 & 3 \\
\hline 349 & 1111 & 5672.18 & 22.00 & 4 \\
\hline 349 & 1130 & 7074.98 & 27.44 & 1 \\
\hline 349 & 1131 & 9640.30 & 37.39 & 2 \\
\hline 350 & 1121 & 8726.81 & 35.70 & 3 \\
\hline 350 & 1130 & 3968.74 & 16.24 & 1 \\
\hline 350 & 1131 & 7448.48 & 30.47 & 2 \\
\hline 350 & 2211 & 4300.80 & 17.59 & 5 \\
\hline 351 & 2211 & 1546.08 & 100.00 & 5 \\
\hline 383 & 1110 & 15457.55 & 56.60 & 3 \\
\hline 383 & 1120 & 3413.54 & 12.50 & 2 \\
\hline 383 & 1130 & 8440.40 & 30.90 & 1 \\
\hline 384 & 1111 & 17973.20 & 76.04 & 4 \\
\hline 384 & 1130 & 5663.85 & 23.96 & 1 \\
\hline
\end{tabular}




\begin{tabular}{|c|c|c|c|c|}
\hline GRID CELL & GEOMORPHIC & LENGTH & COASTLINE & RISK \\
\hline NUMBER & $C O D E$ & $(M)$ & PERCENTAGE & VALUE \\
\hline 385 & 1111 & 16832.91 & 66.70 & 4 \\
\hline 385 & 1120 & 343.95 & 1.36 & 2 \\
\hline 385 & 2121 & 8061.57 & 31.94 & 5 \\
\hline 386 & 1111 & 12140.14 & 48.33 & 4 \\
\hline 386 & 1120 & 4774.96 & 19.01 & 2 \\
\hline 386 & 1130 & 931.77 & 3.71 & 1 \\
\hline 386 & 2121 & 7270.56 & 28.95 & 5 \\
\hline 387 & 1121 & 8120.94 & 29.07 & 3 \\
\hline 387 & 1130 & 12842.95 & 45.97 & 1 \\
\hline 387 & 2219 & 6972.75 & 24.96 & 4 \\
\hline 422 & 1110 & 11577.39 & 30.59 & 3 \\
\hline 422 & 1120 & 17404.72 & 45.99 & 2 \\
\hline 422 & 2211 & 8864.55 & 23.42 & 5 \\
\hline 423 & 1120 & 220.06 & 100.00 & 2 \\
\hline 462 & 1110 & 10347.52 & 19.15 & 3 \\
\hline 462 & 1120 & 10125.70 & 18.74 & 2 \\
\hline 462 & 2211 & 33563.51 & 62.11 & 5 \\
\hline 501 & 1130 & 13121.36 & 74.08 & 1 \\
\hline 501 & 9999 & 4590.90 & 25.92 & 0 \\
\hline 502 & 1111 & 8774.21 & 25.65 & 4 \\
\hline 502 & 1121 & 6072.73 & 17.75 & 3 \\
\hline 502 & 1130 & 1879.02 & 5.49 & 1 \\
\hline 502 & 1131 & 5653.10 & 16.52 & 2 \\
\hline 502 & 2211 & 11831.43 & 34.58 & 5 \\
\hline 540 & 1120 & 5615.50 & 100.00 & 2 \\
\hline 541 & 1110 & 7232.53 & 14.89 & 3 \\
\hline 541 & 1111 & 5565.80 & 11.46 & 4 \\
\hline 541 & 1120 & 10576.50 & 21.77 & 2 \\
\hline 541 & 1130 & 629.94 & 1.30 & 1 \\
\hline 541 & 2121 & 8372.75 & 17.23 & 5 \\
\hline 541 & 2250 & 15323.36 & 31.54 & 4 \\
\hline 541 & 9999 & 884.88 & 1.82 & 0 \\
\hline 579 & 1110 & 11871.78 & 90.50 & 3 \\
\hline 579 & 1130 & 1246.72 & 9.50 & 1 \\
\hline 580 & 1110 & 9399.01 & 32.26 & 3 \\
\hline 580 & 1120 & 2294.94 & 7.88 & 2 \\
\hline 580 & 1121 & 17439.90 & 59.86 & 3 \\
\hline 619 & 1130 & 34779.82 & 100.00 & 1 \\
\hline 657 & 1120 & 6.01 & 0.07 & 2 \\
\hline 657 & 1130 & 8407.69 & 99.93 & 1 \\
\hline 658 & 1130 & 34316.63 & 100.00 & 1 \\
\hline 659 & $1130^{\circ}$ & 550.73 & 100.00 & 1 \\
\hline 697 & 1120 & 10948.46 & 33.82 & 2 \\
\hline 697 & 1130 & 21421.44 & 66.18 & 1 \\
\hline 737 & 1110 & 17882.84 & 32.16 & 3 \\
\hline
\end{tabular}




\begin{tabular}{|c|c|c|c|c|}
\hline GRID CELL & GEOMORPHIC & LENGTH & COASTLINE & RISK \\
\hline NUMBER & $C O D E$ & $(M)$ & PERCENTAGE & VALUE \\
\hline 737 & $11: 11$ & 8312.55 & 14.95 & 4 \\
\hline 737 & 1130 & 2387.86 & 4.29 & 1 \\
\hline 737 & 1335 & 8168.42 & 14.69 & 3 \\
\hline 737 & 2211 & 18578.20 & 33.41 & 5 \\
\hline 737 & 9999 & 276.12 & 0.50 & 0 \\
\hline 738 & 1335 & 2764.81 & 100.00 & 3 \\
\hline 776 & 1110 & 15884.52 & 89.92 & 3 \\
\hline 776 & 1119 & 1780.39 & 10.08 & 3 \\
\hline 777 & 1111 & 7622.01 & 18.11 & 4 \\
\hline 777 & 1119 & 9104.69 & 21.63 & 3 \\
\hline 777 & 1335 & 2264.04 & 5.38 & 3 \\
\hline 777 & 2211 & 23094.30 & 54.88 & 5 \\
\hline 778 & 1335 & 8624.33 & 100.00 & 3 \\
\hline 815 & 1110 & 18197.50 & 71.71 & 3 \\
\hline 815 & 1120 & 3357.93 & 13.23 & 2 \\
\hline 815 & 1121 & 3820.01 & 15.05 & 3 \\
\hline 816 & 1110 & 2993.79 & 25.47 & 3 \\
\hline 816 & 1120 & 8762.23 & 74.53 & 2 \\
\hline 855 & 1110 & 848.90 & 2.55 & 3 \\
\hline 855 & 1111 & 20839.37 & 62.67 & 4 \\
\hline 855 & 1121 & 11562.24 & 34.77 & 3 \\
\hline 856 & 1335 & 26813.02 & 100.00 & 3 \\
\hline 857 & 1335 & 5233.75 & 100.00 & 3 \\
\hline 894 & 1110 & 912.35 & 7.05 & 3 \\
\hline 894 & 1111 & 6791.05 & 52.44 & 4 \\
\hline 894 & 1130 & 5246.79 & 40.52 & 1 \\
\hline 895 & 1110 & 1545.93 & 3.11 & 3 \\
\hline 895 & 1111 & 7241.05 & 14.56 & 4 \\
\hline 895 & 1120 & 6683.80 & 13.44 & 2 \\
\hline 895 & 1130 & 1072.41 & 2.16 & 1 \\
\hline 895 & 1339 & 33200.07 & 66.74 & 4 \\
\hline 896 & 1335 & 39414.94 & 60.11 & 3 \\
\hline 896 & 1339 & 26153.08 & 39.89 & 4 \\
\hline 932 & 1110 & 1104.13 & 64.96 & 3 \\
\hline 932 & 1130 & 595.50 & 35.04 & 1 \\
\hline 933 & 1120 & 8767.59 & 57.99 & 2 \\
\hline 933 & 1121 & 600.62 & 3.97 & 3 \\
\hline 933 & 1130 & 5677.34 & 37.55 & 1 \\
\hline 933 & 9999 & 73.11 & 0.48 & 0 \\
\hline 934 & 1110 & 5043.62 & 12.92 & 3 \\
\hline 934 & 1111 & 3351.30 & 8.59 & 4 \\
\hline 934 & 1120 & 17583.62 & 45.05 & 2 \\
\hline 934 & 2121 & 5350.77 & 13.71 & 5 \\
\hline 934 & 2250 & 7697.73 & 19.72 & 4 \\
\hline 935 & 1111 & 6430.51 & 5.48 & 4 \\
\hline
\end{tabular}




\begin{tabular}{|c|c|c|c|c|}
\hline GRID CELL & GEOMORPHIC & $L E N G T H$ & COASTLINE & $R I S K$ \\
\hline NUMBER & $C O D E$ & $(M)$ & PERCENTAGE & VALUE \\
\hline 935 & 1120 & 13968.09 & 11.90 & 2 \\
\hline 935 & 1330 & 33900.55 & 28.87 & 4 \\
\hline 935 & 1339 & 56562.29 & 48.17 & 4 \\
\hline 935 & 9999 & 6548.84 & 5.58 & 0 \\
\hline 936 & 1339 & 4420.84 & 100.00 & 4 \\
\hline 939 & 1330 & 2524.24 & 100.00 & 4 \\
\hline 972 & 1110 & 948.87 & 100.00 & 3 \\
\hline 973 & 1110 & 29997.69 & 26.89 & 3 \\
\hline 973 & 1111 & 7191.99 & 6.45 & 4 \\
\hline 973 & 1121 & 6677.75 & 5.99 & 3 \\
\hline 973 & 1330 & 64920.76 & 58.19 & 4 \\
\hline 973 & 2121 & 2505.72 & 2.25 & 5 \\
\hline 973 & 9999 & 266.64 & 0.24 & 0 \\
\hline 974 & 1330 & 10016.15 & 100.00 & 4 \\
\hline 975 & 1120 & 2170.48 & 2.26 & 2 \\
\hline 975 & 1330 & 83512.28 & 86.90 & 4 \\
\hline 975 & 1339 & 10421.89 & 10.84 & 4 \\
\hline 976 & 1120 & 7940.54 & 12.02 & 2 \\
\hline 976 & 1330 & 58115.76 & 87.98 & 4 \\
\hline 977 & 1330 & 99615.00 & 100.00 & 4 \\
\hline 978 & 1330 & 123383.02 & 100.00 & 4 \\
\hline 979 & 1330 & 15736.66 & 100.00 & 4 \\
\hline 1012 & 1110 & 45875.77 & 56.46 & 3 \\
\hline 1012 & 1111 & 6055.96 & 7.45 & 4 \\
\hline 1012 & 1330 & 8114.86 & 9.99 & 4 \\
\hline 1012 & 2121 & 7628.78 & 9.39 & 5 \\
\hline 1012 & 2250 & 12651.40 & 15.57 & 4 \\
\hline 1012 & 9999 & 933.72 & 1.15 & 0 \\
\hline 1013 & 1110 & 10614.24 & 100.00 & 3 \\
\hline 1050 & 1110 & 2031.20 & 100.00 & 3 \\
\hline 1051 & 1110 & 34463.82 & 100.00 & 3 \\
\hline 1052 & 1110 & 2563.95 & 100.00 & 3 \\
\hline 1090 & 1110 & 31095.94 & 84.68 & 3 \\
\hline 1090 & 2111 & 5626.30 & 15.32 & 5 \\
\hline 1129 & 1110 & 6919.79 & 100.00 & 3 \\
\hline 1130 & 1110 & 21109.49 & 90.18 & 3 \\
\hline 1130 & 2111 & 2298.85 & 9.82 & 5 \\
\hline 1169 & 1110 & 25485.50 & 82.51 & 3 \\
\hline 1169 & 2111 & 5402.13 & 17.49 & 5 \\
\hline 1209 & 1110 & 5648.08 & 18.73 & 3 \\
\hline 1209 & 1130 & 18754.96 & 62.20 & 1 \\
\hline 1209 & 2111 & 5749.38 & 19.07 & 5 \\
\hline 1248 & 1130 & 963.74 & 100.00 & 1 \\
\hline 1249 & 1130 & 32686.37 & 100.00 & 1 \\
\hline 1287 & 1130 & 10195.06 & 100.00 & 1 \\
\hline
\end{tabular}




\begin{tabular}{|c|c|c|c|c|}
\hline GRID CELL & GEOMORPHIC & $L E N G T H$ & COASTLINE & RISK \\
\hline NUMBER & $C O D E$ & $(M)$ & PERCENTAGE & VALUE \\
\hline 1288 & 1130 & 30103.73 & 91.39 & 1 \\
\hline 1288 & 1131 & 2837.11 & 8.61 & 2 \\
\hline 1327 & 1130 & 30148.16 & 100.00 & 1 \\
\hline 1367 & 1130 & 5915.90 & 18.90 & 1 \\
\hline 1367 & 2127 & 2662.12 & 8.51 & 5 \\
\hline 1367 & 2221 & 22720.35 & 72.59 & 5 \\
\hline 1368 & 2127 & 3871.20 & 16.86 & 5 \\
\hline 1368 & 2250 & 19093.70 & 83.14 & 4 \\
\hline 1408 & 1110 & 29004.54 & 44.38 & 3 \\
\hline 1408 & 2127 & 922.98 & 1.41 & 5 \\
\hline 1408 & 2250 & 35429.07 & 54.21 & 4 \\
\hline 1448 & 1110 & 22657.38 & 70.85 & 3 \\
\hline 1448 & 2121 & 9322.81 & 29.15 & 5 \\
\hline 1488 & 1110 & 6961.21 & 24.38 & 3 \\
\hline 1488 & 1111 & 15809.98 & 55.38 & 4 \\
\hline 1488 & 1120 & 5779.56 & 20.24 & 2 \\
\hline 1528 & 1110 & 3955.34 & 7.34 & 3 \\
\hline 1528 & 1111 & 17884.98 & 33.18 & 4 \\
\hline 1528 & 1120 & 24431.60 & 45.33 & 2 \\
\hline 1528 & 1330 & 7626.42 & 14.15 & 4 \\
\hline 1568 & 1110 & 10898.14 & 21.39 & 3 \\
\hline 1568 & 1111 & 33887.84 & 66.50 & 4 \\
\hline 1568 & 2121 & 1573.77 & 3.09 & 5 \\
\hline 1568 & 2250 & 4599.00 & 9.02 & 4 \\
\hline 1607 & 1111 & 5022.88 & 16.20 & 4 \\
\hline 1607 & 1120 & 14817.25 & 47.78 & 2 \\
\hline 1607 & 1121 & 11168.76 & 36.02 & 3 \\
\hline 1608 & 1111 & 4837.61 & 100.00 & 4 \\
\hline 1647 & 1120 & 9840.68 & 25.13 & 2 \\
\hline 1647 & 1121 & 19059.65 & 48.67 & 3 \\
\hline 1647 & 1130 & 10256.69 & 26.19 & 1 \\
\hline 1686 & 1110 & 2210.24 & 99.95 & 3 \\
\hline 1686 & 1111 & 1.03 & 0.05 & 4 \\
\hline 1687 & 1110 & 477.99 & 1.50 & 3 \\
\hline 1687 & 1111 & 3431.98 & 10.79 & 4 \\
\hline 1687 & 1120 & 22206.75 & 69.82 & 2 \\
\hline 1687 & 1121 & 5690.48 & 17.89 & 3 \\
\hline 1726 & 1110 & 7320.90 & 32.14 & 3 \\
\hline 1726 & 1111 & 15454.25 & 67.86 & 4 \\
\hline 1727 & 1110 & 8696.41 & 100.00 & 3 \\
\hline 1767 & 1110 & 19395.55 & 66.57 & 3 \\
\hline 1767 & 2111 & 9741.32 & 33.43 & 5 \\
\hline 1807 & 1110 & 1483.87 & 1.99 & 3 \\
\hline 1807 & .1120 & 15103.19 & 20.27 & 2 \\
\hline 1807 & 1330 & 21529.55 & 28.89 & 4 \\
\hline
\end{tabular}




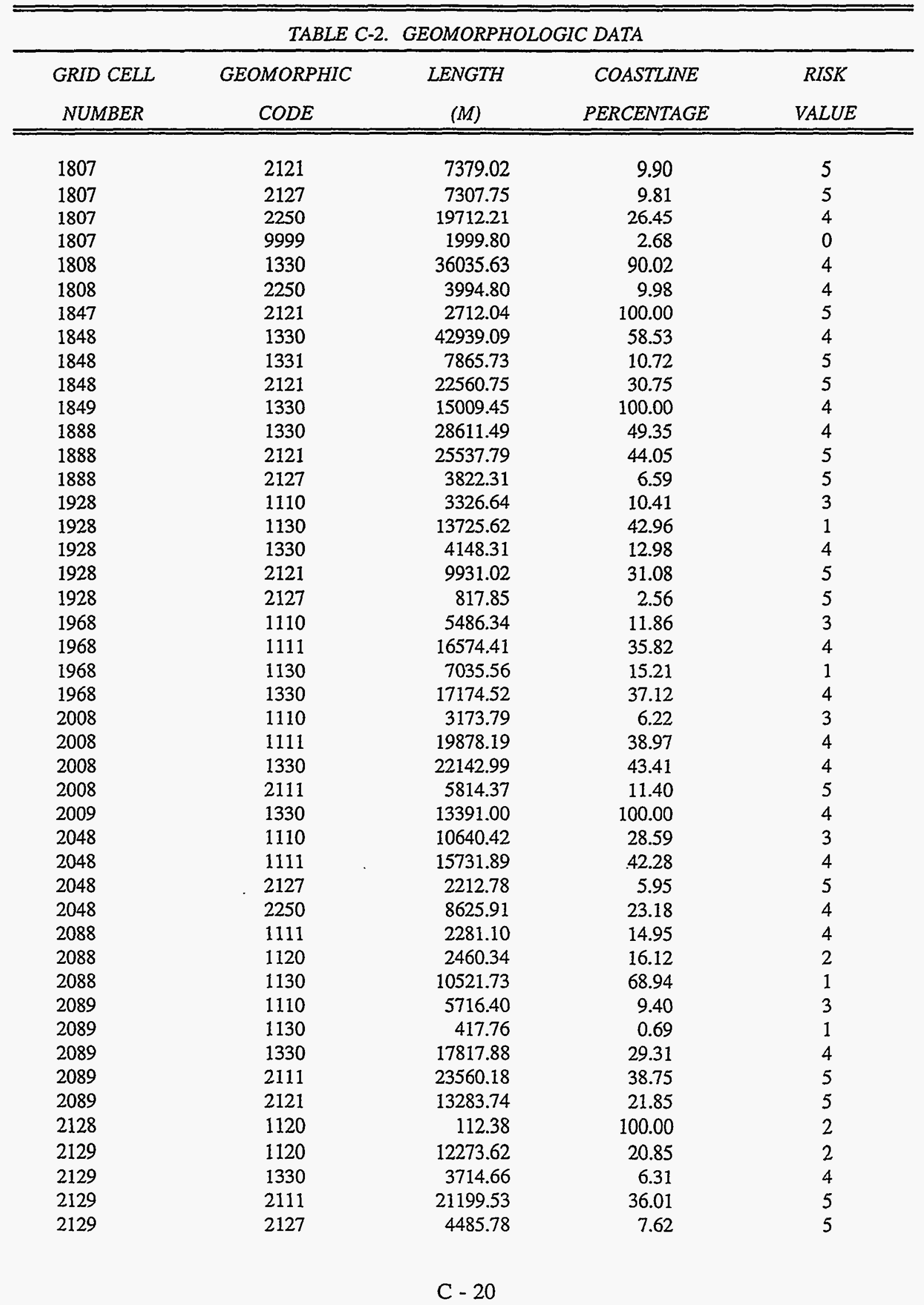




\begin{tabular}{|c|c|c|c|c|}
\hline GRID.CELL & GEOMORPHIC & LENGTH & COASTLINE & RISK \\
\hline NUMBER & $C O D E$ & $(M)$ & PERCENTAGE & VALUE \\
\hline 2129 & 2220 & 3909.34 & 6.64 & 5 \\
\hline 2129 & 2250 & 13281.63 & 22.56 & 4 \\
\hline 2169 & 1130 & 1915.27 & 2.72 & 1 \\
\hline 2169 & 1330 & 37707.50 & 53.45 & 4 \\
\hline 2169 & 2111 & 4077.44 & 5.78 & 5 \\
\hline 2169 & 2121 & 10210.38 & 14.47 & 5 \\
\hline 2169 & 2122 & 8984.36 & 12.74 & 5 \\
\hline 2169 & 2127 & 5266.01 & 7.47 & 5 \\
\hline 2169 & 2220 & 2380.11 & 3.37 & 5 \\
\hline 2209 & 1111 & 6820.96 & 19.41 & 4 \\
\hline 2209 & 1120 & 22387.54 & 63.70 & 2 \\
\hline 2209 & 1130 & 887.83 & 2.53 & 1 \\
\hline 2209 & 2121 & 5049.51 & 14.37 & 5 \\
\hline 2248 & 2127 & 3058.16 & 100.00 & 5 \\
\hline 2249 & 1330 & 54496.28 & 64.55 & 4 \\
\hline 2249 & 2121 & 22132.04 & 26.21 & 5 \\
\hline 2249 & 2127 & 7797.93 & 9.24 & 5 \\
\hline 2250 & 1330 & 56590.38 & 100.00 & 4 \\
\hline 2251 & 1330 & 67446.28 & 100.00 & 4 \\
\hline 2288 & 1111 & 14618.41 & 25.28 & 4 \\
\hline 2288 & 1330 & 3763.50 & 6.51 & 4 \\
\hline 2288 & 2122 & 4813.20 & 8.32 & 5 \\
\hline 2288 & 2250 & 34627.54 & .59.89 & 4 \\
\hline 2289 & 1330 & 40329.10 & 48.59 & 4 \\
\hline 2289 & 2250 & 42666.61 & 51.41 & 4 \\
\hline 2290 & 1330 & 25883.85 & 100.00 & 4 \\
\hline 2291 & 1330 & 14122.04 & 100.00 & 4 \\
\hline 2328 & 2121 & 2522.00 & 5.26 & 5 \\
\hline 2328 & 2127 & 9024.26 & 18.82 & 5 \\
\hline 2328 & 2250 & 36408.77 & 75.92 & 4 \\
\hline 2329 & 1330 & 55739.71 & 68.89 & 4 \\
\hline 2329 & 2250 & 25175.56 & 31.11 & 4 \\
\hline 2368 & 1330 & 18618.07 & 23.32 & 4 \\
\hline 2368 & 2121 & 30166.38 & 37.79 & 5 \\
\hline 2368 & 2127 & 2558.66 & 3.21 & 5 \\
\hline 2368 & 2250 & 20560.67 & 25.76 & 4 \\
\hline 2368 & 2255 & 7918.98 & 9.92 & 3 \\
\hline 2369 & 1330 & 31994.72 & 81.85 & 4 \\
\hline 2369 & 2250 & 7092.59 & 18.15 & 4 \\
\hline 2408 & 1111 & 13447.65 & 29.36 & 4 \\
\hline 2408 & 2121 & 15142.00 & 33.06 & 5 \\
\hline 2408 & 2250 & 9220.90 & 20.13 & 4 \\
\hline 2408 & 2255 & 7984.92 & 17.44 & 3 \\
\hline 2412 & 1220 & 69526.26 & 100.00 & 1 \\
\hline 2413 & 1220 & 164886.03 & 100.00 & 1 \\
\hline
\end{tabular}




\begin{tabular}{|c|c|c|c|c|}
\hline GRID CELL & GEOMORPHIC & LENGTH & COASTLINE & $R I S K$ \\
\hline NUMBER & $C O D E$ & $(M)$ & PERCENTAGE & VALUE \\
\hline 2414 & 1220 & 85288.17 & 94.22 & 1 \\
\hline 2414 & 2349 & 5227.32 & 5.78 & 3 \\
\hline 2447 & 1110 & 6202.54 & 20.56 & 3 \\
\hline 2447 & 1111 & 17628.86 & 58.44 & 4 \\
\hline 2447 & 1130 & 6336.28 & 21.00 & 1 \\
\hline 2448 & 1111. & 5481.99 & 100.00 & 4 \\
\hline 2452 & 1220 & 65479.59 & 100.00 & 1 \\
\hline 2453 & 1220 & 99894.36 & 100.00 & 1 \\
\hline 2454 & 1220 & 117288.46 & 90.31 & 1 \\
\hline 2454 & 2340 & 5781.45 & 4.45 & 3 \\
\hline 2454 & 2349 & 6796.48 & 5.23 & 3 \\
\hline 2455 & 1220 & 52850.65 & 53.01 & 1 \\
\hline 2455 & 2340 & 5167.61 & 5.18 & 3 \\
\hline 2455 & 2349 & 41679.08 & 41.81 & 3 \\
\hline 2487 & 1111 & 16152.31 & 54.65 & 4 \\
\hline 2487 & 1120 & 13402.34 & 45.35 & 2 \\
\hline 2492 & 1220 & 16054.77 & 100.00 & 1 \\
\hline 2493 & 1220 & 76604.10 & 100.00 & 1 \\
\hline 2494 & 1220 & 164726.12 & 100.00 & 1 \\
\hline 2495 & 1220 & 10830.94 & 15.82 & 1 \\
\hline 2495 & 2349 & 57647.41 & 84.18 & 3 \\
\hline 2526 & 1110 & 11004.20 & 37.81 & 3 \\
\hline 2526 & 1111 & 13667.21 & 46.96 & 4 \\
\hline 2526 & 1120 & 4431.64 & 15.23 & 2 \\
\hline 2527 & 1120 & 9447.74 & 100.00 & 2 \\
\hline 2533 & 1220 & 44301.09 & 100.00 & 1 \\
\hline 2534 & 1220 & 102678.76 & 92.93 & 1 \\
\hline 2534 & 2340 & 7813.06 & 7.07 & 3 \\
\hline 2535 & 1220 & 7356.95 & 11.50 & 1 \\
\hline 2535 & 2340 & 27842.27 & 43.54 & 3 \\
\hline 2535 & 2349 & 28749.00 & 44.96 & 3 \\
\hline 2536 & 2349 & 6263.40 & 100.00 & 3 \\
\hline 2565 & 1110 & 2380.59 & 100.00 & 3 \\
\hline 2566 & 1110 & 19404.50 & 58.72 & 3 \\
\hline 2566 & 1111 & 13642.75 & 41.28 & 4 \\
\hline 2567 & 1221 & 1806.37 & 100.00 & 2 \\
\hline 2568 & 1220 & 22529.85 & 100.00 & 1 \\
\hline 2569 & 1220 & 20146.49 & 100.00 & 1 \\
\hline 2570 & 1220 & 8322.17 & 39.43 & 1 \\
\hline 2570 & 2220 & 12785.48 & 60.57 & 5 \\
\hline 2571 & 1220 & 7534.84 & 26.69 & 1 \\
\hline 2571 & 1229 & 6572.00 & 23.28 & 1 \\
\hline 2571 & 2127 & 9627.86 & 34.10 & 5 \\
\hline 2571 & 2220 & 4500.21 & 15.94 & 5 \\
\hline 2572 & 1220 & 12816.61 & 24.01 & 1 \\
\hline
\end{tabular}




\begin{tabular}{|c|c|c|c|c|}
\hline GRID CELL & GEOMORPHIC & LENGTH & COASTLINE & RISK \\
\hline NUMBER & $C O D E$ & (M) & PERCENTAGE & VALUE \\
\hline 2572 & 2127 & 22315.55 & 41.81 & 5 \\
\hline 2572 & 2220 & 18246.41 & 34.18 & 5 \\
\hline 2573 & 1220 & 70758.58 & 92.93 & 1 \\
\hline 2573 & 2340 & 5385.53 & 7.07 & 3 \\
\hline 2574 & 1220 & 47177.51 & 31.52 & 1 \\
\hline 2574 & 2340 & 102510.19 & 68.48 & 3 \\
\hline 2575 & 2220 & 7790.65 & 7.79 & 5 \\
\hline 2575 & 2340 & 92160.04 & 92.21 & 3 \\
\hline 2576 & 2340 & 19302.17 & 88.95 & 3 \\
\hline 2576 & 2349 & 2397.47 & 11.05 & 3 \\
\hline 2605 & 1120 & 723.43 & 100.00 & 2 \\
\hline 2606 & 1110 & 2426.01 & 5.93 & 3 \\
\hline 2606 & 1111 & 11296.12 & 27.60 & 4 \\
\hline 2606 & 1120 & 13642.19 & 33.33 & 2 \\
\hline 2606 & 1220 & 8436.07 & 20.61 & 1 \\
\hline 2606 & 1221 & 5124.66 & 12.52 & 2 \\
\hline 2607 & 1220 & 17551.72 & 82.49 & 1 \\
\hline 2607 & 1221 & 3724.93 & 17.51 & 2 \\
\hline 2608 & 1220 & 1427.92 & 77.14 & 1 \\
\hline 2608 & 1221 & 423.08 & 22.86 & 2 \\
\hline 2612 & 1230 & 17292.50 & 100.00 & 1 \\
\hline 2613 & 1230 & 54395.72 & 97.64 & 1 \\
\hline 2613 & 2340 & 1312.53 & 2.36 & 3 \\
\hline 2614 & 1110 & 29287.28 & 23.50 & 3 \\
\hline 2614 & 1230 & 7237.32 & 5.81 & 1 \\
\hline 2614 & 2220 & 1515.76 & 1.22 & 5 \\
\hline 2614 & 2340 & 86579.05 & 69.47 & 3 \\
\hline 2615 & 2220 & 23928.82 & 72.35 & 5 \\
\hline 2615 & 2340 & 9146.72 & 27.65 & 3 \\
\hline 2652 & 1230 & 117466.68 & 100.00 & 1 \\
\hline 2653 & 1220 & 3284.94 & 1.97 & 1 \\
\hline 2653 & 1230 & 163836.05 & 98.03 & 1 \\
\hline 2654 & 1110 & 9851.29 & 7.43 & 3 \\
\hline 2654 & 1130 & 11353.53 & 8.57 & 1 \\
\hline 2654 & 1230 & $6^{\prime} 1801.84$ & 46.64 & 1 \\
\hline 2654 & 2127 & 9424.45 & 7.11 & 5 \\
\hline 2654 & 2220 & 896.93 & 0.68 & 5 \\
\hline 2654 & 2250 & 83.42 & 0.06 & 4 \\
\hline 2654 & 2340 & 39110.49 & 29.51 & 3 \\
\hline 2655 & 1130 & 9835.34 & 34.86 & 1 \\
\hline 2655 & 2220 & 4511.54 & 15.99 & 5 \\
\hline 2655 & 2250 & 10081.92 & 35.73 & 4 \\
\hline 2655 & 2340 & 3784.86 & 13.41 & 3 \\
\hline 2692 & 2340 & 15319.38 & 100.00 & 3 \\
\hline 2693 & 1230 & 11343.78 & 26.63 & 1 \\
\hline
\end{tabular}




\begin{tabular}{lcccc}
\hline \multicolumn{5}{c}{ TABLE C-2. } \\
\hline GRID CELL & GEOMORPHIC & LENGTH & COASTLINE & RISK \\
NUMBER & CODE & $(M)$ & PERCENTAGE & VALUE \\
\hline \hline & & & & \\
2693 & 2127 & 3764.30 & 8.84 & 5 \\
2693 & 2250 & 6616.55 & 15.53 & 4 \\
2693 & 2340 & 20867.53 & 48.99 & 3 \\
2694 & 2127 & 4027.58 & 11.83 & 5 \\
2694 & 2220 & 2903.22 & 8.53 & 5 \\
2694 & 2250 & 3258.98 & 9.57 & 4 \\
2694 & 2254 & 3725.70 & 10.94 & 5 \\
2694 & 2340 & 20138.78 & 59.14 & 3 \\
2695 & 2340 & 1180.53 & 100.00 & 3 \\
& & & & \\
\hline
\end{tabular}

C -24 
APPENDIX D: GEOLOGIC TRENDS SUPPLEMENT 


\section{Relative.Sea-Level Rise and Vertical Land Motions, U.S. West Coast}

Vivien Gornitz, December 1997

\section{Introduction}

Uplift or subsidence rates, as inferred from sea-level data (Woodworth 1995; Spencer and Woodworth 1993) or geodetic measurements (e.g., Mitchell et al. 1994) represent one important factor in assessing the vulnerability of a coastal segment to future sea-level rise. This appendix briefly outlines a procedure for estimating uplift or subsidence rates and correcting tide gauges for geologic factors caused by vertical land motions. Geologic data on rates of vertical land motion along the West Coast are summarized in Table 1 and Figure 1. Historical data from tide gauges are shown in Table 2 and Figure 2.

Data registered on West Coast tide gauges represent relative sea-level changes. These include long-term geologic trends of tectonic and possible glacio-isostatic origin, also more recent neotectonic motions (interseismic uplift; Mitchell et al. 1994), in addition to the mean global sea level rise of 1-2 mm/yr attributed to worldwide warming over the last 100 years (Houghton et al. 1996). The relative sea-level trend, in $\mathrm{mm} / \mathrm{yr}$, at any tide-gauge station can be expressed as:

$$
S L R=S L G+I+E+T S
$$

where:

$$
\begin{aligned}
& \text { SLR = Recent sea-level curve from the tide-gauge data. } \\
& \text { SLG = Long-term geologic trend (late Quaternary } \leq 125,000 \text { years), recording uplift from raised marine }
\end{aligned}
$$

\section{Relative Sea-Level Trends (SLR)}

Sea-level data for the U.S. West Coast are obtained from 16 tide-gauge stations with records at least 20 years in length (although some records may contain discontinuities; Woodworth 1995; Spencer and Woodworth 1993). The sea-level trends are derived by fitting a linear least-squares regression line to the time series of mean annual sea-level elevations for each of the 16 tide-gauge stations (Table 2; Figure 2). The average relative sea-level trend for the West Coast is $1.39 \pm 1.48 \mathrm{~mm} / \mathrm{yr}$. This value implies the prevalence of global sea-level rise and land subsidence; however, the high variability points to the presence of localized uplift (negative relative sea-level trends) in some areas, particularly in Neah Bay, WA, Astoria, OR, and Crescent City, CA. The spatial pattern of relative sea-level changes observed from tide gauges is consistent with geodetic surveys (Mitchell et al., 1994). The much higher rates of subsidence or uplift from recent relative sea-level data (Table 2; Figure 2) as compared with long-term geologic trends derived from the raised marine terraces from the same localities (Table 1; Figure 1), indicates accumulated interseismic strain and points to potential earthquake hazards (Mitchell et al. 1994).

\section{Uplift or Subsidence Trends (SLS)}

The local uplift or subsidence trend (SLS) is the difference between the relative sea-level trend (SLR) recorded by the tide gauges and the mean global eustatic $(E)$ trend of $1.5 \mathrm{~mm} / \mathrm{yr}$.

$$
\mathrm{D}-3
$$




$$
\mathrm{SLS}=\mathrm{SLR}-1.5
$$

The SLS term is a composite of long-term tectonic (SLG) and isostatic components (I), as well as more recent neotectonic motions (Ts).

Assessments of coastal vulnerability are concerned with the relative sea-level rise, inasmuch as this parameter is directly related to flood hazard. But since the SLR term contains local uplift or subsidence trends in addition to the global trend, the SLS term (as estimated by Equation 2) needs to be isolated, in order to adjust the local response to future global sea-level rise. However, the further breakdown of the individual components to the total vertical land motion is not essential for hazards assessment. As shown in Table 4 (p. 26) of this NDP, coastal segments with local subsidence trends of $+2 \mathrm{~mm} / \mathrm{yr}$ or more are at greater risk.

\section{Long-term Geologic Trends (SLG)}

The coastal region north of the Mendocino triple junction, California, marked by the convergence of three tectonic plates (e.g., the North American, Pacific, and Juan de Fuca-Gorda Plates), is characterized by oblique, offshore crustal subduction, with convergence rates of $30-50 \mathrm{~mm} / \mathrm{yr}$. In contrast, the coast to the south of the triple junction is dominated by right-lateral strike-slip motion (up to $56 \mathrm{~mm} / \mathrm{yr}$ ) associated with the San Andreas fault system. Despite this pronounced difference in tectonic style of deformation, raised Quaternary marine terraces indicate uplift along most of the West Coast, both north and south of the triple junction (Figure 1), except where active transverse structures deform the coast (Goldfinger et al. 1992), often resulting in subsidence (Table 1). Evidence for subsidence caused by a number of discrete seismic events, one as recent as 1700, is recorded in sediments from marshes and bays (e.g., Atwater 1987; Atwater et al. 1991; Darienzo et al. 1994; Peterson et al. 1997; Table 1).

Late Quaternary ( $\leq 125,000$ years) raised marine terraces, which occur along much of the West Coast, integrate the permanent uplift caused by multiple earthquake cycles over the last few hundred thousand years. Knowing the present elevation and age of at least one raised terrace, and the paleosealevel position at that time relative to the present mean sea level, one can calculate an average long-term uplift rate (Lajoie et al. 1991). Thus, raised terrace data can be used to derive a long-term average uplift trend. On the whole, late Quaternary uplift rates along the Pacific coast from Washington to California are low $(<0.6 \mathrm{~mm} / \mathrm{yr}$; Figure 1; Table 1), except in the vicinity of the Mendocino triple junction, the Ventura anticline and Cape Blanco.

\section{Correction of Relative Sea-Level Trends}

The corrected sea-level trend (SLC) for each tide-gauge is obtained by subtracting the long-term geologic trend (SLG), the glacial isostatic trend (I), and short-term (neotectonic) movements (Ts) from the relative sea-level trend (SLR).

$$
S L C=S L R-S L G-I-T S
$$

In passive plate margin settings such as the U.S. East Coast, the corrected sea-level trend (SLC) provides an approximation of the recent eustatic sea-level rise (Gornitz and Seeber 1990; Gornitz 1995).

Glacial isostatic trends (I) (based on the ICE-3G model of Tushingham and Peltier 1991; Douglas 1991) are not available for all of the tide-gauge stations in Table 2. Furthermore, the residual isostatic motions predicted by the ICE- $3 \mathrm{G}$ model are not in agreement with geological field observations which suggest little or no isostatic movements within the last 6000-7000 years in the Pacific Northwest (Mathews et al. 1970; Dethier et al. 1995). An improved glacial isostatic model, ICE-4G (Peltier 1994), has not yet been applied to 
tide-gauge data. For these reasons, no isostatic corrections are made, and $I$ is assumed to be zero. Thus, SLC $=$ SLR - SLG - Ts.

On the tectonically-active West Coast, the SLC term may still include a recent neotectonic component, Ts. Satellite-based geodetic techniques, such as GPS, are being used to resolve the inherent ambiguity between sea-level variations and vertical crustal motions, by establishing the absolute land motion with respect to the earth's center (Baker 1993). These space-geodetic methods will yield an independent measure of the total vertical motion, including Ts.

\section{References}

Atwater, B.F., 1987. Science, 236, 942-944.

Atwater, B.F., et al., 1991. Nature, 353, 156-158.

Baker, T.F., 1993. Glob. \& Planet. Change, 8, 149-159.

Bucknam, R.C. and Barnhard, T.P., 1989. EOS, 70 (43), 1332.

Byrne, R. et al., 1994. GSA Abstr. with Prog., 26(7), 530.

Darienzo, M.E. and Peterson, C.D., 1990. Tectonics, 9, 1-22.

Darienzo, M.E., et al., 1994. J. Coast. Res., 10, 850-876.

Dethier, D.P., et al., 1995. Geol. Soc. Am. Bull., 107, 1288-1303.

Douglas, B., 1991. J. Gëophys. Res., 96, 6981-6992.

Goldfinger, C., et al., 1992. Geology, 20, 141-144.

Gornitz, V., 1995. J. Coast. Res., Spec. Issue No. 17, 287-297.

Gornitz, V. and Seeber, L., 1990. Tectonophys., 178, 127-150.

Gornitz, V.M. and White, T.W., 1990. A Coastal Hazards Data Base for the U.S. East Coast, ORNL/CDIAC-45, NDP-043A.

Hanson, K.L. et al., 1994. Geol. Soc. Am. Spec. Paper 292, 45-71.

Houghton, J.T., et al., eds., 1996. Climate Change 1995--the Science of Climate Change, Cambridge University Press, Cambridge, U.K., Chap. 7, Changes in Sea Level, pp. 359-405.

Kelsey, H.M. and Bockheim, J.G., 1994. Geol. Soc. Am. Bull., 106, 840-854.

Kelsey, H.M. et al., 1994. J. Geophys. Res., 99, 12,245-12,255.

Kelsey, H.M. et al., 1996. Geol. Soc. Am. Bull., 108, 843-860.

Kennedy, G.L. et al., 1995. GSA Abstr. with Prog., 27(6), 375.

Kern, J.P., 1977. Geol. Soc. Am. Bull., 88, 1553-1566.

$$
\text { D - } 5
$$


Lajoie, K.R. and Sarna-Wojcicki, A.M., 1982. GSA Abstr. with Prog. 14(4), 179.

Lajoie, K.R. et al., 1982. In: Neotectonics in Southern California, Geol. Soc. Am. Cord. Section 78th Annual Meeting, Guidebook, J.D. Cooper, compiler, pp. 43-51.

Lajoie, K.R., et al., 1991. In: Quaternary Nonglacial Geology: Conterminous United States, Geol. Soc. Am. Decade of North Americal Geology, v. K-2, R.B. Morrison, ed., pp. 190-214.

Mathews, W.H., et al., 1970. Can. J. Earth. Sci., 7, 690-702.

Mayer, L., 1987. In: Cenozoic Basin Development of Coastal California, R.V. Ingersoll and W.G. Ernst, eds., Prentice-Hall, Inc. N.J., pp. 299-320.

McInelly, G. W. and Kelsey, H.M., 1990. J. Geophys. Res., 95, 6699-6713.

McKittrick, M.A., 1988. GSA Abstr. with Prog., 20 (3), 214.

Merritts, D. and Bull, W.B., 1989. Geology, 17, 1020-1024.

Mitchell, C.E., et al., 1994. J. Geophys. Res., 99, 12,257-12,277.

Muhs, D.R. et al., 1987. GSA Abstr. with Prog., 19, 780-781.

Muhs, D.R., et al., 1989. Quat. Int. 1, 19-34.

Muhs, D.R., et al., 1990. J. Geophys. Res., 95, 6685-6698.

Peltier, W.R., 1994. Science, 265, 195-201.

Peterson, C.D., Barnett, E.T., Briggs, G.G., Carver, G.A., Clague, J.J., and Darienzo, M.E., 1997. Estimates of coastal subsidence from great earthquakes in the Cascadia subduction zone, Vancouver island, B.C., Washington, Oregon, and northernmost California: Oregon Dept. Geology and Min. Industries Open-File Report O-97-5, 44 pp.

Phipps, J.B. and Peterson, C., 1989. EOS, 70(43), 1332.

Sherrod, B.L. and Leopold, E.B., 1995. GSA Abstr. with Prog., 27(6), 365.

Shlemon, R.J., 1979. GSA Abstr. with Prog., 11, 127.

Spencer, N.E. and Woodworth, P. L., 1993. Data Holdings of the Permanent Service for Mean Sea Level (Nov. 1993), Birkenhead, U.K., 81p.

Tushingham, A.M. and Peltier, W.R., 1991. J. Geophys. Res., 96, 4497-4523.

Woodworth, P.L., 1995. PSMSL Annual Report for 1995.

Wells, L.E., et al., 1994. GSA Abstr. with Prog., 26(7), 530.

West, D.O. and McCrumb, D.R., 1988. Geology, 16, 169-172.

$$
\text { D }-6
$$


Table 1. Long-term geologic trends (SLG), U.S. West Coast, in mm/yr.

\begin{tabular}{|c|c|c|c|c|c|}
\hline Locality & Latitude & Longitude & $\begin{array}{l}\text { Land Motion } \\
\mathrm{mm} / \mathrm{yr}\end{array}$ & $\begin{array}{l}\text { Period } \\
10^{3} \text { yrs }\end{array}$ & References \\
\hline $\begin{array}{l}\text { Restoration } \\
\text { Point, Bain- } \\
\text { bridge Is. }\end{array}$ & $4730 \mathrm{~N}$ & $12230 \mathrm{~W}$ & -4.1 & 1.7 & $\begin{array}{l}\text { Bucknam and } \\
\text { Barnhard, } 1989 .\end{array}$ \\
\hline $\begin{array}{l}\text { Restoration } \\
\text { Point, Bain- } \\
\text { bridge Is. }\end{array}$ & $4730 \mathrm{~N}$ & $12230 \mathrm{~W}$ & -6.4 & 1.1 & $\begin{array}{l}\text { Sherrod and } \\
\text { Leopold, } 1995 .\end{array}$ \\
\hline La Push & $4755 \mathrm{~N}$ & $12438 W$ & -0.5 & 82 & $\begin{array}{l}\text { West and } \\
\text { McCrumb, } 1988 .\end{array}$ \\
\hline Kalaloch & $4735 N$ & $12425 W$ & -0.3 & 82 & $\begin{array}{l}\text { West and } \\
\text { McCrumb, } 1988 .\end{array}$ \\
\hline $\begin{array}{l}\text { Near Cape } \\
\text { Elizabeth }\end{array}$ & $4730 \mathrm{~N}$ & $12420 W$ & -0.8 & 82 & $\begin{array}{l}\text { West and } \\
\text { McCrumb, } 1988 .\end{array}$ \\
\hline Pt. Grenville & $4718 \mathrm{~N}$ & $12415 W$ & -0.4 & 82 & $\begin{array}{l}\text { West and } \\
\text { McCrumb, } 1988 .\end{array}$ \\
\hline $\begin{array}{l}\text { Average } \\
\text { uplift }\end{array}$ & $\begin{array}{l}4800 \mathrm{~N} \\
4500 \mathrm{~N}\end{array}$ & $\begin{array}{l}12430 \mathrm{~W} \\
12330 \mathrm{~W}\end{array}$ & $-0.4 \pm 0.2$ & 82 & $\begin{array}{l}\text { West and } \\
\text { McCrumb, } 1988 .\end{array}$ \\
\hline Grays Harbor & $4650 \mathrm{~N}$ & $12410 \mathrm{~W}$ & $1-2$ & 6.0 & $\begin{array}{l}\text { Phipps and } \\
\text { Peterson, } 1989 .\end{array}$ \\
\hline Netarts Bay & $4527 \mathrm{~N}$ & $12356 \mathrm{~W}$ & $1.1-1.3$ & $3.3-3.8$ & $\begin{array}{l}\text { Darienzo and } \\
\text { Peterson, } 1990 .\end{array}$ \\
\hline $\begin{array}{l}\text { Siletz Bay- } \\
\text { Otter Rock }\end{array}$ & $4450 \mathrm{~N}$ & $12400 \mathrm{~W}$ & -0.18 & 80 & Kelsey et al., 1996. \\
\hline $\begin{array}{l}\text { Otter Rock- } \\
\text { Yaquina Bay }\end{array}$ & $4439 \mathrm{~N}$ & $12404 \mathrm{~W}$ & -0.67 & $80-105$ & Kelsey et al., 1996. \\
\hline $\begin{array}{l}\text { South of } \\
\text { Yaquina Bay }\end{array}$ & $4430 N$ & $12404 \mathrm{~W}$ & -0.12 & 105 & Kelsey et al., 1996. \\
\hline $\begin{array}{l}\text { Central } \\
\text { Oregon coast }\end{array}$ & $\begin{array}{l}4500 \mathrm{~N} \\
4430 \mathrm{~N}\end{array}$ & $\begin{array}{l}12400 \mathrm{~W} \\
12400 \mathrm{~W}\end{array}$ & -0.34 & $80-125$ & Kelsey et al., 1994. \\
\hline
\end{tabular}


Table 1. Continued..

\begin{tabular}{|c|c|c|c|c|c|}
\hline Locality & Latitude & Longitude & $\begin{array}{l}\text { Land Motion } \\
\mathrm{mm} / \mathrm{yr}\end{array}$ & $\begin{array}{l}\text { Period } \\
10^{3} \text { yrs }\end{array}$ & References \\
\hline $\begin{array}{l}\text { Central } \\
\text { Oregon coast }\end{array}$ & $\begin{array}{l}4430 \mathrm{~N} \\
4400 \mathrm{~N}\end{array}$ & $\begin{array}{l}12400 \mathrm{~W} \\
12400 \mathrm{~W}\end{array}$ & -0.05 & $80-125$ & Kelsey et al., 1994. \\
\hline $\begin{array}{l}\text { Central } \\
\text { Oregon coast }\end{array}$ & $\begin{array}{l}4400 N \\
4330 N\end{array}$ & $\begin{array}{l}12400 \mathrm{~W} \\
12415 \mathrm{~W}\end{array}$ & -0.03 & $80-125$ & Kelsey et al., 1994. \\
\hline $\begin{array}{l}\text { Central } \\
\text { Oregon coast }\end{array}$ & $\begin{array}{l}4330 \mathrm{~N} \\
43 \mathrm{OON}\end{array}$ & $\begin{array}{l}12415 \mathrm{~W} \\
12430 \mathrm{~W}\end{array}$ & -0.23 & $80-125$ & Kelsey et al., 1994. \\
\hline $\begin{array}{l}\text { Central } \\
\text { Oregon coast }\end{array}$ & $\begin{array}{l}4300 \mathrm{~N} \\
4230 \mathrm{~N}\end{array}$ & $\begin{array}{l}12430 \mathrm{~W} \\
12430 \mathrm{~W}\end{array}$ & -0.26 & $80-125$ & Kelsey et al., 1994. \\
\hline $\begin{array}{l}\text { Central } \\
\text { Oregon coast }\end{array}$ & $\begin{array}{l}4230 \mathrm{~N} \\
42 \mathrm{OON}\end{array}$ & $\begin{array}{l}12430 \mathrm{~W} \\
12430 \mathrm{~W}\end{array}$ & -0.30 & $80-125$ & Kelsey et al., 1994. \\
\hline Cape Arago & $4319 N$ & $12424 \mathrm{~W}$ & $\begin{array}{l}-0.54 \text { to } \\
-0.7\end{array}$ & $80-105$ & $\begin{array}{l}\text { McInelly and } \\
\text { Kelsey, } 1990 .\end{array}$ \\
\hline Coquille Point & $4307 \mathrm{~N}$ & $12426 \mathrm{~W}$ & -0.75 & 80 & Muhs et al., 1990. \\
\hline Cape Blanco & $4250 \mathrm{~N}$ & $12434 W$ & -1.10 & $80-105$ & Muhs et al., 1990. \\
\hline Cape Ferralo & $4205 \mathrm{~N}$ & $12420 \mathrm{~W}$ & -0.76 & $80-125$ & $\begin{array}{l}\text { Kelsey and } \\
\text { Bockheim, } 1994 .\end{array}$ \\
\hline Harbor & $4201 \mathrm{~N}$ & $12515 \mathrm{~W}$ & -0.12 & 125 & $\begin{array}{l}\text { Kelsey and } \\
\text { Bockheim, } 1994 .\end{array}$ \\
\hline $\begin{array}{l}\text { Cape } \\
\text { Mendocino }\end{array}$ & $4030 \mathrm{~N}$ & $12415 \mathrm{~W}$ & $\begin{array}{l}-2.9 \text { to } \\
-3.4\end{array}$ & 100 & $\begin{array}{l}\text { Merritts and Bull, } \\
1989 .\end{array}$ \\
\hline $\begin{array}{l}\text { Randall-Big } \\
\text { Flat }\end{array}$ & $4015 \mathrm{~N}$ & $12413 W$ & -4.0 & 100 & $\begin{array}{l}\text { Merritts and Bull, } \\
1989 .\end{array}$ \\
\hline Pt. Delgada & $4000 \mathrm{~N}$ & $12400 \mathrm{~W}$ & -1.2 & 100 & $\begin{array}{l}\text { Merritts and Bull, } \\
1989 .\end{array}$ \\
\hline $\begin{array}{l}\text { Bruhel Point- } \\
\text { Fort Bragg }\end{array}$ & $3930 \mathrm{~N}$ & $12345 W$ & -0.4 & 100 & $\begin{array}{l}\text { Merritts and Bull, } \\
1989 .\end{array}$ \\
\hline Point Cabrillo & $3915 \mathrm{~N}$ & $12345 \mathrm{~W}$ & -0.31 & 102 & Lajoie et al., 1991. \\
\hline
\end{tabular}


Table 1.

Continued..

\begin{tabular}{|c|c|c|c|c|c|}
\hline Locality & Latitude & Longitude & $\begin{array}{l}\text { Land Motion } \\
\mathrm{mm} / \mathrm{yr}\end{array}$ & $\begin{array}{l}\text { Period } \\
10^{3} \mathrm{yrs}\end{array}$ & References \\
\hline Point Arena & $3856 \mathrm{~N}$ & $12345 \mathrm{~W}$ & $\begin{array}{l}-0.35 \text { to } \\
-0.52\end{array}$ & 80 & Muhs et al., 1990. \\
\hline $\begin{array}{l}\text { Petaluma } \\
\text { marsh }\end{array}$ & $3805 \mathrm{~N}$ & $12230 \mathrm{~W}$ & 1.5 & $1.5-2.0$ & Byrne et al., 1994. \\
\hline $\begin{array}{l}\text { North San } \\
\text { Francisco } \\
\text { Bay }\end{array}$ & $3740 \mathrm{~N}$ & $12230 W$ & 1.5 & 7.0 & Wells et al., 1994. \\
\hline $\begin{array}{l}\text { Greyhound } \\
\text { Rock }\end{array}$ & $3700 \mathrm{~N}$ & $12205 W$ & -0.25 & 124 & Lajoie et al., 1991 \\
\hline Molino Creek & $3659 \mathrm{~N}$ & $12204 \mathrm{~W}$ & -0.21 & 124 & Lajoie et al., 1991 \\
\hline Majors Creek & $3658 \mathrm{~N}$ & $12203 \mathrm{~W}$ & -0.17 & 124 & Lajoie et al., 1991 \\
\hline $\begin{array}{l}\text { Monterey } \\
\text { Peninsula }\end{array}$ & $3635 \mathrm{~N}$ & $12157 \mathrm{~W}$ & $\begin{array}{l}-0.16 \text { to } \\
-0.20\end{array}$ & 103 & McKittrick, 1988. \\
\hline San Simeon & $3539 \mathrm{~N}$ & $12111 \mathrm{~W}$ & $\begin{array}{l}-0.12 \text { to } \\
-0.27\end{array}$ & 120 & $\begin{array}{l}\text { Hanson et al., } \\
1994 .\end{array}$ \\
\hline Cayucos & $3528 \mathrm{~N}$ & $12054 W$ & 0.0 & 120 & $\begin{array}{l}\text { Hanson et al., } \\
1994 .\end{array}$ \\
\hline Morro Bay & $3524 \mathrm{~N}$ & $12050 W$ & $<0.0$ & 120 & $\begin{array}{l}\text { Hanson et al., } \\
1994 .\end{array}$ \\
\hline $\begin{array}{l}\text { Point } \\
\text { Buchon }\end{array}$ & $3515 \mathrm{~N}$ & $12055 W$ & $\begin{array}{l}-0.19 \text { to } \\
-0.20\end{array}$ & 120 & $\begin{array}{l}\text { Hanson et al., } \\
1994 .\end{array}$ \\
\hline $\begin{array}{l}\text { Point San } \\
\text { Luis }\end{array}$ & $3512 \mathrm{~N}$ & $12050 \mathrm{~W}$ & -0.06 & 120 & $\begin{array}{l}\text { Hanson et al., } \\
1994 .\end{array}$ \\
\hline Shell Beach & $3512 \mathrm{~N}$ & $12040 W$ & -0.11 & 120 & $\begin{array}{l}\text { Hanson et al., } \\
1994 .\end{array}$ \\
\hline $\begin{array}{l}\text { Pismo } \\
\text { Beach-Arroyo } \\
\text { Grande }\end{array}$ & $3510 \mathrm{~N}$ & $12037 \mathrm{~W}$ & -0.12 & 120 & $\begin{array}{l}\text { Hanson et al., } \\
1994 .\end{array}$ \\
\hline Goleta & $3426 \mathrm{~N}$ & $11950 \mathrm{~W}$ & $\begin{array}{l}-0.4 \text { to } \\
-4.1\end{array}$ & $40-60$ & Lajoie et al., 1982. \\
\hline
\end{tabular}


Table 1.

Continued..

\begin{tabular}{|c|c|c|c|c|c|}
\hline Locality & Latitude & Longitude & $\begin{array}{l}\text { Land Motion } \\
\mathrm{mm} / \mathrm{yr}\end{array}$ & $\begin{array}{l}\text { Period } \\
10^{3} \text { yrs }\end{array}$ & References \\
\hline $\begin{array}{l}\text { Goleta-- } \\
\text { Point } \\
\text { Conception }\end{array}$ & $3426 \mathrm{~N}$ & $12015 W$ & $\begin{array}{l}-0.4 \text { to } \\
-0.6\end{array}$ & $85-120$ & Lajoie et al., 1982. \\
\hline $\begin{array}{l}\text { Carpinteria-- } \\
\text { Pitas Point }\end{array}$ & $3425 \mathrm{~N}$ & $11931 W$ & $\begin{array}{l}0.0 \text { to } \\
-10.0\end{array}$ & $40-60$ & Lajoie et al., 1982. \\
\hline Ventura & $3415 \mathrm{~N}$ & $11918 W$ & $\begin{array}{l}-1.7 \text { to } \\
-2.0\end{array}$ & $85-105$ & Lajoie et al., 1982. \\
\hline $\begin{array}{l}\text { Pacific } \\
\text { Palisades }\end{array}$ & $3404 \mathrm{~N}$ & $11830 \mathrm{~W}$ & -0.7 & 120 & Lajoie et al., 1982. \\
\hline Point Dume & $3400 N$ & $11845 W$ & -0.2 & 120 & Lajoie et al., 1982. \\
\hline Los Angeles & $3355 \mathrm{~N}$ & $11815 W$ & 1.5 . & $10^{6}$ & Mayer, 1987. \\
\hline $\begin{array}{l}\text { Venice Plain } \\
\text { Redondo } \\
\text { Beach-- } \\
\text { El Segundo }\end{array}$ & $3350 \mathrm{~N}$ & $11821 \mathrm{~W}$ & -0.19 & 124 & Lajoie et al., 1991. \\
\hline $\begin{array}{l}\text { San Pedro, } \\
\text { Cabrillo Fault }\end{array}$ & $3345 \mathrm{~N}$ & $11819 W$ & -0.33 & 120 & Muhs et al., 1989. \\
\hline San Pedro & $3344 \mathrm{~N}$ & $11820 W$ & -0.21 & 124 & Lajoie et al., 1991. \\
\hline $\begin{array}{l}\text { Laguna } \\
\text { Beach }\end{array}$ & $3332 N$ & $11745 W$ & -0.02 & 125 & Shlemon, 1979. \\
\hline Dana Point & $3328 \mathrm{~N}$ & $11740 W$ & -0.26 & 125 & Shlemon, 1979. \\
\hline San Onofre & $3324 \mathrm{~N}$ & $11734 \mathrm{~W}$ & -0.10 & 125 & Shlemon, 1979. \\
\hline $\begin{array}{l}\text { San Nicolas } \\
\text { Island }\end{array}$ & $3315 \mathrm{~N}$ & $11930 W$ & -0.22 & 120 & Muhs et al., 1987. \\
\hline $\begin{array}{l}\text { San Onofre } \\
\text { Bluff-Torrey } \\
\text { Pines }\end{array}$ & $3257 \mathrm{~N}$ & $11715 W$ & $\begin{array}{l}-0.19 \text { to } \\
-0.21\end{array}$ & 118 & Lajoie et al., 1991. \\
\hline $\begin{array}{l}\text { San Clemente } \\
\text { Island }\end{array}$ & $3255 \mathrm{~N}$ & $11830 W$ & -0.13 & 127 & $\begin{array}{l}\text { Kennedy et al., } \\
1995 .\end{array}$ \\
\hline
\end{tabular}


Table $1 . \quad$ Concluded.

\begin{tabular}{llllll}
\hline Locality & Latitude & Longitude & $\begin{array}{l}\text { Land Motion } \\
\mathrm{mm} / \mathrm{yr}\end{array}$ & $\begin{array}{l}\text { Period } \\
10^{3} \mathrm{yrs}\end{array}$ & References \\
\hline & & & & & \\
Soledad Mt. & $3250 \mathrm{~N}$ & $11716 \mathrm{~W}$ & -0.34 & 118 & Lajoie et al., 1991. \\
Point Loma & $3240 \mathrm{~N}$ & $-11715 \mathrm{~W}$ & -0.21 & 118 & Lajoie et al., 1991. \\
\hline
\end{tabular}

Table 2. Relative sea-level trends, U.S. West Coast, $\mathrm{mm} / \mathrm{yr}$.

\begin{tabular}{lcccc}
\hline STATION & LATTUDE & LONGITUDE & SLYR & SLR \\
& & & & \\
\hline & & & & \\
Friday Harbor & $4833 \mathrm{~N}$ & 123 00W & 58 & 1.12 \\
Neah Bay & $4822 \mathrm{~N}$ & $12437 \mathrm{~W}$ & 56 & -1.61 \\
Port Townsend & 48 07N & $12245 \mathrm{~W}$ & 21 & 1.98 \\
Seattle & $4736 \mathrm{~N}$ & 122 20W & 96 & 2.01 \\
Astoria & $4613 \mathrm{~N}$ & $12346 \mathrm{~W}$ & 68 & -0.60 \\
South Beach & $4438 \mathrm{~N}$ & 124 03W & 22 & 4.39 \\
Crescent City & $4145 \mathrm{~N}$ & $12412 \mathrm{~W}$ & 60 & -0.72 \\
San Francisco & $3748 \mathrm{~N}$ & 122 28W & 140 & 1.37 \\
Alameda & $3746 \mathrm{~N}$ & $12218 \mathrm{~W}$ & 54 & 0.77 \\
Monterey & $3636 \mathrm{~N}$ & $12153 \mathrm{~W}$ & 21 & 3.11 \\
Port San Luis & $3510 \mathrm{~N}$ & $12045 \mathrm{~W}$ & 45 & 1.24 \\
Santa Monica & 34 01N & $11830 \mathrm{~W}$ & 53 & 1.98 \\
Los Angeles & $3343 \mathrm{~N}$ & $11816 \mathrm{~W}$ & 70 & 0.85 \\
Newport Beach & $3336 \mathrm{~N}$ & $11753 \mathrm{~W}$ & 35 & 1.65 \\
La Jolla & $3252 \mathrm{~N}$ & $11715 \mathrm{~W}$ & 65 & 2.42 \\
San Diego & $3243 \mathrm{~N}$ & $11710 \mathrm{~W}$ & 87 & 2.24 \\
& & & & \\
Data from Permanent Service for Mean Sea Level, Sept. 1996. & & \\
& & & & \\
\hline
\end{tabular}


Figure 1. Information on uplift rates, in $\mathrm{mm} / \mathrm{yr}$ along the West Coast from various sources listed in Table 1.

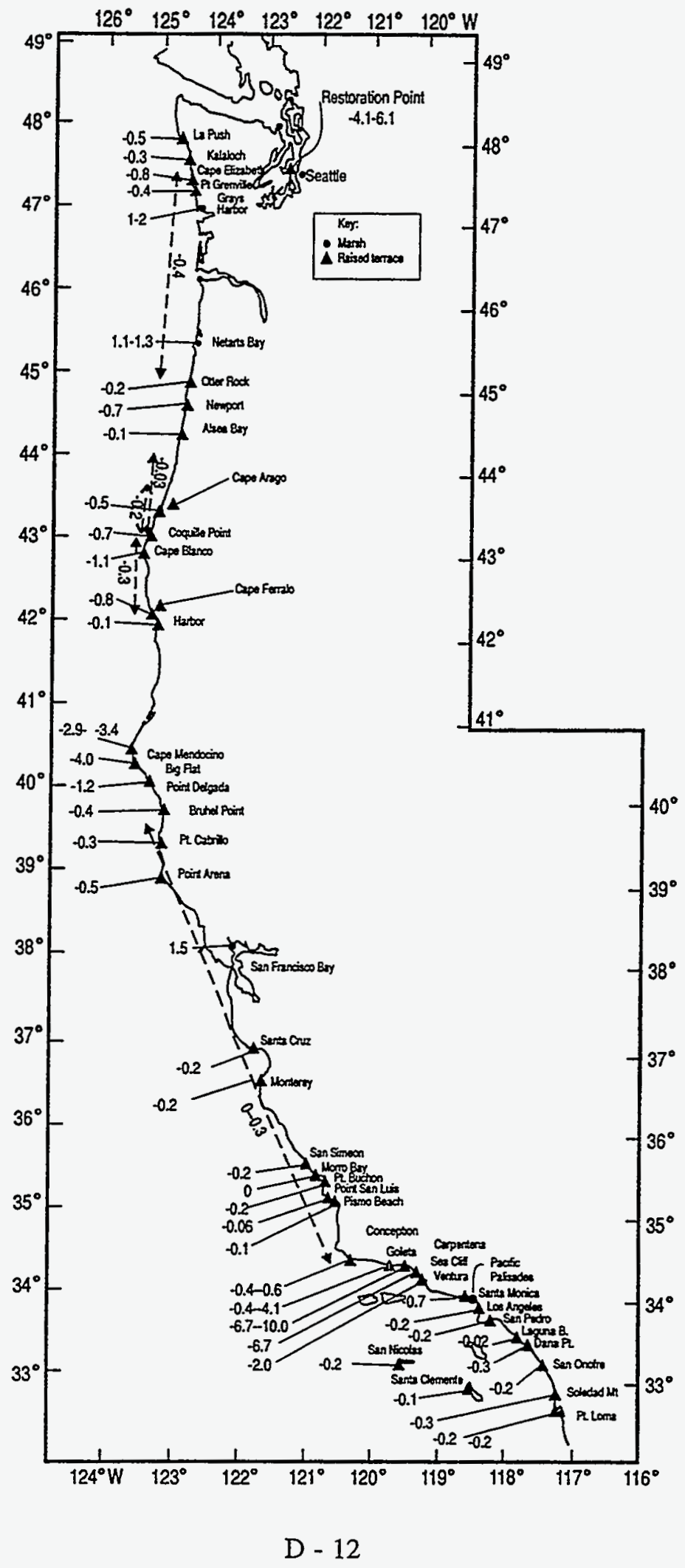


Figure 2. Relative sea-level trends ( $\mathrm{mm} / \mathrm{yr})$, for each of the 16 tide-gauge stations listed in Table 2 .

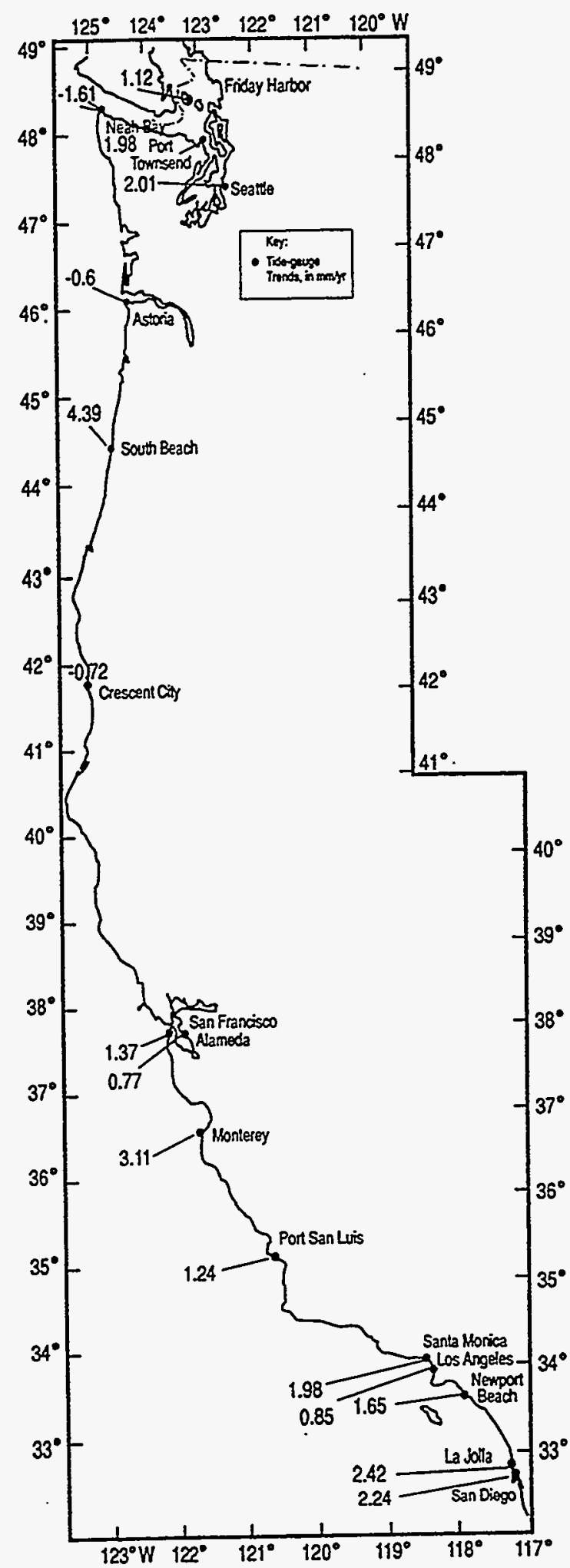

D -13 
APPENDIX E: REPRINT OF PERTINENT LITERATURE reprint removed. 


\section{Internal Distribution}

1-5. T. W. Beaty

6. T. A. Boden

7. M. D. Burtis

8. R. M. Cushman

9. S. G. Hildebrand

10. G. K. Jacobs

11. S. V. Jennings

12. S. B. Jones

13. D. P. Kaiser

14. P. Kanciruk

15. J. M. Loar
16. T. E. Myrick

17. D. E. Reichle

18. D. E. Shepherd

19. D. S. Shriner

20. L. D. Voorhees

21-120. CDIAC

121. Central Research Library

122-124. ESD Library

125-126. Laboratory Records Department

127. Laboratory Records Department ORNL-RC

128. Y-12 Technical Library

\section{External Distribution}

129. S. S. Alexander, Pennsylvania State University, Department of Geosciences, 537 Deike Building, State College, PA 16802

130. R. Bidigare, University of Hawaii, Department of Oceanography, 1000 Pope Road, Honolulu, HI 96822

131. R. M. Bierbaum, Office of Science and Technology Policy, 443 Old Executive Office Bldg., 17th and Pennsylvania Avenue NW, Washington, D.C. 20500

132. C. Boelcke, P.S.S., United Nations Environment Program, P.O. Box 30552, Nairobi, Kenya

133. P. G. Brewer, Monterey Bay Aquarium Research Institute, P.O. Box 628, 7700 Sandholt Road, Moss Landing, CA 95039

134. M. Broido, Department of Energy, Office of Biological and Environmental Research, Environmental Sciences Division, ER-74, 19901 Germantown Road, Germantown, MD 20874

135. L. Brugmann, Stockholm University, Department of Geology and Geochemistry, S-106 91 Stockholm, Sweden

136. H. Croze, P.S.S., United Nations Environment Program, P.O. Box 30552, Nairobi, Kenya

137. E. G. Cumesty, ORNL Site Manager, Department of Energy, Oak Ridge National Laboratory, P.O. Box 2008, Oak Ridge, TN 37831-6269 
138. G. Daneri, CEA Universidad del Mar, Dept. de Oceanografia y Biologia Pesquera, Amunaategui 1838, Vina Del Mar, Chile

139-143. R. C. Daniels, Shorelands and Water Resources Program, Water Division, Department of Ecology, Olympia, WA 98504

144. Database Section, National Institute for Environmental Studies, Center for Global Environmental Research, 16-2 Onogawa, Tsukuba, Ibaraki 305, Japan

145. J. W. Elwood, Department of Energy, Office of Biological and Environmental Research, Environmental Sciences Division, ER-74, 19901 Germantown Road, Germantown, MD 20874

146. Energy Library (HR-832.1/GTN), Department of Energy, Office of Administration and Management, G-034, Washington, D. C. 20585

147. Energy Library (HR-832.2/WAS), Department of Energy, Office of Administration and Management, GA-138 Forrestal Building, Washington, D. C. 20585

148. G. Esser, Justus-Liebig-University, Institute for Plant Ecology, Heinrich-Buff-Ring 38, D-35392 Giessen, Germany

149. W. Ferrell, Department of Energy, Office of Biological and Environmental Research, Environmental Sciences Division, ER-74, 19901 Germantown Road, Germantown, MD 20874

150. W. Gardner, Texas A \& M University, Department of Oceanography, College Station, TX 77843

151. J.-P. Gattuso, Observatoire Oceanologique Europeen, Avenue Saint-Martin, MC-98000, Monaco

152-156. V. M. Gornitz, National Aeronautics and Space Administration, Goddard Institute for Space Studies, 2880 Broadway, New York, NY 10025

157. D. O. Hall, University of London, Division of Biosphere Sciences, King's College London, Campden Hill Road, London W8 7AH, United Kingdom

158. A. Harashima, Japan Environment Agency, Global Environmental Research Division, 16-2 Onogawa, Tsukuba, Ibaraki 305, Japan

159. A. Hittelman, WDC-A for Solid Earth Geophysics, NOAA Code E/GC1, 325 Broadway, Boulder, CO 80303

160. H. Hodgson, British Library, Boston Spa, DSC, Special Acquisitions, Wetherby, West Yorkshire, LS23 7BQ, United Kingdom 
161. Huasheng Hong, Xiamen University, Environmental Science Research Center, Post Code 361005, Mail Box 1085, Xiamen, Fujian, Peoples Republic China

162. C. A. Hood, GCRIO, 2250 Pierce Road, Bay City, MI 48710

163. J. C. Houghton, Department of Energy, Office of Biological and Environmental Research, Environmental Sciences Division, ER-74, 19901 Germantown Road, Germantown, MD 20874

164. G. Kaminsky, Washington Department of Ecology, P.O. Box 47600, Olympia, WA 98504-7600

165. T. R. Karl, National Climatic Data Center, 151 Patton Avenue, Federal Building, Room 516E, Asheville, NC 28801

166. S. Kempe, Schnittspahnstr. 9, D-64287 Darmstadt, Germany

167. K.-R. Kim, Seoul National University, Dept. of Oceanology, Seoul 151-7442, Korea

168. J. C. Klink, Miami University, Department of Geography, 217 Shideler Hall, Oxford, $\mathrm{OH} 45056$

169. K. Lajoie, U. S. Geological Survey, 345 Middlefield Road, MS870, Menlo Park, CA 94025

170. D. T. Lauer, EROS Data Center, U.S. Geological Survey, Sioux Falls, SD 57198

171. P. Lunn, Department of Energy, Office of Biological and Environmental Research, Environmental Sciences Division, ER-74, 19901 Germantown Road, Germantown, MD 20874

172. T. H. Mace, U.S. Environmental Protection Agency, National Data Processing Division, 79 TW Alexander Drive, Bldg. 4201, MD-34, Durham, NC 27711

173. J. J. McCarthy, Harvard University, Museum of Comparative Zoology, 26 Oxford Street, Cambridge, MA 02138

174. M. C. McCracken, Director, Office of the U.S. Global Change Research Program, Code YS-1, 300 E. Street, SW, Washington, D. C. 20546

175. F. J. Millero, University of Miami, RSMAS, 4600 Rickenbacker Causeway, Miami, FL 33149

176. R. E. Munn, University of Toronto, Institute for Environmental Studies, Haultain Building, 170 College Street, Toronto, Ontario M5S 1A4, Canada 
177. S. Nishioka, National Institute for Environmental Studies, Global Environment Research Division, 16-2 Onogawa, Tsukuba, Ibaraki 305, Japan

178. J. R. Oh, Korea Ocean Research and Development Institute, Chemical Oceanography Division, An San P.O. Box 29, Seoul 4325-600, Korea

179. C. Olsen, Office of Biological and Environmental Research, Environmental Sciences Division, ER-74, Department of Energy, 19901 Germantown Road, Germantown, MD 20874

180. B. Parra, Department of Energy, Office of Biological and Environmental Research, Environmental Sciences Division, ER-74, 19901 Germantown Road, Germantown, MD 20874

181. A. Patrinos, Department of Energy, Office of Biological and Environmental Research, Environmental Sciences Division, ER-74, 19901 Germantown Road, Germantown, MD 20874

182. G. R. Priest, Oregon Department of Geology and Mineral Industries, Suite 965, $800 \mathrm{NE}$ Oregon St. \#28, Portland, OR 97232

183. T.-H. Peng, NOAA/AOML, Ocean Chemistry Division, 4301 Rickenbacker Causeway, Miami, FL 33149

184. S. Railsback, PE, Lang, Railsback \& Associates, Water Resource Research and Management, 250 California Avenue, Arcata, CA 95521

185. R. Y. Rand, USDA, Global Change Data and Information Management, 10301 Baltimore Boulevard, Beltsville, MD 20705

186. C. Reimers, Rutgers University, Institute of Marine and Coastal Sciences, P.O. Box 231, New Brunswick, NJ 08903

187. M. R. Riches, Department of Energy, Office of Biological and Environmental Research, Environmental Sciences Division, ER-74, 19901 Germantown Road, Germantown, MD 20874

188. J. L. Sarmiento, Princeton University, Atmospheric and Oceanic Sciences Program, P.O. Box CN710, Sayre Hall, Princeton, NJ 08544

189. G. S. Sayler, The University of Tennessee, Center for Environmental Biotechnology, 676 Dabney Hall, Knoxville, TN 37996-1605

190. M. H. C. Stoll, Netherlands Institute for Sea Research, Dept. MCG, P. O. Box 59, 1790 Ab den Burg-Texel, The Netherlands 
191. E. T. Sundquist, U.S. Geological Survey, Quissett Campus, Branch of Atlantic Marine Geology, Woods Hole, MA 02543

192. T. Takahashi, Columbia University, Lamont-Doherty Earth Observatory, Climate, Environment, and Ocean Division, Rt. 9W, Palisades, NY 10964

193. J. A. Taylor, Australian National University, CRES, GPO Box 4, Canberra, ACT 0200, Australia

194. J. R. G. Townshend, University of Maryland, Dept. of Geography, 1113 Lefrak Hall, College Park, MD 20742

195. J. Tucker, Marine Biological Laboratory, Woods Hole, MA 02543

196. D. W. R. Wallace, Brookhaven National Laboratory, Oceanographic and Atmospheric Sciences Division, P.O. Box 5000, Upton, NY 11973

197. C. Watts, National Oceanic and Atmospheric Administration, Central Library, 1315 East-West Highway, 2nd Floor, SSMC 3, Silver Spring, MD 20910

198. F. Webster, University of Delaware, College of Marine Studies, Lewes, DE 19958

199. A. Winter, University of Puerto Rico, Department of Marine Sciences, Puerto Rico State Climate Office, P.O. Box 5000, Mayaguez, PR 00681

200. C. S. Wong, Government of Canada, Institute of Ocean Sciences, P.O. Box 6000, 9860 West Saanich Road, Sidney, BC V8L 4B2, Canada

201. M. Yamamuro, Geological Survey of Japan, Marine Geology Department, 1-1-3 Higashi, Tsukuba, Ibaraki 305, Japan

202. Y. Yosuoka, National Institute for Environmental Studies, Center Global Environment Research, 16-2 Onogawa, Tsukuba, Ibaraki 305, Japan

203. Office of Scientific and Technical Information, P. O. Box 62, Oak Ridge, TN 37831 